\author{
UNIVERSIDADE DE SÃO PAULO \\ FACULDADE DE FILOSOFIA, LETRAS E CIÊNCIAS HUMANAS \\ DEPARTAMENTO DE HISTÓRIA \\ PROGRAMA DE PÓS-GRADUAÇÃO EM HISTÓRIA ECONÔMICA
}

A cosmologia científica na obra de José da Silva Lisboa

Daniel de Lara Oliveira

São Paulo

2020

VERSÃO CORRIGIDA 


\author{
UNIVERSIDADE DE SÃO PAULO \\ FACULDADE DE FILOSOFIA, LETRAS E CIÊNCIAS HUMANAS \\ DEPARTAMENTO DE HISTÓRIA \\ PROGRAMA DE PÓS-GRADUAÇÃO EM HISTÓRIA ECONÔMICA
}

\title{
A cosmologia científica na obra de José da Silva Lisboa
}

Daniel de Lara Oliveira

Tese apresentada ao Programa de Pós-Graduação em História Econômica da Faculdade de Filosofia, Letras e Ciências Humanas da Universidade de São Paulo para obtenção do título de Doutor em História.

Orientadora: Prof. ${ }^{a}$ Dra. Sara Albieri

São Paulo

2020

VERSÃO CORRIGIDA 
Autorizo a reprodução e divulgação total ou parcial deste trabalho, por qualquer meio convencional ou eletrônico, para fins de estudo e pesquisa, desde que citada a fonte.

Catalogação na Publicação

Serviço de Biblioteca e Documentação

Faculdade de Filosofia, Letras e Ciências Humanas da Universidade de São Paulo

$048 \mathrm{C}$

Oliveira, Daniel de Lara

A cosmologia científica na obra de José da Silva Lisboa / Daniel de Lara Oliveira ; orientadora Sara Albieri. - São Paulo, 2020.

$160 \mathrm{f}$.

Tese (Doutorado) - Faculdade de Filosofia, Letras e Ciências Humanas da Universidade de São Paulo. Departamento de História. Área de concentração: História Econômica.

1. José da Silva Lisboa. 2. Filosofia Natural. 3. Iluminismo. 4. Economia Política. 5. Adam Smith. I. Albieri, Sara, orient. II. Título. 


\title{
ENTREGA DO EXEMPLAR CORRIGIDO DA DISSERTAÇÃO/TESE
}

\section{Termo de Ciência e Concordância do (a) orientador (a)}

\author{
Nome do (a) aluno (a): Daniel de Lara Oliveira
}

Data da defesa: 26 / 11 / 2020

Nome do Prof. (a) orientador (a): Sara Albieri

Nos termos da legislação vigente, declaro ESTAR CIENTE do conteúdo deste EXEMPLAR CORRIGIDO elaborado em atenção às sugestões dos membros da comissão Julgadora na sessão de defesa do trabalho, manifestando-me plenamente favorável ao seu encaminhamento e publicação no Portal Digital de Teses da USP.

São Paulo, 06 / 02 / 2021

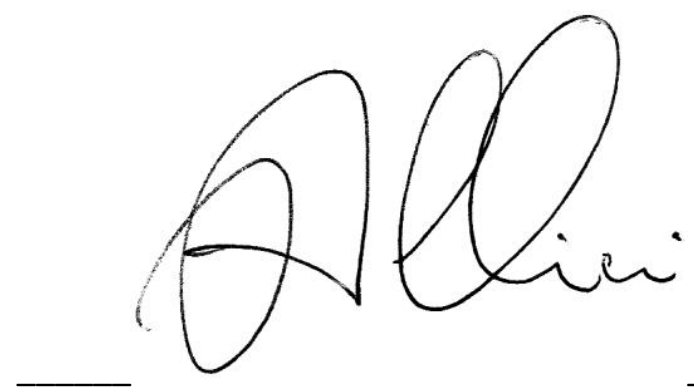

(Assinatura do (a) orientador 
À memória de meu tio, David de Lara, por me incentivar ao hábito e à satisfação de aprender. 


\section{Agradecimentos}

Como outrora na finalização do Mestrado, mais uma vez agradeço à Universidade de São Paulo, instituição pública de ensino, por tudo o que proporcionou à minha formação e a de tantos outros que aqui encontraram e continuam a encontrar possibilidades para a vivência acadêmica, o enriquecimento científico e cultural, necessários à toda esta nação.

À Professora Sara Albieri, antes de mais nada pelo amplo, necessário e perene apoio que já se estende há anos. Sou grato a cada uma das ocasiões nas quais fomentou meu ânimo em continuar a pesquisa, antes mesmo que eu pudesse verbalizar percalços de ordem diversa, todos minimizados com acuidade, precisão e rapidez que somente sua experiência, aliada a uma boa vontade sem par, seria capaz de conferir àqueles momentos. Sou grato pelo modo paciencioso que imprimiu em toda a orientação acadêmica, condição que em muito favoreceu a aproximação e a confiança necessárias para melhor encaminhamento da temática, metodologia, dúvidas acerca da abordagem, além das questões de ordem burocrática. De modo específico, agradeço também a disposição e dedicação em compreender a proposta da pesquisa, cujo estreito diálogo junto a temas da filosofia tornaram tal orientação indispensável. Serei sempre muito grato à Professora Sara Albieri.

Ao Professor Valdir Iusif Dainez, do Departamento de Economia da PUC-Campinas, pela disposição incondicional em colaborar na realização desta pesquisa, especialmente nos momentos de necessária aproximação à história do pensamento econômico. Sou grato às indicações bibliográficas, às orientações e esclarecimentos acerca da economia política, mas também e sobretudo pelo apoio e pela amizade construída. 
À minha mãe, pelo apoio e pela a preocupação, gestos silenciosos e sinceros, sempre indispensáveis. Apoio inestimável, diante do qual eu jamais estarei à altura de realizar um agradecimento condizente.

A muitos colegas de docência, pelo incentivo cotidiano e a disponibilidade em colaborar. Não seria possível mencionar todos esses apoiadores sem cometer injustiças, mas Álvaro Pietrobon e Neto Gazonato devem ser mencionados em reconhecimento ao horário em que me atenderam prontamente na reta final para a entrega deste material.

A meu caro amigo, Éder Marques Loyola, pelo recorrente e sincero incentivo prestado desde os anos de Graduação e Mestrado, quando ainda morávamos na USP, amizade que resistiu à distância e à escassez das prosas que a vida profissional acabou impondo. 


\section{Resumo}

A pesquisa identifica e analisa elementos da filosofia natural encontrados na obra de José da Silva Lisboa (1756 - 1835), com interesses voltados à compreensão acerca da importância de teorias e conceitos da ciência e da cultura iluminista a compor sua cosmologia. As análises estão voltadas sobretudo a compreender o modo com que elementos encontrados na filosofia natural proporcionaram a José da Silva Lisboa uma determinada visão de mundo e seu respectivo arcabouço conceitual, por ele assumido como um dos principais responsáveis pela coerência interna de sua obra, nos momentos em que se apropriou de teorias formuladas no cenário intelectual europeu, a partir das condições materiais europeias, projetando tal ideário ao cenário brasileiro e suas especificidades.

A pesquisa apresenta as linhas gerais da discussão historiográfica em torno da obra de José da Silva Lisboa, a fim de destacar a pertinência da problemática aqui sugerida. Em seguida, desenvolve análises acerca da relação entre cultura religiosa e cultura científica, busca compreender as relações entre moral religiosa, economia política e bem comum, finalizando com uma análise interessada no problema do progresso da riqueza, com reiterado destaque à recepção e apropriação realizadas por Silva Lisboa junto às ideias de Adam Smith e do chamado liberalismo econômico de modo geral. Atenta à presença de teorias, métodos e conceitos provenientes da filosofia natural na cosmologia desse autor, a pesquisa avalia a respectiva importância desse instrumental teórico e epistemológico na lógica interna, coerência e razoabilidade que Silva Lisboa pretendeu conferir à sua obra. 


\begin{abstract}
The research identifies and analyzes natural philosophy elements found in José da Silva Lisboa work (1756 - 1835), with interests aimed at the understanding about the importance of science theories and concepts and also the iluminist culture composing his cosmology. The analysis are mainly aimed at understanding the way in which elements found in natural philosophy provided José da Silva Lisboa with a determined worldview, which he assumed to be one of the main responsible for providing the internal coherence of his work, in the moments when he appropriated theories formulated in the european intellectual scenario, based on European material conditions, projecting such an ideal to the brazilian scenario.

The research presents the historiographical discussion general lines around José da Silva Lisboa work, in order to highlight the issue pertinence here suggested, developed in alanyses about the relation between religious culture and scientific culture; religious morality, political economy and the common good; ending with an analysis on the wealth matter progress, with repeated emphasis on the reception and appropriation of Adam Smith ideas and the economic liberalism done by Silva Lisboa. Attentive to the presence of theories, methods and concepts from natural philosophy in the cosmology of this author, the research assesses the respective importance of this theoretical and epistemological tool for the internal logic, coherence and reasonableness of his work, according to his understanding.
\end{abstract}




\section{ÍNDICE}

Introdução.

09

As fontes históricas: justificativas e métodos de abordagem.

34

Capítulo 1. Acerca de Silva Lisboa e seus escritos: inventários,

análises, discursos. Um balanço historiográfico.

46

Capítulo 2. O pensamento híbrido de José da Silva Lisboa. .71

Capítulo 3. Moral religiosa, economia política e bem comum. . .93

Discursos de síntese. Filosofia natural, moral e religião. .99

Os limites da síntese na projeção de uma sociedade. .106

Capítulo 4. A questão do desenvolvimento:

Dos universais teóricos aos particulares do caso brasileiro. 118

Considerações Finais. .143

Bibliografia. 154 


\section{Introdução}

O objetivo central desta pesquisa foi tomar a obra do luso-brasileiro, José da Silva Lisboa (1756 - 1835), para analisar a recepção, apropriação e uso de recursos de compreensão e explicação que, uma vez encontrados na filosofia natural, passaram a atuar em suas interpretações sobre a formação histórica brasileira e em suas reflexões acerca das possibilidades de desenvolvimento da nação. Analisar a cosmovisão de Silva Lisboa, com atenções ao que nela diz respeito a elementos encontrados na filosofia natural e sua devida importância na elaboração de uma obra de variada temática, de interesse mais destacado a aspectos ligados à política, à moral, à sociedade, à economia política. Trata-se de um estudo de caso voltado à obra daquele que viria a ser intitulado visconde de Cairu, publicada nas décadas iniciais do século XIX.

As análises serão motivadas pelo intento de compreender as especificidades históricas com que tal membro da elite letrada brasileira, contemporâneo das últimas décadas do Antigo Regime, se apropriou de teorias e conceitos originalmente formulados para o conhecimento da natureza, somando à sua visão de mundo elementos de uma cultura científica que empregou em seus estudos acerca do Brasil. O objetivo foi identificar e analisar questões que dizem respeito à história das ideias científicas, realizar uma pesquisa interessada na apropriação de uma dada racionalidade para a constituição de conhecimentos teóricos e práticos relacionados às ciências do homem então nascentes, em especial às ideias ligadas à economia política.

A cosmologia científica na obra de José da Silva Lisboa é resultado de uma pesquisa voltada a analisar os aspectos de uma racionalidade presente na cosmologia expressa por Silva Lisboa, uma vez que em boa medida ele teve a ciência de seus dias como importante fonte de orientação, cuja influência incidiu sobre suas abordagens teóricas e conceituais direcionadas à economia política, com os respectivos desdobramentos junto a temáticas hoje tratadas pela sociologia, antropologia, moral, geografia e história, dentre outras áreas, hoje delimitadas por suas especificidades de 
objeto e abordagem, outrora interligadas por uma visão de mundo mais interessada em generalizações a partir de discursos de síntese.

Voltar atenções a conceitos e ideários em geral, cujo trânsito se dá por meio de obras de pensamento, foi uma postura analítica já largamente empregada na dissertação de mestrado que precedeu este trabalho, oportunidade aquela na qual os estudos debruçaramse sobre a obra do português Luís António Verney, cuja conclusão foi apresentada também à Faculdade de Filosofia, Letras e Ciências Humanas da Universidade de São Paulo, sob título Ciência moderna e newtonianismo no projeto pedagógico de Luís António Verney. A escolha de tal problemática levou aquela pesquisa a resultados bastante satisfatórios, na medida em que foi possível observar e submeter à análise leituras e compreensões a que chegou um autor de cultura portuguesa a respeito de algumas proposições da ciência moderna em geral, assim como do pensamento newtoniano, de modo mais específico.

A aproximação de Verney, pensador tido de alguma forma como um representante da cultura ilustrada no cenário intelectual ibérico, ainda que católico convicto, membro da Ordem Oratoriana, junto a um universo de ideias preocupadas com a filosofia natural, marcado pela valorização da experiência, da observação e da matemática como instrumental de linguagem cada vez mais empregado, também foi esclarecedor a respeito de algumas das condições de recepção das ideias modernas nas universidades portuguesas, com destaque à Universidade de Coimbra, cuja reforma institucional ao menos em seu início seguiu diretrizes iluministas que tiveram a obra de Verney como via de apresentação ${ }^{1}$, talvez o principal veículo a ter orientado o chamado ecletismo ${ }^{2}$, postura intelectual que ali deveria ser implementada, sob os auspícios do Marquês de Pombal.

${ }^{1}$ Cf. CARVALHO, José Murilo. História Intelectual no Brasil: a retórica como chave de leitura. IN: Topoi. Rio de Janeiro, nº 1, pp. 132-133.

${ }^{2} \mathrm{O}$ chamado ecletismo pode ser notado na obra de Verney, membro da ordem religiosa dos oratorianos. Ainda no início do século XVIII, o movimento dos oratorianos estendeu-se ao campo da filosofia e da ciência. Entre muitos oratorianos adotou-se o ecletismo orgânico, movimento intelectual no qual o sistema aristotélico deixava de ser o único admitido pela Igreja e condizente com a fé católica, além de não mais encarar tudo o que fosse novo em filosofia como sendo sinônimo de erro. Segundo Sebastião da Silva Dias, os oratorianos não alcançaram êxito em relação ao ecletismo orgânico, porque não foram capazes de formular uma síntese entre filosofia aristotélica e filosofia moderna; porém, foram sempre mais compreensíveis aos modernos e por isso mais fecundos do que seus adversários, fazendo com que o termo peripatético, aos poucos, se tornasse uma classificação pejorativa voltada aos aristotélicos (cf. DIAS, 2006, p. 206). 
A Universidade de Coimbra, em pleno vigor do espírito implementado pela reforma pombalina, foi o ambiente intelectual no qual tornou-se Bacharel em Cânones e Filosofia o luso-brasileiro José da Silva Lisboa, posteriormente intitulado, em 1826, visconde de Cairu. Silva Lisboa é autor da obra submetida à análise neste momento, em alguma medida, quiçá em profunda medida, uma expressão da Universidade de Coimbra após a reforma encaminhada durante o ministério pombalino. Foi essa formação que Silva Lisboa trouxe consigo para o Brasil, explicitou em sua vasta obra, em sua atuação política como deputado e senador, em suas inúmeras reflexões acerca de um dos momentos mais efervescentes da história ocidental, enquanto crise geral do Antigo Regime, e da história brasileira, haja vista que aqueles anos antecederam a independência política da nação.

Daí a pertinência da escolha da obra de Silva Lisboa para esta pesquisa que esteve direcionada à obtenção do doutoramento. Trata-se de voltar as atenções para um pensador luso-brasileiro, autor de uma obra já bastante estudada, mas projetando à mesma novos problemas, inquirindo-a acerca dos elementos ligados à filosofia natural, muitas vezes de cunho ilustrado e mesmo newtoniano, presentes na cosmovisão desse dado autor em suas observações, análises e propostas relativas ao Brasil, realizadas em um período de transição, partindo da condição de colônia, pertencente ao império português, para a de nação independente. O interesse dos estudos deixou de estar voltado a um autor português e passou a projetar esforços sobre a produção intelectual de um luso-brasileiro, sem com isso perder de vista o contexto intelectual, cuja problemática ligada ao ideário e aos conceitos apreendidos junto à filosofia natural ainda estavam presentes, embora projetados a um leque muito diversificado de interesses.

Pesquisadora da obra de Silva Lisboa, a historiadora Tereza Cristina Kirschner comenta de modo geral os resultados da passagem de estudantes provenientes das colônias pelo ambiente letrado de Coimbra.

... Embora a reforma da Universidade de Coimbra não tenha atingido todos objetivos previstos nos estatutos, deve-se reconhecer sua influência profunda e duradoura na mentalidade dos estudantes formados nas novas diretrizes de ensino. A atuação de muitos funcionários régios egressos da universidade reformada revela a assimilação dos princípios iluministas do direito e a intenção de aplicá-los. E a introdução do ensino de filosofia natural foi um fator que estimulou a pesquisa e a exploração dos recursos naturais do império português (KIRSCHNER, 2009, 37). 
Silva Lisboa é um exemplo dentre os estudantes de Coimbra, cuja formação exerceu em sua mentalidade o que a historiadora chamou de profunda e duradoura influência. Além dos estudos em Direito e em filosofia natural, esta enquanto instrumental para melhor aproveitamento do potencial da colônia, sobretudo seus recursos naturais, na obra de Silva Lisboa é possível notar que o conceitual aprendido junto à ciência dos modernos imprimiu ali uma visão de mundo que, se não determina, em muito influencia suas observações e análises a respeito dos mais variados aspectos da vida social, econômica, política e cultual. A filosofia natural exerce na cosmovisão de Silva Lisboa uma dada orientação; trata-se de um ideário, um acervo conceitual que esta pesquisa submeteu à análise.

Sendo assim, embora não de modo necessário, este trabalho em alguma medida retoma interesses que motivaram a dissertação de mestrado, pois volta-se à obra de um luso-brasileiro, estudado em uma Universidade de Coimbra já reformada sob orientação ilustrada, na qual a filosofia natural exerceu importante papel. Uma vez reconhecidas as intenções práticas de muitos dos estudos ali realizados, com especial menção às demandas por melhor exploração dos recursos da colônia, é possível notar que a filosofia natural também exerceu sobre os espíritos dos jovens estudantes de Coimbra uma influência mais geral, um modo de observar e interpretar o mundo em que viviam, e que pode ser investigado pela história intelectual. Trata-se portanto de um vínculo estabelecido não somente pela temática, mas pela abordagem através da qual pretende-se explorar as fontes históricas selecionadas.

Também há estreitos laços a aproximar as pesquisas de mestrado e doutorado, se levado em conta o fato de que é possível notar na obra de Silva Lisboa muitos aspectos do projeto que Luís António Verney desejava e trabalhou para que fosse levado à Universidade de Coimbra. Dentre os quais a dissertação de mestrado tomou para si a adoção e implementação dos estudos da então chamada ciência moderna, a qual tinha a física newtoniana como uma espécie de paradigma. A obra de Silva Lisboa expressa resultados daquele projeto que podem ser observados a partir de leituras iniciais, embora uma compreensão mais apurada tenha exigido devida profundidade, o que se pretende em alguma medida ter sido alcançado aqui a partir das análises de fonte apresentadas nas páginas subsequentes. Além da temática e da abordagem, este seria um vínculo entre 
autores de um mesmo contexto intelectual, aproximados pelas ideias e possíveis influências do projeto de Verney sobre a formação de Silva Lisboa.

Por fim, a breve apresentação dos vínculos entre os dois momentos da pósgraduação pode incluir um elemento mais específico da cultura portuguesa: o catolicismo. Luís António Verney e Silva Lisboa dedicaram-se à elaboração de uma obra de volume considerável, na qual a religiosidade católica esteve presente de modo significativo. Se a filosofia natural ocupou lugar central nas análises apresentadas na dissertação de mestrado e desta vez na tese de doutorado, a religiosidade dos autores cujas obras foram objetos de interesse não permite desconsiderar esse aspecto. Verney e Silva Lisboa escreveram suas respectivas obras sem jamais perderem de vista o horizonte do catolicismo a servir de orientação às suas reflexões acerca da moral. A filosofia natural compartilhada por ambos os autores não poderia de modo algum contradizer a fé católica, muito menos afastar-se de uma fé monoteísta e cristã. Este último seria um vínculo estabelecido por um importante elemento da cultura em que estiveram inseridos os autores estudados.

O destaque dos vínculos entre pesquisas de diferentes etapas da pós-graduação não pretende afirmar que a investigação agora apresentada teve, de modo exclusivo ou mesmo destacado, a pretensão de compreender a recepção e identificar o diálogo entre os autores e seus respectivos ideários. As abordagens a respeito da recepção ou mesmo do diálogo entre a obra de Verney e a de Silva Lisboa estarão presentes em meio às análises, executadas segundo interesses específicos, conforme as prioridades estabelecidas em cada momento da pesquisa, aqui apresentadas em seus devidos capítulos. Neste momento, a preocupação foi apresentá-los enquanto vínculos que aproximam os objetos de interesse, autores, obras e sobretudo temática e abordagens executadas no mestrado e no doutorado.

De modo geral, este trabalho encontra-se dividido em quatro capítulos, além desta introdução e uma apresentação das fontes e da metodologia empregada. Os três últimos capítulos estão voltados às análises de fonte já realizadas, de leitura mais verticalizadas, preocupada em compreender a articulação interna dos conceitos tratados pelo autor, a partir de temas a que esta pesquisa pretendeu submeter os textos selecionados. As necessárias relações entre tais resultados analíticos e a farta bibliografia já existente a respeito da obra de Silva Lisboa estão apesentadas ao longo do trabalho, respondendo ao interesse temático. De antemão, as análises de fonte corresponderam ao interesse central do trabalho, daí a prioridade em relação às aproximações ou distanciamentos junto a outras 
análises já executadas sobre a obra do mesmo autor, que hoje compõem farto material historiográfico.

\section{José da Silva Lisboa: aspectos biográficos}

José da Silva Lisboa (1756 - 1835), Visconde de Cairu, como chamado a partir da mercê lhe atribuída em 1826 pelo imperador D. Pedro I, é um personagem cujo significado e importância histórica tem sido debatido pela historiografia de modo recorrente $^{3}$. Originário da cidade de Salvador, Silva Lisboa atravessou o Atlântico para frequentar a Universidade de Coimbra entre 1774 e 1779, chegando a ser nomeado professor substituto de grego e hebraico no Colégio das Artes de Coimbra, no ano de 1778. De volta à Bahia, exerceu o magistério ao lecionar filosofia por dezenove anos, retornando a Portugal em 1797 para publicar obras sobre direito mercantil e economia política. No ano seguinte, estava novamente na colônia, agora deputado e secretário da Mesa de Inspeção da Bahia, de onde partiria sob ordens de acompanhar o príncipe regente ao Rio de Janeiro. Ali atuaria na administração do império e sobretudo na organização de um código de comércio, já sob a condição de deputado da Real Junta de Comércio, Agricultura, Fábricas e Navegação do Estado do Brasil.

A formação intelectual mais rebuscada de Silva Lisboa esteve diretamente ligada à sua passagem pela Universidade de Coimbra, onde ingressou aos dezoito anos de idade ao deixar de lado o propósito de seguir a carreira eclesiástica, conforme outrora lhe havia projetado seu pai, segundo alguns biógrafos. Dificuldades de ordem econômica levaram o jovem baiano, supostamente com menor apoio do pai, a exercer o magistério como meio de assegurar os próprios estudos (cf. CABRAL, 1881, p. 57). Os interesses mais direcionados aos estudos jurídico e filosófico, não impediu que Silva Lisboa se voltasse também às chamadas humanidades clássicas, tendo estudado sobretudo o latim, mas também o grego, formação que o levou a lecionar este último idioma na própria Universidade de Coimbra aos vinte e dois anos de idade.

\footnotetext{
${ }^{3}$ As linhas gerais desse debate podem ser observadas na extensa historiografia voltada à vida e obra de Silva Lisboa. Dentre tal material, podemos citar aquele escrito pelo Professor Antonio Penalves Rocha, pesquisador da obra de Cairu, autor do texto introdutório a uma coletânea que reúne alguns dos mais importantes textos de Silva Lisboa (cf. ROCHA, 2001). Ainda do mesmo pesquisador, é possível identificar um extenso balanço historiográfico a respeito da obra de Silva Lisboa sob título $A$ economia política na sociedade escravista (cf. ROCHA, 1996).
} 
Um ano mais tarde, formava-se em Direito e Filosofia. Posto de lado o intento de ingressar na magistratura ainda em Portugal, Silva Lisboa deixou a capital do reino para retornar a Salvador. Já no Brasil, lecionou grego, fora nomeado professor de Filosofia Racional e Moral pela Real Mesa Sensória, além de praticar a advocacia, tida por ele como algo menor e responsável por um dado relativo afastamento em relação à filosofia ${ }^{4}$. Até que Silva Lisboa retornasse a Portugal, em 1797, seus biógrafos pouco ou nada afirmam a respeito de sua carreira. As esparsas notícias e a ausência de publicações contrapõem-se à efervescência da história política e social do mesmo período, em ambos os lados do Atlântico, a se levar em conta, por exemplo, a Revolução Francesa e a Conjuração Mineira. Em 1797 Silva Lisboa volta a Portugal para a publicação de Direito Mercantil, o que se dá no ano seguinte e que viria a ser tomada como uma obra de direito comercial, responsável pelo início de sua promoção enquanto escritor. No ano seguinte estaria novamente no Brasil, então de modo definitivo.

Na Bahia, no mesmo ano de 1798, Silva Lisboa passa a exercer cargos ligados ao serviço público, sendo o de Deputado e Secretário da Mesa de Inspeção o primeiro a ser destacado $^{5}$. Durante dez anos exerceu o cargo que respondia pela fiscalização e superintendência da vida econômica ligada àquela importante região da colônia, senão do próprio império. Em meio às atividades como funcionário do império português, Silva Lisboa daria sequências às suas leituras e produção escrita. Princípios de Economia Política seria então publicado em 1804, com destaque para a influente presença, bem como seus respectivos laços teóricos junto a temáticas hoje tratadas pela sociologia, antropologia, moral, geografia e história, ainda que submetida à análise crítica, das ideias centrais da obra do professor escocês, Adam Smith. No contexto dessa aproximação ao que viria a ser tomado como o liberalismo, Silva Lisboa deslocou-se ao Rio Janeiro em

\footnotetext{
${ }^{4}$ Em carta endereçada ao então diretor do Jardim Botânico de Lisboa, Domingos Vandelli, Silva Lisboa lamenta os esforços por ele direcionados às questões menores ligadas à advocacia: "Eu tenho já mais de uma vez representado a $\mathrm{V}$. Sa a situação oprimida a que me reduziu, nestas terras, a dureza da minha sorte. Obrigado a ganhar a minha subsistência de mendiga advocacia, vida pouco análoga à constituição do meu gênio, era preciso que desamparasse inteiramente os estudos filosóficos, para me ir perder nos profundos abismos das minúcias e formalidades das intrigas forenses..." (cf. LIMA, 1956, p. 19).

${ }^{5}$ A Mesa de Inspeção e Comércio da Bahia era uma instituição muito ligada aos interesses dos grandes escravistas baianos. Também instituídas em Recife, São Luís do Maranhão e Rio de Janeiro, foram criadas pelo Marquês de Pombal, em 1751, com o intuito de organizar a política tarifária sobre o fumo e o açúcar (cf. SANSON; SPAIZMANN, 2006, p. 260).
} 
1808, de um modo geral acompanhando a chegada de toda uma comitiva e um corpo administrativo trazido por D. João VI.

Nomeado desta vez Deputado da Junta do Comércio, Agricultura, Fábricas e Navegação do Estado do Brasil, Silva Lisboa inaugura sua atuação do Rio de Janeiro de modo destacado, sempre dotado de um propósito conciliador, desde o início antirrevolucionário, posteriormente contra a separação do Brasil em relação a Portugal, mais adiante, convicto monarquista. Tais facetas de sua postura política, sempre expressa em seus escritos de relativa clareza, permitiu que ainda em seus próprios dias fossem projetados sobre si ares de um conservadorismo ou mesmo de um reacionarismo; ares que a posteridade muitas vezes reproduziria a partir de investigações e análises sem a devida profundidade.

Também foi em atribulado contexto de ordem geral, aproximadamente entre 1808 e 1823, que Silva Lisboa passa a escrever em gazetas e periódicos em tom mais acalorado, sempre em franco debate junto a seus adversários políticos, cada vez mais numerosos. Viveu muito próximo do poder, a exemplo do Conselho de Ministros; manteve amizade pessoal com membros da aristocracia local, a exemplo do Conde de Linhares e do Conde da Barca. Tal período de tal agitação do contexto político também foi aquele em que Silva Lisboa produziu Estudos do Bem Comum e economia política ou ciência das leis naturais e civis de animar e dirigir a geral indústria e promover a riqueza nacional e a prosperidade de Estado, publicado pela Imprensa Régia entre 1819 e 1820 . Obra composta por centenas de páginas, voltada à economia política, mas preocupada com as devidas relações junto à moral e sociedade. Mais adiante, Constituição Moral e Deveres do Cidadão com Exposição da Moral Pública conforme o Espírito da Constituição do Império seria publicada pela Typographia Nacional, entre 1824 e 1825.

Tal introdução aos aspectos biográficos de Silva Lisboa caberia ainda registrar sua atuação em cargos de importância, como o de Censor Régio, já a partir de 1808, quando também fora nomeado membro da Junta Diretora da Impressão Régia. Mais tarde Diretor de Estudos. Seja como destacado funcionário público ou por sua atuação de cunho político, panfletário e sobretudo intelectual, pois autor de vasta e variada obra, tal participação de Silva Lisboa rendeu-lhe, para bem e para mal, igualmente vasta e perene atenção. Os comentários abaixo, redigidos por Alceu do Amoroso Lima, encontram-se na introdução de Princípios de Economia Política, publicada em 1956, ano do bicentenário 
do nascimento de Silva Lisboa. Mais uma vez, nota-se em tom exagerado a apropriação de uma obra a partir de interesses do momento da citada publicação, em detrimento de análises que poderiam ou não sustentar os pareceres.

Podemos dizer que o Brasil não deve apenas a Cairu a influência decisiva para a sua independência econômica, de 1808, que precede de catorze anos a sua independência política. Deve-lhe também em grande parte a sua unidade cultural e política... (LIMA, 1956, p. 32).

Mergulhado no processo histórico de tentativa de reestruturação do império português, Silva Lisboa continuou a difundir concepções que também eram fruto de seu trânsito pelos círculos letrados da Europa, experiência que lhe rendeu estreitas aproximações junto às ideias modernas, marcando toda a sua obra de modo muito significativo. O exemplo mais citado dessas influências, talvez por ser a mais explícita, é a presença das concepções de Adam Smith em seus escritos. Entretanto, cabe perguntar por outros aspectos do pensamento ilustrado ali presentes, sendo um deles a cosmologia científica proveniente da filosofia natural, afinal, a considerar a obra de Silva Lisboa, notase que tal problemática pode ser explorada a partir das fontes de pesquisa selecionadas.

\section{A cosmologia de Silva Lisboa e a filosofia natural dos modernos}

Aluno na Universidade de Coimbra em pleno contexto da reforma dos estudos universitários promovida pelo Marquês de Pombal, Silva Lisboa esteve inserido em ambiente intelectual no qual o pensamento ilustrado foi debatido em larga medida. Tal pensamento também expressava uma determinada cosmologia, que por sua vez comportava uma variada temática, na qual estava inserido o tema da ciência. Tal afirmação se sustenta porque ao buscar fornecer uma certa matriz de inteligibilidade dos fatos e permitir uma determinada cognição do mundo, a cosmologia expressa por Silva Lisboa apresenta fundamentos que encontrou nas ciências; uma cosmologia que, em alguma medida, compartilhava aspectos retirados da filosofa natural daquele período.

Autor da obra que é de interesse desta pesquisa, Silva Lisboa foi confesso admirador de Adam Smith, em cuja obra obteve elementos científicos constitutivos de sua cosmologia. E tal quadro conceitual pode ser identificado nos escritos de Cairu referentes 
às questões luso-brasileiras ligadas à formação histórica, projetos econômicos e políticos, bem como em análises a respeito da formação e organização da sociedade brasileira. $\mathrm{O}$ trecho abaixo é um indício evidente da presença dessa cosmologia cientificista nos escritos de Silva Lisboa:

O Universo criado é um Sistema, organizado de partes, que estão em harmonia entre si, e com o Grande Todo, e é regido por Leis Imutáveis da Ordem Cosmológica, que a Inteligência Eterna determinou, e que invariavelmente, se executam no Mundo Físico. A constância e imutabilidade dessas Leis é o fundamento de todos os nossos conhecimentos. [...]

Como a astronomia inquire as leis que regem as orbitas dos Astros no Sistema Planetário; e a Zoonomia investiga as Leis da vida dos animais, assim também a Economia Política examina as Leis que o Autor da Natureza estabeleceu no Sistema Social, ou Ordem Civil, para a subsistência, multiplicação, e prosperidade dos homens, desenvolvendo eles as suas qualidades sociais, e faculdades do espírito e corpo (LISBOA, 1819, p.148).

Nota-se acima que o autor, na esteira dos pensadores tipicamente modernos, compartilha uma cosmologia segundo a qual o universo está organizado conforme um sistema que funciona obedecendo a leis imutáveis, segundo uma ordem cosmológica determinada por uma Inteligência Eterna, ou seja, estabelecida por algo que lhe é exterior, o que chama de Autor da Natureza. Analisar os elementos da cultura científica presente na cosmologia compartilhada por Silva Lisboa nos permitirá compreender o modo como concebia, sem hesitar, a possibilidade de conhecer os princípios da economia política pelas mesmas razões que a astronomia e a zoonomia podiam conhecer os astros e a vida dos animais, ou seja, perguntando pelas leis e pela ordem cosmológica executadas de modo invariável no mundo físico, mas que de alguma forma também atuavam nos sistemas sociais.

Como é possível notar, o ideário proveniente da cultura letrada europeia não respeitou os limites impostos pela condição de colônia e esteve presente em terras da América Portuguesa desde longa data. Tal presença despertou o interesse dos historiadores sobre as condições em que a recepção dessas ideias se deu ${ }^{6}$. Em meio ao ideário da cultura

\footnotetext{
${ }^{6}$ Em se tratando do período de abordagem da presente pesquisa, podemos citar o trabalho de Maria Beatriz Nizza da Silva, A cultura luso-brasileira. Da reforma da Universidade à independência do Brasil, no qual esta historiadora analisa a formação intelectual de uma cultura luso-brasileira, bem como sua
} 
letrada, a presente proposta de pesquisa isolará o tema da ciência, mais propriamente o tema da racionalidade científica, explorando questões ligadas à apropriação de teorias e conceitos da filosofia natural, expressos nos estudos realizados por José da Silva Lisboa acerca da formação histórica brasileira, com ênfase nos aspectos econômicos dessa formação.

Nos dias de Silva Lisboa, o universo letrado tinha a filosofia natural enquanto referência maior no que diz respeito ao modo de produzir conhecimento. Tratava-se ainda de uma das faces do pensamento ilustrado, ou ao menos do que aqueles pensadores afirmavam ser o seu procedimento investigativo. As crenças e superstições deveriam ceder lugar às conclusões fundamentadas em um novo procedimento epistemológico, no qual a razão, alimentada pela experiência e pela observação, deveria proporcionar um saber a ser demonstrado e sobretudo compartilhado de modo suficiente. Esse novo proceder analítico residia na filosofia natural, porque ali teoria e método eram os mais convincentes, muitas vezes munidos de sofisticado instrumental matemático, capaz de saciar a afamada sede de razão dos pensadores iluministas. Para o universo letrado do século XVIII, o trabalho que melhor correspondia a tais perspectivas era a obra de Isaac Newton, maior referência daquela ciência iluminista ${ }^{7}$.

Os estudos sobre filosofia natural compõem a parte até então mais notória da obra de Newton; em diálogo com as principais questões das escolas filosóficas do século XVII, tais como o mecanicismo de Descartes e os estudos de Galileu, o pensamento de Newton herdou e concluiu a Revolução Científica. A recepção da obra de Newton, sobretudo os Princípios Matemáticos de Filosofia Natural, ou mesmo a Óptica, gerou entre os círculos letrados da Europa iluminista o fenômeno intelectual denominado newtonianismo, decorrente dos variados modos com que tal obra foi compreendida e principalmente divulgada para além do restrito círculo de especialistas em ciência física e matemática.

respectiva atuação desde a reforma da Universidade de Coimbra até o período da independência do Brasil (cf. SILVA, 1999).

${ }^{7}$ De modo geral, essa perspectiva pode ser encontrada, por exemplo, a partir da obra de Ernest Cassirer, $A$ filosofia do Iluminismo, e que é retomada em obras mais recentes, como a de Jonathan Israel, ambas mencionadas e comentadas mais adiante, passando também por obras cuja temática é diretamente voltada à História da Ciências, a exemplo do trabalho de Paolo Rossi, $O$ nascimento da ciência moderna na Europa, ou ainda abordagens voltadas à História das Ideias, que não exclusivamente científicas, como é o caso da obra de Paolo Casini, Newton e a consciência europeia. 
É farta a bibliografia atual sobre o tema newtonianismo e variado o leque de abordagens. No início dos anos 2000, o historiador Jonathan Israel publicou Radical Enlightenment: Philosophy and the Making of Modernity (1650 - 1750), e Enlightenment Contested Modernity, and the Emancipation of Man (1670 - 1752). Segundo Israel, o newtonianismo presidiu a principal corrente moderada do Iluminismo, compartilhando um modelo explicativo que restabelecia a ordem e a legitimidade do conhecimento numa época de tantas incertezas:

\begin{abstract}
Newtonianismo, então, não foi apenas uma descrição do sistema planetário e das leis da mecânica e da gravidade, mas foi considerado no Iluminismo essencialmente como uma filosofia, demonstrando de forma totalizante aquilo que nós conhecemos, e assim considerado como uma poderosa arma contra os espíritos fortes. O newtonianismo foi entusiasticamente abraçado como um meio de restaurar a ordem e a certeza, destruindo a incredulidade e o materialismo (ISRAEL, 2006, p. 202).
\end{abstract}

Tratava-se de um movimento intelectual que surgiu a partir das apropriações das ideias científicas de Isaac Newton por um público culto não tão especializado, mas disposto a debatê-las e incorporá-las em outros horizontes de investigação, como as ciências do homem, por exemplo. Isso já fora apresentado de modo suficiente na obra de Ernest Cassirer, que Josep Fontana afirma ser um livro abstrato e simplificador ${ }^{8}$, mas que qualquer pesquisa razoável acerca do período o toma como leitura necessária:

Nota-se assim que a nova física proposta por Newton em finais do século XVII tornou-se um novo paradigma teórico e explicativo para todo o conhecimento. Experiência, observação, demonstração matemática, possibilidade de previsão de fenômenos: tudo isso em muito atraiu os iluministas e instruiu suas argumentações. A partir de então o método experimental, apoiado em razões matemáticas, passou por irreversíveis progressos e adquiriu verdadeira autonomia. Ao voltar seus esforços aos estudos da dinâmica e torná-la uma ciência capaz de compreender não somente os fenômenos físicos terrestres, mas também os celestes, Newton deu corpo ao mais autêntico modelo deste novo saber: "As ciências físicas e as ciências humanas passam a imitar a sua ordem racional e as suas leis. Era ela a nova ciência primeira" (CASINI, 1995,

\footnotetext{
${ }^{8} \mathrm{O}$ ponto de partida e uma maior explanação do comentário acima pode ser verificado a partir da nota 1 do capítulo 4 da obra de Fontana (cf. FONTANA, 2004, p. 108).
} 
p. 60). O newtonianismo foi o ponto culminante de uma verdadeira crise de consciência europeia ${ }^{9}$, promovendo uma rearticulação do saber e dos modos de alcançá-lo.

Sendo rapidamente apresentado o newtonianismo enquanto a principal tendência intelectual, que originária da filosofia natural viria influenciar todo $o$ pensamento iluminista, se faz necessário algumas considerações sobre a recepção desse ideário ilustrado pela cultura letrada luso-brasileira; primeiramente de um modo mais geral, para em seguida tratar do que mais interessa ao presente estudo: as questões ligadas à racionalidade científica e sua presença na obra de José da Silva Lisboa.

Há uma considerável bibliografia sobre a presença das Luzes em território brasileiro, a partir da qual é possível identificar alguns eixos interpretativos. Dentre exemplos mais notórios, podemos apontar as análises formuladas por Maria Odila Leite da Silva Dias, Fernando Novais e Kenneth Maxwell ${ }^{10}$. Os três historiadores possuem estudos voltados a compreender a presença das ideias iluministas no Brasil, embora tenham interesses de pesquisa diferenciados. A professora Maria Odila preocupou-se com o problema da circulação de ideias; Novais com a política econômica; Maxwell ateve-se a questões acerca das ideias revolucionárias. Para todos eles, a ilustração assumiu no Brasil um caráter utilitário; aqueles que de alguma forma adotaram tal ideário em terras coloniais tinham em mente encontrar soluções para problemas práticos locais, quase sempre voltados à modernização da colônia. A análise de Maxwell enfatiza também o caráter independentista, o que não faz a análise de Maria Odila, enquanto Novais entende a ilustração brasileira como moderada. Perante tais abordagens, o tema da ciência é visto a partir do problema da aplicação e da finalidade, concluindo que a ciência era tida como mais um dos fatores a promover melhorias de ordem material que deveriam estar voltadas às demandas da produção.

\footnotetext{
${ }^{9}$ A expressão "crise de consciência" faz menção direta à obra do historiador Paul Hazard (cf. HAZARD, 1948).

${ }^{10}$ As observações apontadas tiveram como ponto de partida o trabalho de Fernando Novais, sob título $O$ reformismo ilustrado luso-brasileiro: alguns aspectos, inserido na coletânea Aproximações: Estudos de história e historiografia, mas publicado originalmente na Revista Brasileira de História, n. 7, pp. 105108, 1984 (cf. NOVAIS, s/d). O mencionado trabalho de Maria Odila é Aspectos da Ilustração no Brasil, artigo que data de 1968, cuja importância ainda ecoa no debate acadêmico. A mesma tese é retomada e ampliada a partir do artigo A Interiorização da Metrópole, publicado em 1972. Ambos os trabalhos encontram-se somados a outros na publicação de 2005, A Interiorização da Metrópole e outros estudos. Já em relação a Kenneth Maxwell, trata-se do trabalho intitulado A Devassa da Devassa, publicado em 1977.
} 
Quando atrelado aos estudos que abordaram as ideias ilustradas no Brasil, o tema da ciência quase sempre se mantem ofuscado e as atenções se voltam à economia e à política, temas clássicos nos estudos sobre o período. Muitas vezes é difícil escapar às interpretações mais arraigadas a respeito da formação do próprio pensamento político, como se pode notar em um texto um tanto recente, no qual o sociólogo Francisco Weffort reproduz a controvertida interpretação que vê a ilustração portuguesa, bem como seus desdobramentos na colônia, apenas pela ótica do considerável atraso em relação à França, Inglaterra, Holanda, colocando-a junto à Espanha, Áustria, Rússia e Prússia (cf. WEFFORT, 2006). O tema da ciência surge apenas no sexto capítulo, quando o autor se põe a tratar o século XVIII. Sob o título Verney e Pombal: Ilustração e Despotismo, Weffort esbarra na temática da ciência moderna ao comentar o empirismo expresso no Verdadeiro Método de Estudar ${ }^{11}$, identificando ali uma concepção filosófica consagrada pela reforma educacional iniciada por Pombal e que foi responsável por abrir as portas da Universidade de Coimbra ao ensino da filosofia natural newtoniana. Deste modo, conclui que Portugal vivenciou um Iluminismo ajustado ao absolutismo e mesmo ao catolicismo, tendo como objetivo limitar o poder da Igreja, subordinando-a ao Estado; o intento era o de propagar o espírito laico, promover uma nova forma de atividade científica, secularizar a educação, desenvolver o comércio e a indústria.

O leque de trabalhos cujo foco esteve lançado sobre questões políticas é vasto, embora as abordagens possam variar. As de cunho estrutural, como a de Fernando Novais, estiveram voltadas a compreender as partes a partir do todo; as conjunturas são explicadas a partir do momento em que se pode compreender as transformações estruturais, ligadas sobretudo à economia. A independência, por exemplo, se deu em meio a uma crise de crescimento, onde os padrões de relação entre a metrópole e a colônia estavam se alterando. Assim, para compreender o movimento de ideias do século XVIII, o que

${ }^{11}$ De autoria de Luís António Verney, opositor exaltado da ação pedagógica da Cia. de Jesus, o Verdadeiro Método de Estudar foi publicado em 1746, cuja repercussão e polêmica desencadeada assegurou a Verney um lugar entre os principais nomes do iluminismo ibérico. Trata-se de uma obra de fôlego, publicada em cinco volumes, que aborda temas diversos, passando pela ética, física, lógica, medicina, teologia, moral, jurisprudência, entre outros. Escrita em forma de cartas dirigidas formalmente ao Reverendo Padre da Universidade de Coimbra, utiliza de uma linguagem simples, de compreensão acessível a um público não tão erudito, ao qual parece de fato se dirigir em tom divulgador. Na carta de mais de uma centena páginas dirigida exclusivamente aos estudos da física, Verney divulga o método newtoniano e recomenda sua adoção nos sistemas de ensino português, saindo em defesa dos modernos e em franca oposição à escolástica. 
chamou de "postura mental", é necessário voltar as atenções ao problema do "atraso" e da "decadência" portuguesa (NOVAIS, s/d, p. 172). Contudo, e sem necessariamente instaurar qualquer incompatibilidade com os estudos estruturais e seus diagnósticos, há outras abordagens que podem enriquecer o saber e mesmo ampliar o debate acerca da formação de uma cultura intelectual brasileira. No caso de Silva Lisboa, em particular, é possível mostrar como o próprio fluxo das ideias pode estar voltado a temas estruturais, tais como política, moral e economia, e a partir deles propor alguma reflexão preocupada com questões de variada ordem conceitual, no caso presente, as respectivas relações com saberes provenientes da filosofia natural.

Por demanda da pesquisa de mestrado, foi possível uma aproximação introdutória a obras que trataram a recepção das ideias ilustradas no Brasil. Dentre elas, podemos citar o trabalho de Eduardo Frieiro, O diabo na livraria do Cônego, publicado em 1945, e Igreja, Iluminismo e Escolas Coloniais Mineiras, publicado por José Ferreira Carrato em $1968^{12}$. Ambas tratam sobre a circulação de obras e ideias nos locais frequentados por uma certa elite letrada colonial, tais como o Seminário de Mariana, a Biblioteca da Casa do Recife, o Mosteiro Beneditino do Rio de Janeiro, onde historiadores já haviam identificado a presença da obra de Luís António Verney, por exemplo ${ }^{13}$. Após as famigeradas reformas no sistema de ensino português, promovidas sob o governo de Marquês de Pombal, as ideias ilustradas passam a atravessar o Atlântico com maior frequência, desembarcando nos livros e, sobretudo, no ideário de professores destinados à difícil tentativa de laicizar o ensino nas escolas da colônia. A figura de José Joaquim de Azeredo Coutinho (1742 - 1821) é um destacado exemplo nesse contexto. Bispo responsável pela fundação do Seminário de Olinda e apontado por muitos como a mais

${ }^{12} \mathrm{O}$ quarto capítulo da mencionada obra de Carrato trata das ideias ilustradas em Minas Gerais, em especial o caso das reformas pombalinas, quando enfatiza a atuação dos oratorianos em oposição à preponderância dos jesuítas nos sistemas de ensino, fosse no reino ou em terras coloniais. Delimitando os subtemas, Carrato aborda a reforma no que diz respeito aos conteúdos curriculares, a prática científica na colônia e os círculos intelectuais na região das Minas Gerais (cf. CARRATO, 1968, p 138 - 208). Cabe observar que o autor enfatiza especialmente o que naquelas reuniões havia de discussão política, para destacar as possíveis relações com a Inconfidência Mineira. Um outro olhar poderia procurar também pela cultura científica do Iluminismo, que mais uma vez fica ali sugerida, mas não analisada a contento.

13 Acerca da recepção das ideias de Verney no Brasil, podemos encontrar informações a partir de um dos últimos trabalhos do historiador António Alberto Banha de Andrade, Verney e a projeção de sua obra, publicado em 1980, portanto já tributário das pesquisas anteriores. Embora muitas vezes de modo indireto e nem sempre notável, Verney exerceu influência sobre o público letrado brasileiro, seja nas escolas oficiais ou mesmo naquelas de orientação religiosa, onde identificou-se sobretudo a presença do $D e R e$ Logica e a influência do Verdadeiro Método, de um modo geral (cf. ANDRADE, 1980, p. 84 - 86). 
importante figura do Iluminismo no Brasil, muito influenciado pelo espírito fisiocrático, Azeredo Coutinho esteve preocupado com diversas áreas de estudo e tinha em vista promover melhorias na colônia, em especial as de cunho econômico (ANDRADE, 1977, p. $56-57)$.

Uma vez atento à necessária contextualização, projetar as atenções para os anos finais do século XVIII e início do século XIX permite identificar e trazer para análise a presença dessa racionalidade científica operando nos diagnósticos acerca da formação histórica da nação. Tal realização torna mais rico e promissor o debate a respeito do processo histórico ligado à cultura intelectual luso-brasileira ${ }^{14}$, desta vez a partir de um viés relacionado à história das ciências, de uma cultura científica então nascente e que alimentou a cosmologia de muitos intelectuais. A partir da obra de letrados luso-brasileiros como José da Silva Lisboa, não é difícil notar a recepção e o uso de teorias e métodos elaborados pelo que fora a filosofia natural e viria a ser as ciências naturais. Na citação abaixo se encontra um parecer próximo ao intento deste projeto; nele o pesquisador Pedro Meira Monteio, em estudo publicado em 2004, identifica na obra de Silva Lisboa o problema ao qual esta pesquisa pretende lançar sua atenção:

... a substituição progressiva da ordem Providencial pela simples ordem econômica, não menos providencial que aquela, é verdade, embora a razão ordenadora divina se deixe substituir pela razão ordenadora da natureza, a qual terá o filósofo por exegeta. É ainda o logos em todo o caso, que interessa ao moralista-economista (MONTEIRO, 2004, p. 32).

Muitos intelectuais do período a ser analisado submeteram a formação histórica, bem como suas pretensões acerca da nação, a uma visão de mundo também influenciada por critérios da ciência, a uma cosmologia que tinha a ciência de seus dias como referência e mesmo inspiração para suas teorias e conceitos. A filosofia natural era de grande importância para a compreensão do logos mencionado na citação acima. Por isso o intento de investigar a cultura científica inserida nessa cosmologia, a importância que exerceu nas interpretações e projetos que Silva Lisboa teceu a respeito do Brasil. Interessa, aqui, compreender essa dada racionalidade científica, identificar seus limites,

\footnotetext{
${ }^{14} \mathrm{O}$ que pode ser observado na já mencionada obra de Maria Betriz Nizza da Silva, A cultura luso-brasileira. Da reforma da Universidade à independência do Brasil, em especial no primeiro capítulo, intitulado Cultura Científica (cf. SILVA, 1999).
} 
perguntar sobre as condições históricas em que foi recebida e empregada no contexto brasileiro, após ser apropriada junto aos círculos intelectuais europeus, já sob irreversível influência iluminista.

Na obra de Silva Lisboa observa-se esse movimento de ideias mencionado de início, segundo o qual concepções extraídas do ambiente da filosofia natural passam a ser utilizadas em análises e discussões nas quais a temática não dizia respeito à natureza de modo específico. Trata-se de um movimento a exemplo do que se pode observar nas atividades de alguns intelectuais iluministas que, ao se apropriarem das ideias de Newton, por exemplo, mencionando-as e dizendo-se newtonianos, esperavam conferir maior precisão e razoabilidade a seus pareceres acerca de outras áreas do saber, ligadas à política, sociologia, economia, história, moral, como também já dito de início. Muitas vezes tomada de modo pretensioso, a ciência moderna assumia a condição de melhor modelo de racionalidade a ser adotado pelo pensamento ilustrado, e isso também é possível notar na obra de Silva Lisboa.

Embora já observada, tal adoção ainda não tem recebido a devida atenção por parte dos estudiosos do período e do tema, mesmo quando se trata de interpretações sobre a cultura letrada luso-brasileira. Antes do aprofundamento da crise do Antigo Regime e mais ainda do fim do chamado pacto colonial, as ideias ilustradas e seu forte apelo a uma racionalidade decorrente da filosofia natural já circulavam entre a elite letrada da América portuguesa, muitas vezes a partir de homens que tinham vivido e estudado nos grandes centros da Europa. Tudo isso já está apontado de modo suficiente por muitos estudos de até então, porém, ao destacarem sobretudo as implicações políticas e econômicas, quase sempre não consideraram a possibilidade de compreender em detalhes os fundamentos de uma determinada racionalidade, a visão de mundo que em alguma medida orientava as análises e a construção dos saberes a respeito do local sobre o qual pensava e escrevia essa elite letrada, como se compunha, o que poderia oferecer, como funcionava a natureza e a sociedade que havia ali se formado.

No caso da obra de Silva Lisboa, muitos autores já apontaram a presença de uma coerência lógica em sintonia com princípios teóricos apreendidos junto aos autores que lia e estudava de modo criterioso, a exemplo dos teóricos ingleses do século XVIII, como David Hume e o sempre lembrado Adam Smith. A necessidade de um olhar menos influenciado pelo juízo crítico a que Sérgio Buarque de Holanda submeteu a obra e a 
pessoa de Silva Lisboa tem sido sugerida por pesquisadores que vão desde Afonso Arinos, em texto de 1946, passando pelas teses de doutorado de Dea Fenelon, defendida em 1973, e Antonio Penalves Rocha, de 1989, por artigo de Fernando Novais e Jobson Arruda, de 1999, e chegando a trabalhos mais recentes, como o de Tereza Cristina Kirschner, publicado em 2009. A presente pesquisa segue sob direção semelhante, desta vez perguntando por questões ligadas à filosofia natural e uma dada racionalidade científica que se faz presente na obra de Silva Lisboa ${ }^{15}$.

O já citado Ernest Cassirer, em obra intitulada Antropologia Filosófica, conclui que após o Iluminismo a cultura europeia passou a conceber o que chama de razão matemática, através da qual estabeleceu o vínculo entre o homem e o universo, permitindo a passagem de um mundo ao outro. É justamente este o centro de interesse desta pesquisa; compreender como operou, qual a importância de um determinado instrumental teórico da ciência que também atuava na visão de mundo de Silva Lisboa, cuja obra até então foi analisada quase sempre a partir de seus problemas econômicos, políticos e morais. O intento é analisar aquilo que, segundo Cassirer, a partir do período da ilustração passa a ser a chave para o que se pretendia tornar a compreensão verdadeira da ordem cósmica e da ordem moral (cf. CASSIRER, 1951, p. 35). Trata-se de analisar esse novo modo de conceber o universo, que para muitos incluiria o próprio sujeito que se dispõe a conhecer, uma cosmologia científica apropriada por intelectuais não cientistas da natureza e aplicada em análises a respeito de uma diversificada temática, cujo interesse em muito extrapolava a natureza física propriamente dita.

O fato do conceito de cosmologia ser mais familiar aos antropólogos pode motivar certa aproximação junto a essa outra área das ciências humanas, por outro lado, na condição de uma pesquisa ligada à História, é necessário esboçar algumas definições iniciais sobre tal conceito. Se para os astrônomos a cosmologia é tida como o ramo de suas atividades de pesquisa voltado ao estudo das estruturas e evolução do universo, quando

${ }^{15} \mathrm{O}$ mencionado texto de Sérgio Buarque foi primeiramente escrito para refutar o tom bajulatório com que Alceu de Amorso Lima havia tratado a obra e a figura de Cairu. Publicado no Correio da Manhã, em 1946, ganhou maior notoriedade quando inserido na segunda edição do clássico Raízes do Brasil, onde Silva Lisboa foi duramente criticado por compartilhar da ideia generalizada acerca da primazia da inteligência sobre o trabalho manual, de que este possui menor dignidade se comparado às atividades do espírito, para dizer ao modo de Sérgio Buarque. As críticas são fundamentadas em problemas que vão da má tradução ao mau uso que fez Cairu de conceitos atribuídos a Adam Smith. Já os demais textos acima citados, conferir: FRANCO, 1947, p. 87; FENELON, 1973; ROCHA, 1989. p. 21; ARRUDA; NOVAIS, 2003, p. 240; KIRSCHNER, 2009, p. 08. 
tomada pelas ciências humanas a cosmologia é tida como cosmovisão, um modo de ver e entender o mundo, incluindo a participação e as relações humanas nele inseridas, numa espécie de arranjo de coisas, com suas possíveis estruturas e sua possível evolução. Tais concepções já se encontram sugeridas pela etimologia do próprio termo kósmos, a partir do qual os gregos faziam menção ao mundo, ao universo enquanto sua ordenação segundo princípios e leis, o que não deixava de ser uma determinada visão de mundo, também dotada de alguma subjetividade.

Quando perguntado pelo uso do conceito cosmologia em estudos contemporâneos ligados às ciências humanas, encontra-se definições como a de Viktor Stoczkowski, introdutória, mas bastante razoável:

Para a antropologia, o ser humano que pensa o faz no quadro de uma visão do mundo, mais ou menos coerente, segundo cada caso, que abrange os seres, os objetos e tudo o que povoa o real, sobre suas propriedades, suas relações, suas origens e seu futuro. Dando a essas visões sobre o mundo o nome de cosmologias, os antropólogos partem da hipótese segundo a qual as representações cosmológicas atravessam toda a cognição e toda a cultura, nos deixando uma matriz geral de inteligibilidade dos fatos empiricamente observáveis, sejam os de ordem prática, de instituições ou de ideias (STOCZKOWSKI, 2008: 17-18).

Sem explorar, por ora, todas as implicações da definição acima, desde o início é importante destacar a afirmação de Stoczkowski de que as cosmologias atuam em todo o processo de cognição, oferecendo uma matriz geral de inteligibilidade dos fatos, pois é justamente essa matriz geral o objeto deste estudo, interessado em ali identificar e analisar aspectos ligados à cultura científica presentes na cognição, no processo de conhecimento que é concebido ou ao menos compartilhado por Silva Lisboa, a respeito das mais variadas condições do local e tempo em que vivia.

Já o francês Decola, autor de estudos contemporâneos em antropologia, oferece uma definição ao conceito de cosmologia que muito vem a calhar a presente proposta. Note que o autor estabelece sugestivas relações entre cosmologia e ciência, concebidas a partir de uma posição intelectual marcada por boa dose do relativismo dos dias atuais:

A cosmologia é a visão do mundo, a maneira pela qual nós pensamos que nosso mundo está organizado. Quando afirmamos que o mundo é 
composto por entidades naturais, seres humanos e objetos artificiais, nós enunciamos os princípios de uma cosmologia particular, a nossa. Outros povos não estabeleceram essas distinções e vêem o mundo segundo outras cosmologias. Nossa cosmologia tornou possível a ciência, mas é preciso compreender que essa cosmologia não foi, ela própria, produto de uma atividade científica. Ela é, antes, uma maneira de distribuir as entidades do mundo que nasceu em uma certa época e que permitiu as ciências se desenvolverem. Essa cosmologia existe e não faço uma crítica às ciências, simplesmente quero evidenciar que nossa cosmologia não é universal (...) Um dos méritos da antropologia é escapar à ideia de que o presente é eterno, de que o mundo é apenas esse teatro em que estamos hoje, com nossa maneira de pensar, com nossas ideias comuns (...) Eu não coloco, então, as ciências em questão, pois isso seria absurdo. O que eu contesto é a ideia de que a cosmologia que tornou essas ciências possíveis é, em si mesma, científica. Não, ela não o é. Ela é histórica, como todas as cosmologias (DECOLA, 2010, p.62).

É extensa a lista de autores luso-brasileiros a expressar aproximações intelectuais junto à ciência dos modernos de modo geral, autores cujas obras permitem perguntar acerca da cultura científica em suas cosmologias. O trabalho proposto aqui se volta à obra de José da Silva Lisboa, luso-brasileiro inserido em plena crise do Antigo Regime, cuja farta historiografia a respeito, além de dar indícios suficientes sobre a viabilidade de submeter seus textos à problemática aqui sugerida, também demonstra tê-la explorado muito pouco. Assim, esta proposta de abordagem parece ser promissora, tendo em vista a importância da obra de Silva Lisboa e mesmo os debates que a partir dela se deram. Tal problemática pretende ampliar o saber sobre o trabalho de Silva Lisboa, que por sua vez pode proporcionar um rico estudo de caso sobre a importância das ideias e conceitos da ciência na cultura intelectual do período, realizando uma aproximação cuja temática, conforme já afirmado, encontra-se ainda muito pouco explorada.

Faz parte do propósito desta pesquisa identificar e analisar tais elementos provenientes da então filosofia natural, provenientes de uma cultura científica, para assim compreender como eles atuam nas interpretações que Silva Lisboa traçou a respeito do Brasil. Tal possibilidade de investigação histórica está anunciada pela historiografia através de pesquisas que, embora tenham submetido a obra de Silva Lisboa a outras temáticas, são suficientes para informar sobre a relação desse luso-brasileiro com um ideário científico que teve sua origem na filosofia natural, mas cuja apropriação não se limitou exclusivamente ao ambiente científico. Como nos informa Antonio Penalves Rocha, as ideias econômicas do Visconde Cairu incorporaram a elite luso-brasileira no pensamento moderno, superando de algum modo a tradição aristotélica-tomista (cf. 
ROCHA, 2001, p. 205). Ao fazer da ciência moderna instrumental para legitimar um discurso, cuja intenção primeira não era o conhecimento científico em si, mas sim temas ligados à política, à economia, à moral e outros, observa-se então um fenômeno intelectual a exemplo do que foi o newtonianismo ${ }^{16}$, que por sinal está expresso na obra de Silva Lisboa, embora ainda não tenha sido analisado com mais cuidado pela historiografia, como é o caso dos títulos tomados para análise por esta pesquisa, publicados nas primeiras décadas do século XIX.

Aprofundar estudos da história intelectual a partir dessa temática permitiria compreender e avaliar, de modo mais aprofundado, a viabilidade e os riscos dessa delimitação que muitas vezes é imposta entre o conhecimento produzido nas ciências naturais e aquele produzido em outras áreas, tais como o relacionado à economia e à política. É relevante perguntar sobre o que permitia a Silva Lisboa tomar concepções oriundas da filosofia natural, tendo como certo que elas continuariam sendo razoáveis quando aplicadas a outras instâncias do conhecimento ${ }^{17}$. Aprofundar os estudos da história intelectual sobre essas questões permitiria perguntar como Silva Lisboa concebia, por exemplo, que as atuais ciências da natureza e a economia eram áreas do saber que poderiam ser desenvolvidas a partir de teorias inseridas em uma mesma cosmologia, pois seus respectivos objetos de interesse de certo modo pertenciam à mesma ordem natural, cujo mecanismo de funcionamento, em alguma medida, poderia ser conhecido pelo homem. Daí a aplicação de teorias e conceitos da filosofia natural às análises econômicas, políticas e outras de ordem diversa.

${ }^{16}$ A obra de Newton era para Silva Lisboa um modelo de explicação, no qual o movimento dos corpos encontrava-se organizado a partir de um sistema, cuja razoabilidade o permitia ser racionalmente compreendido. O principal intento da ciência da economia seria então voltar-se ao que chamava de Systema Social ou Ordem Civil, para também buscar compreendê-la racionalmente. Para isso, foi de fundamental importância a adoção de uma cosmologia científica que possibilitasse o conhecimento razoável em diversas áreas do saber, seja na astronomia ou na zoonomia, seja nos sistemas sociais. Segundo Silva Lisboa, "O universo creado he hum Systema, harmoniado pelo seu omniscio Architector, composto de varios systemas parciaes do mundo physico e moral: a sociedade civil he hum systema: cada Nação he hum systema parcial do total systema da sociedade civil: tudo nelles he ligado por constantes Leis, relações naturaes, de que depende a sua ordem, conservação, ou destruição" (LISBOA, 1819: 68).

${ }^{17}$ Sua postura científica também foi fruto, por exemplo, de sua passagem pela Universidade de Coimbra, onde assistiu aulas de história natural lecionadas por Domenico Vandeli, divulgador dos trabalho de Lineu, portanto, é certo que foi influenciado pelas ideias ilustradas, bem com que as tenha projetado em suas atividades na administração do império português, que então passava por um processo de crescente racionalização (cf. KIRSCHNER, 2009, p. 85 - 102). 
A historiografia sobre Silva Lisboa é farta e parte dela indica a viabilidade de se perguntar sobre as relações históricas entre uma determinada cosmologia científica e a obra de pensamento desse intelectual, voltado a analisar o Brasil justamente no período em que passava a deixar a situação de colônia para tornar-se Estado e nação independente. São muitos os trabalhos que perguntaram sobre os pressupostos que serviram de base para Silva Lisboa pensar acerca da sociedade colonial e do Brasil independente, cujos primeiros passos de formação ele acompanhou tão de perto. A pesquisa de Tereza Cristina Kirschner ${ }^{18}$ é um dos exemplos, e sugere a viabilidade, senão a necessidade, de lançar à obra de Silva Lisboa as indagações aqui sugeridas. Afinal, sob a autoria desse lusobrasileiro encontram-se textos que passam pela economia, filosofia, história, jurisprudência, direito mercantil, política e religião, sem contar as implicações relacionadas ao problema da moral, a que o pesquisador Pedro Meira Monteiro deu farto tratamento, em uma tese de doutorado repleta de implicações historiográficas que merecem ser exploradas.

Como é possível notar, Silva Lisboa foi mais um homem das letras, como assim eram chamados no século XVIII os intelectuais que pensavam sobre diversas áreas do saber, hoje tão bem delimitadas pelas fronteiras da especialização; foi um intelectual que refletiu sobre variada temática, embora tenha ficado mais conhecido por seus escritos sobre economia política (cf. KIRSCHNER, 2009, p. 12). É vasta a possibilidade de questões acerca dos pressupostos intelectuais de Silva Lisboa. Esta pesquisa voltou-se àquelas que possibilitem identificar e analisar em tais pressupostos a atuação de uma

\footnotetext{
${ }^{18}$ A tese de doutorado da historiadora Tereza Cristina Kirschner, intitulada José da Silva Lisboa, Visconde da Cairu: Itinerário de um ilustrado luso-brasileiro, embora não realize análises na direção desta que estamos a sugerir, já aponta a problemática à qual esperamos submeter a obra de Silva Lisboa (cf. KIRSCNER, 2009: 302 - 317). Trata-se de um trabalho, que retoma e amplia o debate com as tradicionais e por vezes polêmicas interpretações já realizadas pela historiografia. Na primeira parte de sua tese, o trabalho de Kirschner esteve voltado à trajetória de Silva Lisboa; a historiadora abordou temas que passam pela formação em Coimbra, a atuação da Mesa da Inspeção da Agricultura e Comércio, bem como na Corte do Rio de Janeiro em pleno contexto do fim da colônia e início do Império brasileiro, resultando numa análise que chega a somar duas centenas e meia de páginas. A segunda parte está voltada a analisar as ideias de Cairu no contexto intelectual da época, iniciando com um balanço historiográfico sobre o Iluminismo, seguido de aproximações e distanciamentos entre as ideias de Silva Lisboa e a de determinados autores do referido contexto. Embora não sejam aprofundadas e somem pouco mais de três dezenas de páginas, surgem nessa segunda parte sugestivas interpretações da leitura que fez Silva Lisboa de alguns autores modernos, dentre os quais destaca-se o nome de David Hume, Edmund Burke, sobretudo o de Adam Smith.
} 
cultura científica a operar em sua cosmologia, perguntando por seus principais aspectos e analisando suas teorias, métodos e conceitos.

Estender as análises a respeito do ideário que foi base de formação para a obra de pensamento de Silva Lisboa, perguntado sobre a influência de uma ciência iluminista responsável por oferecer elementos centrais para a cosmovisão do autor, sem dúvida, ampliará a compreensão a respeito das ideias desse significativo personagem da história intelectual brasileira. A proposta reside em identificar e analisar os conceitos centrais de uma matriz geral de inteligibilidade dos fatos, a se dizer segundo a definição anterior: tomar para análise as ideias científicas atuantes na compreensão, no processo de conhecimento que é desenvolvido por Silva Lisboa acerca do Brasil; por fim, também explorar questões a respeito do lugar da filosofia natural, do discurso da ciência natural, nas obras daqueles finais do século XVIII e inícios do XIX. Ao abordar autores como Silva Lisboa, quais os prejuízos que assumiria uma compreensão de seus textos que não levasse em conta aspectos da formação cultural a que chamamos de ciência, e que está presente na cosmovisão a partir da qual ele se coloca a conhecer? Parece ser determinante a relação entre o que então chamavam de filosofia natural e outras formações culturais, tais como a economia, tema sobre o qual o autor tanto se debruçou. Mesmo antes de se ter levado adiante as leituras e análises, tinha-se como muito razoável que tal proposta de pesquisa mantinha laços com a história das ciências, porque se tratava de uma investigação a respeito das apropriações e usos de uma determinada racionalidade científica, de uma determinada epistemologia, em um determinado período histórico. Tal investigação informa sobre continuidades e rupturas que Silva Lisboa encontrou na racionalidade científica à qual se filiou: a filosofia natural dos modernos, mais propriamente no instrumental epistemológico de seu modelo científico.

O intento é compreender esse tipo de apropriação da cultura científica por um universo intelectual não formado por cientistas naturais, mas por homens que entendiam ser a sociedade, a política, a economia, formações culturais a serem submetidas a uma análise de cunho científico. Questionar sobre as implicações dessa opção pela racionalidade científica nas análises elaboradas por Silva Lisboa, notar a extensão com que pretendia adotá-la, os limites que identificava ou não, o seu uso como ciência e como ideologia, pretensamente adotado ou não. A história das ciências pode ter como legítimo objeto de estudo o que se passa nas instituições científicas ou nos laboratórios, mas 
também é igualmente legítimo explorar como objeto de estudo o entrecruzamento entre história, ciência, epistemologia e a atuação de uma cultura científica nas mais variadas instâncias sociais. Quanto a isso, a análise sugerida aqui parece comportar aspectos que conferem alguma originalidade diante das interpretações a que a obra de Silva Lisboa tem sido submetida até o momento.

De modo recorrente, a historiografia chama a atenção para o fato de que no período em questão, de finais do século XVIII a meados do século XIX, muitos intelectuais estabeleceram estreita relação entre a filosofia natural e os pressupostos que utilizavam em suas mais diversas análises. Entende-se assim que inúmeros pensadores articulavam suas reflexões acerca da política, da economia e da sociedade a partir de aspectos encontrados na filosofia natural. No entanto, tratava-se também de uma visão moral sobre o homem e as sociedades, orientando as mais variadas análises ${ }^{19}$. Boa parte dessa mesma historiografia dá indícios de que é possível elaborar questões problematizadas acerca das relações entre a filosofia natural e os pressupostos adotados nas análises acerca do Brasil $^{20}$, o que possibilita identificar e analisar as condições com

${ }^{19}$ Além da citada obra J. F. Carrato, intitulada Igreja, Iluminismo e Escolas Mineiras Colonias, na qual esse autor identifica em círculos intelectuais da colônia influências do ideário iluminista atuando junto às medidas laicizantes das reformas pombalinas, vale citar novamente o trabalho de Pedro Meira Monteiro, porque este vai ao encontro do que está sendo mencionado, ou seja, a relação entre uma filosofia moral ou mesmo um discurso moral, e as ideias de Silva Lisboa a respeito do contexto brasileiro. O capítulo intitulado Leituras Cruzadas chama a atenção à leitura que fez Silva Lisboa das máximas de Rochefoucauld, diante das quais coloca-se em oposição tendo por base as leituras que havia feito de autores ingleses. Meira Monteiro analisa a francofobia de Silva Lisboa a partir da anglofilia desse mesmo luso-brasileiro, o que não deixa de ser uma possibilidade interpretativa que merece ser aprofundada, visto que é mais tradicional aproximar a elite letrada brasileira da influência intelectual francesa. No referido capítulo, encontra-se destacado e analisado Silva Lisboa leitor de David Hume, filósofo inglês cujas ideias aparece de modo recorrente em Constituição moral e deveres do cidadão, publicada entre $1824 \mathrm{e}$ 1825 (cf. MONTEIRO, 2004, p. 160 - 167).

${ }^{20}$ Podemos destacar dois exemplos, a fim de tomá-los como um contraponto: a pesquisa de Maria Margaret Lopes, O Brasil descobre a pesquisa científica: os museus e as ciências naturais no século XIX; e a pesquisa de Márcia Regina Naxara, Cientificismo e sensibilidade romântica: em busca de um sentido explicativo para o Brasil no século XIX. A primeira autora volta-se a compreender a institucionalização das ciências a partir da criação dos museus, recusando a tese de que não houve produção científica no Brasil até o início do século XX. É com esse propósito que analisa, entre outros casos, a criação da Casa de História Natural, ainda no contexto das reformas de Pombal, ou mesmo as expedições de exploração organizadas por Portugal, que em finais do século XVIII passaram a ser cada vez menos militares, geopolíticas e mais filosóficas - botânicas e mineralógicas (cf. LOPES, 1997, p. 30). Já no segundo trabalho, a respectiva autora tomou para análise as correntes de pensamento citadas no título, concluindo que ao se pensar sobre o Brasil em formação, sobretudo no que dizia respeito à sociedade, a sensibilidade romântica havia exercido grande influência sobre a postura científica: "A ambivalência permanece e acompanha essa história: mais se conhece a natureza, mais ela se torna fonte de reverência e assombro pelos segredos que esconde, por mais que, pelos procedimentos da ciência, venha sendo crescentemente 
que muitos intelectuais do período tomaram a filosofia natural para compor suas respectivas matrizes de inteligibilidade.

Trata-se de voltar-se ao estudo de caso indicado aqui, à obra que será objeto de dos interesses desta análise, buscando compreender como ali operam conceitos admitidos em razoável consenso e em torno dos quais se alimentava a ideia de submeter à razão questões ligadas à natureza e à cultura; relação que expressa o esforço tipicamente iluminista de uniformizar, não somente o conhecimento, mas o próprio modo de produzilo. Trata-se de considerar e explorar uma problemática que também é possível e pertinente aos estudos da História: a análise das relações entre um modelo de conhecimento adquirido junto à filosofia natural e problemas ligados ao contexto histórico no qual atuava o intelectual portador dessa cultura letrada. Trata-se de perguntar sobretudo pelas especificidades com que tais ideias foram apropriadas e aplicadas, segundo condições históricas e projetos diretamente ligados ao contexto em que atuava o autor em questão, José da Silva Lisboa.

\section{As fontes históricas: justificativas e métodos de abordagem.}

Acerca da escolha dos textos a serem tomados como fontes desta pesquisa, cujo interesse está dirigido à cosmovisão de José da Silva Lisboa e aos elementos de uma dada filosofia natural corrente no contexto intelectual de sua época, é necessário expor justificativas. As obras de Silva Lisboa aqui tomadas para análise correspondem justamente àquelas em que o recorte temático apontado pela pesquisa pode ser melhor identificado e explorado. Trata-se assim de tomar como fontes históricas as obras de Silva Lisboa a partir das quais a investigação acerca da relação entre as ideias ilustradas e a obra de pensamento deste autor parece ser mais promissora. De modo geral as ideias ilustradas;

desvendada. A construção alegórica do mundo, que opera com os limites da natureza e do artifício, representação mental, leitura da natureza e da ação dos homens, formulada em grande parte com o auxílio da imaginação" (cf. NAXARA, 2004, p. 78; idem, p. 131). Essa ênfase em uma certa perda de objetividade, sob influência da postura romântica no discurso da ciência, poderia ser avaliada ao se analisar o legado de expedições que buscaram conhecer o Brasil de modo científico, tais como as expedições patrocinadas pelo Estado, por exemplo. Assim, ter-se-ia uma tentativa de inversão, ou seja, de compreender o processo histórico de submeter a imaginação, o encanto ou o assombro a respeito da natureza, a uma investigação de pretensões científicas e que prezou por uma determinada objetividade, analisando seus sucessos e seus fracassos, afinal, encanto, assombro, imaginação, sabemos, sempre estiveram presentes no processo de construção do conhecimento, e isso não impediu que muitas vezes ele se tornasse um saber razoável. 
de modo mais específico as que fazem referência à filosofia natural. As obras e textos de Silva Lisboa aqui tomados para análise foram aqueles em que a temática que orienta a pesquisa se faz presente de modo mais claro, permitindo considerável aprofundamento das análises. A seleção de fontes pretende estar justificada pela possibilidade de formular e responder questões a respeito de elementos da filosofia natural e do Iluminismo em geral ali presentes.

Portanto, o principal critério para justificar a seleção de fontes históricas foi o de selecionar um material que comportasse análises de aprofundamento mais teórico, nos quais é possível notar que a preocupação com a lógica parece ter precedido a retórica. Trata-se de um conjunto de textos cujo resultado de sua produção não esteve voltado, de modo mais imediato, a compor um discurso de ordem mais panfletária ou parlamentar, estes de preocupação voltada a demandas pontuais e específicas ao momento mais próximo em que foram escritos, talvez com endereço mais preciso, orientados a debates de cunho específico, sobretudo o político.

Sendo assim, as fontes aqui selecionadas para abordagem expressam com maior ênfase a preocupação de Silva Lisboa em expor, analisar, explicar e muitas vezes propor soluções a um dado problema, e que para realizar essa tarefa fez larga utilização de justificativas mais conceituais, de um modo mais prolongado e pormenorizado. Tais características justificam a escolha desses textos como fonte para conhecimento e compreensão da visão de mundo do autor. A levar em conta a verticalidade com que as análises estão ali apresentadas, passando pelo amplo debate com autores que lhe serviram de referência, ou até mesmo pelo próprio volume em que se constituíram, é possível destacar dentre a obra de Silva Lisboa os livros Princípios de Economia Política (1804), Estudos do bem comum (1819-1820) e Constituição moral e deveres do cidadão (1824-1825). Tais obras foram tomadas para o compor o principal conjunto de fontes desta pesquisa, sendo Estudos do Bem Comum aquela a que esta pesquisa largamente submeteu à análise, o contrário ocorrendo com Constituição Moral ${ }^{21}$.

\footnotetext{
${ }^{21}$ As obras selecionadas possuem títulos mais completos, cuja menção é necessária inclusive para indicar as respectivas temáticas de modo mais claro e direto. São eles: Princípios de Economia Política para servir de introdução à teoria Econômica do autor dos Princípios de Direito Mercantil; Estudos do bem comum e economia política ou ciência das leis naturais e civis de animar e dirigir a geral indústria e promover a riqueza nacional e prosperidade do Estado; Constituição moral e deveres do cidadão com exposição da moral conforme o espírito da constituição do império. A primeira fora publicada em Lisboa, pela Impressão
} 
A leitura e submissão de tais obras a abordagens mais pormenorizadas torna possível ao leitor notar que, através delas em especial, a intenção de Silva Lisboa foi a de explicitar e submeter suas concepções à atenção e análise de um determinado público, talvez mais erudito, certamente mais restrito, por ventura disposto a um debate mais conceitual do que parlamentar, este último aqui pensado no que diz respeito a embates e esforços voltados a questões conjunturais de seu tempo. Ainda que especulativo, tal critério para escolha das fontes comporta razoabilidade, além de não excluir a possibilidade de que muitas vezes havia uma diversidade de atitudes leitoras naquele mesmo contexto histórico.

O historiador português, Armando de Castro, em obra intitulada $O$ pensamento económico no Portugal moderno, apresenta e tece análises introdutórias sobre o referido tema, dispondo de modo praticamente cronológico os principais pensadores de cultura lusobrasileira que trataram da economia. Ao tratar a obra de Silva Lisboa, selecionou aquelas que classificara como estudos econômicos não restritos a casos em específico, mas sim de ordem abstrata e teórica, com preocupações de ordem geral. Segundo Castro, Princípios de Economia Política, bem como Estudos do Bem Comum, por exemplo, são obras de economia teórica, "suficientemente representativas do pensamento doutrinal e da evolução que sofreu ao longo do tempo" o pensamento de Silva Lisboa (cf. CASTRO, 1980, p. 71).

Ao redigir os textos aqui tomados como fonte para análise histórica, é razoável considerar a hipótese de que Silva Lisboa levou em conta estarem elas dirigidas a um determinado público leitor. As longas citações, o recorrente apelo às chamadas autoridades nos respectivos assuntos por ele tratados, além de todo um estilo e linguagem certamente mais eruditos, acabava dirigindo esse material a um público ainda mais restrito do que os leitores de panfletos e gazetas, o que já exigia a condição de alfabetizado, consideravelmente seletiva entre a população da época ${ }^{22}$. Mesmo a própria retórica, embora estivesse ali cedendo importância à lógica, se mostra sendo utilizada à altura do público alvo de tais textos mais eruditos. Isso se faz notar, por exemplo, a partir das prolongadas apresentações das teorias e autores então correntes no universo letrado europeu. Ainda que longe de deixar a pretensão de construir uma argumentação lógica, longas menções e mesmo citações a

Régia, em 1804; já a segunda viria ser publicada no Rio de Janeiro, pela Impressão Régia, em 1819-1820; a terceira, também no Rio de Janeiro, foi publicada pela Typographia Nacional, em 1824-1825.

${ }^{22} \mathrm{O}$ que de algum modo corrobora o comentário de Albano Pinto, médico, professor de agricultura, político e estudioso de diversificadas áreas do conhecimento, inclusive da economia, ao afirmar que pensadores como Rodrigues de Brito (1753-1831) e Silva Lisboa não eram autores didáticos (cf. CASTRO, 1980, p. 88). 
partir de antigos e modernos, também deveriam operar como instrumental retórico de convencimento junto a tal público leitor, quiçá para além do próprio contexto social e político de temática ou produção do texto ${ }^{23}$.

Com isso, pretende-se afirmar que Silva Lisboa poderia ter sua obra submetida a leituras diversas, por vezes a partir do mesmo leitor. No entanto, quanto às obras a que se refere esta pesquisa, é mais razoável admitir que o respectivo autor estivesse preocupado em apresentar concepções e análises a um público leitor igualmente disposto a uma compreensão mais pormenorizada e conceitual de seu ideário.

Não foi o caso da situação na qual aquele que ainda viria a ser um dos Regentes, Araújo Lima, em Assembleia Constituinte realizada em 1823, data inserida entre as publicações aqui tomadas como fontes, se coloca em oposição a Silva Lisboa: “... o honrado membro apresenta uma massa tal de conhecimentos, que facilmente esmagará aqueles que, como eu, se lhe oferecerem em campo" 24 . Em menção direta a Silva Lisboa, Araújo Lima reconhece, talvez sem ironia, o cabedal intelectual de seu interlocutor parlamentar, mas segue em sua oposição. Ainda que as críticas de tal oposição reconhecessem a sólida formação de Silva Lisboa, o contexto da Assembleia Constituinte parecia não favorecer a disposição prévia de seus interlocutores a tratar conceitos já desenvolvidos em obras de maior fôlego; o embate parlamentar parecia bem menos propício à razoabilidade e sobretudo ao aprofundamento de discussões conceituais.

Em tom mais elevado, uma característica dos periódicos e folhetos brasileiros de um tempo político efervescente, ainda se faz possível notar, em meio às críticas e mesmo às ofensas, o reconhecimento diante da erudição de Silva Lisboa. De modo recorrente, seus opositores fazem menção a seu vasto saber, por vezes servindo como ponte para ironias e insultos. Abaixo, em menção ao senador Silva Lisboa, dois momentos distintos nos quais as

\footnotetext{
${ }^{23}$ Em artigo sob título História Intelectual no Brasil: a retórica como chave de leitura, José Murilo de Carvalho expõe e comenta as mais importantes metodologias de abordagem empregadas pela História Intelectual, menciona a pouca problematização encontrada nos estudos brasileiros realizados por essa área e sugere aproximação entre crítica literária e história. Destaca e justifica a importância de considerar o problema da retórica nos estudos sobre autores do universo letrado luso-brasileiro e, embora esta pesquisa não tenha dado ênfase a retórica, mas sim uma dada e já apresentada abordagem sobre as fontes, foi importante considerar alguns apontamentos lançados no artigo em questão. Um deles foi a distinção entre o argumentum ad personam, voltado à desqualificação do interlocutor, e o argumentum ad hominem, não voltado à pessoa do interlocutor, mas sim a elementos de sua argumentação, talvez mais empregado em discussões filosóficas voltadas ao que a autor classifica de auditório universal (cf. CARVALHO, s/d, p. 141).

${ }^{24}$ Anais da Assembleia Constituinte de 1823. Sessão de 28/08/1823.
} 
críticas, por mais enfáticas e ferrenhas, ou mesmo irônicas, deixam escapar esse reconhecimento.

No primeiro deles, o interlocutor, que a historiografia afirma tratar-se de João Soares Lisboa, sob pseudônimo de Constitucional Regenerado, se coloca diante das propostas defendidas por Silva Lisboa ${ }^{25}$.

Este homem, que tem adquirido o nome de sábio, deseja que a sua opinião dite a 'ordem do dia' e porque assim não aconteceu, ressentiu-se e lançouse na arena para combater o passo mais nobre e mais heroico dado pelo ilustre povo desta cidade ... O ilustre reclamador tem mais de sessenta anos, a sua cabeça é uma biblioteca, porém biblioteca em desarranjo. ${ }^{26}$

Já no contexto dos debates pós abdicação, a fala do senador Alencar:

Eu aprecio muito as luzes do nobre senador que acaba de falar ... Mas também vejo-me obrigado a confessar que o nobre senador está tão aferrado a ideias antiquárias e tão inaplicáveis ao tempo presente, que, de certo, me persuado não poder falar nas coisas de que hoje tratamos. Sua literatura, posto que vasta, quando muito poderia ser própria para o século passado até 1789 , para agora, de certo, não é muito própria. ${ }^{27}$

Ainda que Silva Lisboa tenha dedicado significativos esforços a publicar textos em panfletos e periódicos, muitas vezes criados para exclusiva propagação de suas ideias, esta pesquisa priorizou tomar para análise aquelas tidas como obras de fôlego. Sabe-se que a ideia central, os conceitos e análises propostas em Estudos do Bem Comum, por exemplo, encontram-se apresentadas de modo muito mais sucinto em publicações como Sabatina Familiar de amigos do Bem-Comum (1821 - 1822), cujo tom é de divulgação e a preocupação de abranger um público maior em tempo menor se dá de modo explícito, o que se faz possível notar até mesmo pela escrita e formato da publicação, na qual tece apresentações históricas das Academias de Ciência, com objetivo de defender a criação de

\footnotetext{
${ }^{25}$ Segundo Hélio Vianna, o periódico Reclamação (1822), que soma 14 números, publicados a partir de 9 de janeiro, o chamado Dia do Fico, foi o mais polêmico e o que mais gerou debate entre as propostas de Silva Lisboa e outras publicações, ocasionado variadas oportunidades de respostas (cf. VIANNA, Rio de Janeiro, 1945).

${ }^{26}$ Correio do Rio de Janeiro, n. 39, 23/05/1822.

${ }^{27}$ Anais do Senado Federal, 23/05/1832, v. I, p. 114.
} 
uma universidade no Brasil. No entanto as atenções deste trabalho tomaram como fonte a obra Estudos do Bem Comum, e não sua respectiva apresentação mais compilada, citada acima.

Poderiam ser citadas outras publicações, nas quais Silva Lisboa retomou em tom de divulgação mais simplificada, teses outrora apresentadas em obras cujas análises se deram com maior profundidade. Em textos como Roteiro Brasílico ou Coleção de Princípios e Documentos de Direito Político em Série de Números (1822), mais uma vez concepções e análises de maior fôlego intelectual foram retomadas, parafraseadas, ou mesmo reproduzidas em longas citações, o que confere a tais veículos de maior divulgação também a função de retomar ideias centrais já apresentadas nos livros de maior profundidade analítica e maior extensão, desta em vez em jornais, gazetas, panfletos direcionados a um público mais amplo (cf. VIANNA, 1945, p. 384, 385).

A acompanhar as análises de Hélio Vianna, textos como Império do Equador na Terra de Santa Cruz (1822 - 1823), ou mesmo outros materiais de divulgação mais estendida, como o folheto intitulado Estudos contra o acordo da Junta Eleitoral da Paróquia de São José, de agosto de 1822, nota-se que Silva Lisboa mais uma vez retoma o ideário já exposto em Estudos do Bem Comum, com até mesmo reprodução de trechos desta obra, no caso do segundo exemplo (cf. VIANNA, 1945, p. 392, 416). Sendo assim, esta pesquisa admite a intenção parlamentar de muitos dos escritos de Silva Lisboa, mas em decorrência do interesse primeiro da análise aqui proposta, a compreensão dos conceitos relacionados à filosofia natural e ao ideário ilustrado na obra de pensamento do autor em questão, definiu-se como prioritária as obras já mencionadas, porque tais obras de maior fôlego compõem análises mais verticalizadas, expostas de modo mais extenso, cujas intenções autorais caminham em direção muito semelhante ao conjunto de sua obra, apresentada em atos de fala publicados por meios distintos, para ambiente e postura leitora diversificados.

O conceito de ato de fala é originário de pesquisas voltadas à análise da linguagem ordinária, um esforço para rever uma postura analítica anterior, a qual priorizava a sintaxe; deste modo, recorreu à pragmática e a compreensão da linguagem e seu agir no mundo. Quem fala age, intervém no mundo; isso é um preceito fundamental para os 
pensadores da chamada Escola de Cambridge ${ }^{28}$ e por essa razão eles atribuíram enorme importância à obra de John Austin. Em How to do things with words esse autor apresenta sua teoria dos atos de fala, segundo a qual as palavras não somente geram ações, como são ações em si, interferindo no contexto em que estão inseridas ${ }^{29}$. Finalizando a série de textos fundadores dessa nova proposta historiográfica conhecida como Abordagem Contextualista, é publicado o polêmico artigo de autoria de Quentin Skinner: Meaning and Understanding in the History of Ideas. ${ }^{30}$

O esforço de desse tipo de abordagem reside em compreender o pensamento de um dado autor em seu próprio contexto; sendo assim, ao optar por essa metodologia o historiador deverá reconstruir os discursos do passado, enquanto uma ação engajada nas questões do passado, visando não recorrer ao que é tido como um dos grandes pecados do historiador, o anacronismo. Meaning and Understanding in the History of Ideas é o artigo de Skinner mais conhecido e comentado por fazer parte desse momento de ruptura em relação à tradicional História da Filosofia Política. Naquele texto, dirige-se a autores como Wollin, Leo Strauss, que voltavam-se aos textos do passado submetendo-os à análises que pressupõem temas e questões perenes. Ao contrário desses autores tradicionais, Skinner não acredita que somente o texto seria suficiente para possibilitar a compreensão de um autor. Não aceitando a autossuficiência do texto, defendeu o apelo à reconstituição do contexto linguístico enquanto condição necessária de uma análise razoável.

As obras de Silva Lisboa, selecionadas como fontes desta pesquisa, foram obras assim tomadas por representarem espécies de síntese daquilo que orientava sua visão de

\footnotetext{
${ }^{28}$ A partir de década de 1960 inicia-se uma nova proposta teórico-metodológica voltada para a história intelectual, em especial para a história do pensamento político, que ficaria conhecida como Abordagem Contextualista. Entre os fundadores dessa nova historiografia podemos destacar os nomes de Peter Laslett, J. G. A. Pocok, John Dunn e Quentin Skinner; todos diretamente envolvidos no desenvolvimento do que viria a ser conhecido como a Escola de Cambridge.

${ }^{29}$ A ideia de admitir a ação por meio da fala foi o que na obra de Austin mais interessou aos pensadores da Escola de Cambridge quando desenvolveram a Abordagem Contextualista, cujo marco fundador foi o texto escrito por Peter Laslett, publicado como Introdução dos Dois Tratados sobre o Governo, de John Locke, passando por The History of Political Thought a Methodological Enquire, publicado por J. G. A. Pocock em 1962, entre outros importantes teóricos.

30 Neste trabalho utilizou-se a seguinte tradução do referido artigo de 1969: SKINNER, Q. Significado y comprensión en la historia de las ideas. IN: SKINNER, Q. Lenguaje, Política e historia. Bernal: Universidade Nacional de Quilmes, 2007. Este livro é a tradução de Regarding Method, o primeiro dos três volumes que compõem a obra Visions of Politics, publicada em 2002.
} 
mundo, cuja explicitação em tais ocasiões não esteve restrita a imediatas preocupações, delimitadas por situações em específico, sem com isso deixar de se apresentar em franco diálogo com o contexto linguístico e intelectual em que estiveram inseridas. São obras de cunho mais teórico, cuja ação intencionada é o convencimento a partir do que entendia ser argumentos razoáveis, não necessariamente em detrimento de finalidades práticas mais imediatas. O que aqui se pretende admitir é que em tais obras Silva Lisboa esteve preocupado, de modo prioritário, com a lógica interna de sua argumentação, com a fundamentação de suas concepções, para que assim fossem dotadas de maior capacidade de convencimento junto a um determinado público, para que assim agissem conforme e mediante um dado contexto linguístico e intelectual, sem deixar de lado sua intencionalidade junto ao seu contexto histórico.

São, portanto, atos de fala, mas em tais momentos estiveram voltados a ações junto a certas leituras, mais eruditas e menos parlamentares. No momento em que refletiu e escreveu o que está apresentado nas fontes aqui selecionadas, a se levar em conta o próprio formato, linguagem e extensão de análise e texto, Silva Lisboa parece ter considerado leitores em momentos de maior interesse a abordagens de ordem mais conceitual, dispostos a uma leitura mais vertical das ideias que ali estão sendo propostas. Daí a maior possibilidade de se questionar e analisar a racionalidade interna de suas proposições e mesmo de suas crenças, sem perder o horizonte de que todas elas estiveram inseridas em um dado contexto intelectual e mesmo histórico. São atos de fala direcionados a um ambiente que não aquele voltado, de modo exclusivo, ao debate parlamentar, a discutir demandas de ordem mais pontual, sem no entanto excluir tal intenção em absoluto. Isso se faz possível notar, por exemplo, em trechos como o que encontra-se ainda na introdução de Constituição Moral e Deveres do Cidadão, quando Silva Lisboa se coloca em relação ao advento da Confederação de Equador, ocorrida na atual região Nordeste do Brasil em 1824.

Contra os Revolucionários acachapados no Brasil, ou já escancarados em Pernambuco, que no seu Manifesto traidor propuseram de próximo para os Povos desta Região Solar Bases de uma Constituição sem Religião, só oponho o que bem disse o Heroico Antagonista dos Anarquistas, e Infiéis de todos os Estados - Edmundo Burke -, celebrado Parlamentário de Inglaterra [...] "Conhecemos, e é o nosso timbre confessar, que o homem é, pela sua Constituição, um animal religioso; e que o ateísmo é não só contra a nossa razão, mas também contra os nossos instintos... Se, em algum momento de loucura, rejeitássemos a Religião Cristã, que até o presente tem sido o nosso brasão e conforto, e uma grande fonte da nossa 
Civilização, e de outras Nações, havemos temor justo de que o vazio se encha pela mais incoerente, perniciosa, e vil de todas as superstições" (LISBOA, 1824. Introdução, IX).

Acima, Silva Lisboa explicita sua intenção de ordem parlamentar, inserindo seus posicionamentos em diálogo com o que lhe é imediatamente contextual, a eclosão da Confederação do Equador, no entanto, tal intenção e problemática está sendo mencionada em uma obra de fôlego, como é o caso de Constituição Moral e Deveres do Cidadão, na qual as análises recebem tratamento de maior profundidade, onde um leque muito mais amplo de conceitos pode ser encontrado e, portanto, suscetível de mais ampla análise historiográfica segundo o que aqui está proposto. Daí a escolha desta entre as fontes selecionadas para desenvolver esta pesquisa. Nos parágrafos imediatamente anteriores do trecho acima citado, nota-se essa amplitude no momento em que Silva Lisboa menciona autores que lhes serviam de referência, fazendo de seu texto um convite à tarefa de compreender a racionalidade interna de sua obra em toda a complexidade, o que somente se faz possível se tal compreensão e análise considerar o contexto intelectual em que esteve inserido e agindo em franco debate.

Sendo necessário ampliar a área de terreno antes de fazer o edifício, primeiro exporei os dogmas e erros dos antigos e modernos mais correntes Sistemas de Moral Pública; depois farei a inquirição de suas verdadeiras Bases, e por fim indicarei a análise dos Deveres Morais. Portanto esta obra conterá três partes. Contra os Censores, que, blasonando das luzes do século, estranharem o recorrer eu, como à fonte limpa, à religião Cristã, para confirmar as fundamentais doutrinas da Moral Pública, só digo que até Locke reconheceu no Evangelho a PALAVRA DA VIDA ETERNA, nem sempre firme na crença do Cristianismo; e Newton fez comentário do Apocalipse, extasiando-se com a misteriosa delineação do futuro estado de retribuição dos bons e maus do Mundo invisível (LISBOA, 1824, Introdução, IX).

Nota-se que Silva Lisboa anuncia a estrutura geral com que montou a obra acerca de um sistema de moral pública, instruindo o leitor a respeito de toda uma escola de pensamento junto à qual se aproxima, ainda que ponderando limites e críticas. No que diz respeito à justificativa para a escolha de fontes, fica explícito a variedade do leque de autores a compor suas leituras e referências. Ao chegar ao nome de Isaac Newton, demonstra estar a par da abrangente temática a que se dedicou esse filósofo inglês, que a posteridade viria a tratar como um dos mais reconhecidos cientistas da natureza, físico, matemático, mas ainda 
hoje de modo muito raro enquanto um filósofo interessado em questões ligadas à teologia e escatologia.

A partir de obras como Constituição Moral e Deveres do Cidadão nota-se uma uma disposição em levar a apresentação de conceitos, a elaboração de análises e uma numerosa utilização de citações que possibilitam submeter sua obra a uma investigação a respeito da cosmovisão de Silva Lisboa, na qual elementos da cultura ilustrada e da filosofia natural são afirmados de modo recorrente. Tal justificativa para seleção de fontes dentre a vasta obra desse autor pode ser estendida ao aqui já mencionado e largamente analisado Estudos do Bem Comum, bem como a Princípios de Economia Política, além de outros textos como, por exemplo, Da liberdade do trabalho, chamados à baila conforme possibilitaram complementar e mesmo ampliar as análises, conferindo maior respaldo e razoabilidade às propostas aqui apresentadas, buscando compreensão de uma dada lógica interna na obra de pensamento de Silva Lisboa, como já afirmado.

Em artigo intitulado História intelectual no Brasil: a retórica como chave de leitura, o historiador José Murilo de Carvalho comenta características contribuições e limitações do que classifica como sociologia do conhecimento, destacando o debate entre Roberto Schwarz e Maria Sylvia de Carvalho Franco acerca da chegada do liberalismo no Brasil. Assinala que, embora tais pesquisadores discordem no resultado de suas análises, ambos, segundo seu entendimento, se aproximavam na medida em que compartilham a respeito da radical determinação do contexto social, condicionado pelo modo de produção.

Simplificadamente, Schwarz afirmou que as ideias, sobretudo o liberalismo, no Brasil do século XIX e pelo menos até 1930, estariam fora do lugar. O liberalismo teria surgido na Europa como produto ideológico do capitalismo triunfante. Importado para (por) um país que predominava o modo de produção escravista, ele deixava de ser até mesmo uma ideologia ocultadora da exploração do trabalho, como era na Europa. [...] Franco respondeu que o Brasil, embora escravista, era parte integrante do sistema capitalista mundial. Não haveria nenhuma distinção essencial entre as partes do sistema, todo ele voltado para o lucro. As ideias importadas estariam assim no Brasil perfeitamente em seus lugares CARVALHO, s/d, 125).

Apesar de reconhecer o que chama de avanço nas abordagens historiográficas, José Murilo de Carvalho aponta para a necessidade de reconhecer a pouca problematização da história intelectual no Brasil, cuja incorporação de novas formas de abordagens ocorrem 
de forma fragmentada, demonstrando ser mais promissoras as análises oferecidas pela crítica literária, ao dar maior importância ao debate linguístico e à teoria da recepção. Por sua vez, esta pesquisa pretendeu atender, em alguma medida, essa demanda apontada por José Murilo de Carvalho, pois realizou uma abordagem de certa forma ligada à história intelectual, porém, problematizada pelas questões ligadas à recepção, compreensão e emprego de elementos conceituais identificados no universo da cultura ilustrada e na filosofia natural daquele dado contexto de ideias em que Silva Lisboa esteve inserido e junto ao qual atuou.

Assim, é necessário admitir o peso da retórica nas falas e também nos textos de Silva Lisboa, em grande parte expressão de seu letramento, sobretudo de sua passagem pela Universidade de Coimbra, onde José Murilo de Carvalho destaca a importância dada à retórica naquele espaço de formação marcado pela forte influência dos jesuítas e sua tradição escolástica. No entanto, Silva Lisboa passara por uma Universidade de Coimbra sob imediata $^{31}$ influência das reformas pombalinas, cujo mote central era afastar essa dada influência jesuítica, reformar o conteúdo dos estudos ali desenvolvidos, buscando implantar ali nova postura intelectual, desta vez sob influência do que viria ser tomado como uma revolução científica, mais interessada no empirismo, na análise matemática, na razoabilidade das explicações, na finalidade prática, de preferência econômica de um dado desenvolvimento dos saberes em geral.

Nos textos que aqui serviram de corpo principal das fontes históricas há sim forte apelo retórico, e levar em conta tal presença é condição necessária para as análises aqui desenvolvidas, contudo a preocupação junto ao convencimento do leitor a partir da demonstração e da argumentação razoável também encontra-se muito presente nos mesmos textos, com incontáveis críticas, muitas vezes dirigidas até mesmo às próprias autoridades em que se apoia e as quais tem por referência ao construir uma dada racionalidade interna de sua obra. Silva Lisboa exagera em citações, mas não deixa de criticar esses mesmos autores

\footnotetext{
${ }^{31}$ A expressão imediata influência encontra-se justificada pelo fato de que, conforme estudos inclusive mencionados por José Murilo de Carvalho, muitos estudiosos voltados à reforma da Universidade de Coimbra chamam a atenção para as limitações daquela tentativas de renovação intelectual, que de modo geral não foram tão radicais. Em decorrência do afastamento do Marquês de Pombal, logo após o falecer do rei D. José I, portanto do afastamento de seu maior apoiador, além do destaque mantido às chamadas Letras Humanas, que incluía línguas, retórica e poética, que não cedeu a posição de base de todo o conhecimento para a influência de pensadores como Locke, ou de modo geral o experimentalismo e o utilitarismo, tidos pelos reformadores como o espírito moderno de produção de conhecimento (cf. CARVALHO, TOPOI, p. 133).
} 
quando em suas respectivas obras encontram-se ideias com as quais não se alinha. Assim o faz com Malthus, Locke, Hume, Isaac Newton e outros autores que poderiam estender essa listagem à exaustão. Em obras como Princípios de Economia Política, Estudos do Bem Comum e Constituição Moral e Deveres do Cidadão, é clara e notória a preocupação em persuadir, mas isso não deveria se dar em detrimento incondicional de suas concepções acerca do que admitia ser mais razoável.

A fim de justificar, ainda que de modo muito breve e introdutório as três obras que compõem o núcleo central de fontes a ser considerado nesta pesquisa, cabe mencionar que em Princípios de Economia Política encontra-se uma apresentação analítica e a respectiva defesa do que Silva Lisboa julgou fundamental na obra de Smith. Dividida em três partes, Princípios de Economia Política acrescenta à apresentação e análise das definições e princípios sugeridos por Smith um estudo sobre algumas das críticas dirigidas à Riqueza das Nações, também estabelecendo aproximações e distanciamentos em relação a outras correntes de pensamento então vigentes naquele contexto intelectual, seja de ordem política, econômica ou filosófica em geral, com destaque às ideias fisiocráticas, momento oportuno da referida obra para se identificar com maior clareza conceitual importantes elementos responsáveis por caracterizar a visão de mundo de Silva Lisboa.

Dentre a obra de Silva Lisboa, também foi selecionada a de título Estudos do bem comum e economia política ou ciência das leis naturais e civis de animar e dirigir a geral indústria e promover a riqueza e prosperidade do Estado. Trata-se de dois volumes, a somar mais de quinhentas páginas, cuja publicação se dera entre 1819 e 1820. Para esta pesquisa, esse volumoso trabalho foi tomado para leitura mais verticalizada, que buscou compreender como Silva Lisboa promoveu sua argumentação; uma leitura interessada na possibilidade de identificar a lógica interna daquele texto, a fim de dar continuidade às análises voltadas a compreender a visão de mundo desse autor, conforme interesse de pesquisa já anunciado. Foi a obra mais analisada por esta pesquisa, sobre a qual os respectivos interesses mais se detiveram.

Já Constituição moral e deveres do cidadão, cuja publicação também se deu pela Imprensa Régia entre 1824 e 1825 , embora nem sempre visitada por estudiosos da vida e obra de Silva Lisboa, trata-se de um esforço daquele autor acerca de legar às gerações que davam início àquela nação recém independente uma espécie de catecismo moral, no entanto, composto a partir de estreitos vínculos com a política e a própria economia política, área do 
saber muito privilegiada pela atenção de Silva Lisboa. É possível notar em Constituição moral de deveres do cidadão mais uma tentativa de afastar ou realocar a ciência da economia em relação à moral, ainda que dotada de um propósito explicitamente pedagógico. Ali, a pesquisa depara-se com oportunidade muito promissora e motivadora para se conhecer e analisar a função dos conceitos, que uma vez encontrados na filosofia natural, operam de modo muito presente a compor a racionalidade interna da obra de pensamento de Silva Lisboa. 


\title{
Capítulo 1
}

\section{Acerca de Silva Lisboa e seus escritos: inventários, análises, discursos. Um balanço historiográfico}

\begin{abstract}
Suspeito que José da Silva Lisboa tenha sido, por muito tempo, submetido a uma crítica injusta, cujas raízes podemos encontrar, porventura, na incompreensão de Sérgio Buarque de Holanda, que o identifica a princípios patriarcais inquestionáveis, mas insuficientes para a compreensão de um autor capaz de montar tão complexo quadro da natureza humana, informado por ampla gama de leituras e referências.
\end{abstract}

Pedro Meira Monteiro

O lugar dos escritos de Silva Lisboa na história da cultura intelectual brasileira já rendeu inúmeras páginas e polêmicos debates; farto número de trabalhos cuja produção, como não poderia ser diferente, sempre foi motivada pelo contexto em que se deu. Seria redundância retomar todos eles à exaustão, haja vista que pesquisas anteriores já se deram a esse importante trabalho realizando-o com reconhecida propriedade intelectual. Nas páginas que se seguem, pretendemos destacar as linhas gerais dessas abordagens, que hoje compõem um rico apanhado historiográfico a respeito da obra de Silva Lisboa, tomando-as como ponto de partida para esta pesquisa, sem perder de vista o fato de que todas elas foram sempre históricas e de certa forma responderam a uma determinada demanda contextual, a qual também pretendemos dar relevância e submeter à devida análise.

As primeiras informações sobre Silva Lisboa a que tive acesso encontram-se em um texto voltado a apresentar uma coletânea de escritos desse letrado luso-brasileiro, cuja autoria pertence ao professor Antonio Penalves Rocha, também organizador daquele 
trabalho e estudioso da obra de Cairu ${ }^{32}$. Já decidido a pesquisar mais a fundo o trabalho de Silva Lisboa, voltei aos escritos de Penalves Rocha, desta vez à sua tese de doutorado, $A$ economia política na sociedade escravista, defendida na Universidade de São Paulo em 1989. Voltaria ao mesmo texto em outras ocasiões, acrescido de outras leituras, com a temática de minha pesquisa melhor definida, numa conjuntura que possibilitava observar ali um bom ponto de partida para sistematizar um balanço historiográfico. Iniciava-se assim uma primeira aproximação junto às análises dirigidas à obra de Silva Lisboa e deste modo foi possível retomar, estender e mesmo apontar ressalvas em relação aos pontos mais pertinentes do texto A obra de Cairu na historiografia, que compõe o primeiro capítulo da tese de Penalves Rocha, tendo em vista sobretudo aquilo que diz respeito ao interesse que conduz esta pesquisa.

A se iniciar do modo mais geral, as abordagens sobre a obra de Silva Lisboa podem ser sistematizadas em três fases razoavelmente bem definidas. A primeira delas compreende historiadores do século XIX, cujos trabalhos estiveram direcionados a reunir os escritos de Silva Lisboa e inserir tal autor entre os construtores da nação, os formadores de nossa nacionalidade. Como observou Penalves, em tal ocasião tudo fora feito sem maiores controvérsias, embora já destacando a respectiva importância da obra e de seu autor em relação ao contexto das primeiras décadas do século XIX, marcada principalmente pelo fim do monopólio português, cujo processo histórico em alguma medida contou inclusive com os esforços do próprio Silva Lisboa.

Nessas primeiras abordagens também já está destacado o fato de Silva Lisboa ter sido o responsável por introduzir no Brasil o tema da economia política, bem como o fato de que em seus escritos a determinante relação entre ciência e progresso possuía a finalidade de minar qualquer ideia de revolução. João Manuel Pereira da Silva e Francisco Adolfo Varnhagem ${ }^{33}$ são os nomes que merecem destaque entre essas abordagens

\footnotetext{
${ }^{32}$ A obra consiste em uma coletânea de textos de variada temática, sob autoria de José da Silva Lisboa, precedida por uma introdução, na qual o Professor Penalves Rocha apresenta em linhas gerais a trajetória do Visconde de Cairu, a importância de sua obra e os temas dos respectivos textos a compor o material sob título Visconde de Cairu (1756 - 1835), publicado pela Editora 34 em 2001, cuja organização e introdução fora organizada por Antonio Penalves Rocha.
}

33 A obra de João Manuel Pereira da Silva, Plutarco Brasileiro, foi publicada em 1847, portanto já no Segundo Reinado; dentre a temática abordada, já é possível identificar o problema do ineditismo a ser atribuído a certas concepções de Economia Política no trabalho de Silva Lisboa. Já as concepções de Francisco Adolfo Varnhagem acerca das ideias de Silva Lisboa, encontram-se registradas em História 
inaugurais sobre os textos de Silva Lisboa. O primeiro deles manteve uma postura analítica preocupada com um certo anacronismo ao se estabelecer juízo sobre o ineditismo ou não das ideias de Silva Lisboa, considerou-as em relação ao contexto em que a ciência da economia política se encontrava no período, sendo capaz de reconhecer ali uma boa compreensão a respeito daquela área do conhecimento, então nascente (cf. ROCHA, 1996, p. $13-15)$.

As questões acerca do pioneirismo de Silva Lisboa no que diz respeito à introdução da economia política no Brasil são recorrentes em muitas análises sobre os escritos desse autor, afinal, elas tiveram origem na iniciativa de D. João VI, que ainda em $1808^{34}$ anunciara a criação de um curso sobre economia política no Brasil, o qual deveria estar sob a incumbência de Silva Lisboa. Fato a ser considerado, pois na França, Inglaterra e em Portugal, o mesmo somente seria colocado em prática em 1819, 1825 e 1836, respectivamente. No entanto, o problema está mesmo na ordem da prática, em sua execução, pois o que de fato fora anunciado pelo monarca sediado no Brasil, não foi implementado, levando alguns estudiosos a afirmações que seriam fruto de um malentendido. Para além do necessário esclarecimento de alguns equívocos, como bem fez Penalves, valeria apontar a possibilidade de se perguntar sobre a história das ideias que poderia estar presente no referido curso, perguntar pela formação histórica dessa ciência da economia política, identificando e analisando a obra de Silva Lisboa nesse contexto, nesse ideário, de certo modo na esteira do que havia sugerido, ainda em meados do século XIX, o citado João Manuel Pereira da Silva, ao considerar a obra de Silva Lisboa inserida no cenário de ideias de seu próprio tempo. Como vemos, essa é uma demanda há muito reconhecida, mas que alguns estudiosos de Silva Lisboa por vezes deixaram de lado, embora já se encontrassem mergulhados no século XX. Preocupados com implicações políticas de suas abordagens, permitiram que o discurso precedesse a análise, como veremos a seguir.

Em pesquisa mais recente, o trabalho da historiadora Tereza Cristina

Geral do Brasil, publicada entre 1853 e 1857, bem como em História da Independência do Brasil, de 1875 .

${ }^{34}$ Esta observação entre a proposta de criação e a implantação, de fato, de um curso de Economia Política em terras coloniais antes mesmo dessa referida área do conhecimento receber tal importância na própria metrópole, está realizada já no início da obra de Antonio Penalves Rocha, (cf. ROCHA, 1996, p. 01-02). 
Kirschner $^{35}$ aborda a trajetória política e intelectual de Silva Lisboa tecendo observações a respeito dessas primeiras abordagens sobre a obra do autor. A historiadora lembra a importância do trabalho de Alfredo do Valle Cabral, publicado em 1881, e a exemplo do que conclui Penalves, afirma tratar-se de um rigoroso e completo levantamento dos escritos de Silva Lisboa, ao qual seria acrescentado apenas um texto encontrado no Arquivos Nacionais da Torre do Tombo, além de periódicos e folhetos a serem somados ao levantamento finalizado por Helio Vianna, em 1945, desta vez, voltado às publicações periódicas de Silva Lisboa. Hoje, a quase totalidade da obra de Silva Lisboa encontra-se na Biblioteca Nacional do Rio de Janeiro, na seção de obras raras (cf. KIRSCHNER, 2009, p. 11).

Indo além das observações de Tereza Cristina Kirschner, Penalves já havia chamado a atenção para o fato de que a obra de Alfredo do Valle Cabral não se resume a um levantamento das obras de Silva Lisboa, ou mesmo na inserção desse autor entre os formadores da nacionalidade brasileira; Alfredo do Valle havia destacado as relações entre as ideias de Silva Lisboa e Adam Smith, sendo possível identificar um primeiro viés analítico que deixaria heranças aos estudos posteriores, quando historiadores e economistas, influenciados por Alfredo do Valle, passariam a explorar a aproximação entre a obra de Silva Lisboa e o liberalismo, a despeito deste último não ter empregado em sua análise o termo liberalismo, como tão bem notou Penalves. Assim, a compor um primeiro momento dessa vertente mais analítica, o trabalho de Alfredo do Valle se diferenciou daqueles realizados ainda no século XIX, uma vez que estes limitaram-se a inventariar a obra de Silva Lisboa e inseri-lo no quadro de formação da intelectualidade nacional.

Sobre os trabalhos produzidos no século XIX, podemos concluir sem grandes distanciamentos em relação às análises mais recentes aqui consultadas, como a desenvolvida por Tereza Cristina Kirschner e sobretudo a de Penalves Rocha. Mesmo a produção que se deu nas primeiras décadas do século XX pode ser tratada sem maiores polêmicas, pois as análises e críticas tecidas até então estão argumentadas de modo bastante claro e razoável. Assim é o caso do português Moses Bensabat Amzalak, cujo texto publicado em 1928 é tido como uma cuidadosa abordagem da obra de Silva Lisboa,

35 A referência completa do texto mencionado encontra-se indicada na bibliografia, bem como aquelas relativas aos trabalhos de Alfredo do Valle Cabral e Hélio Vianna, cujos trabalhos de pesquisa também estão mencionados na obra de Penalves. Por vezes, foi pertinente explicitar as diferentes abordagens que a historiografia mais contemporânea, expressa a partir do trabalho de Antonio Penlaves Rocha e de Tereza Cristina Kirschner, retomaram essas primeiras análises sobre a obra de Silva Lisboa. 
tomando-a sob uma perspectiva histórica, em especial a história do pensamento econômico português. Há outros exemplos dessa primeira metade do século XX, como a obra de Braz do Amaral $^{36}$, que instrumentalizou-se das ideias de Silva Lisboa para servir ao discurso a que esteve alinhado em uma batalha intelectual estreitamente relacionada às questões dos anos trinta. Ali, é possível notar que os escritos de Silva Lisboa foram retomados com a pretensão de compor um discurso contrário a então política intervencionista e mesmo protecionista, desencadeada a partir da década de trinta.

Mais adiante, em publicações de 1944 e 1956, respectivamente, Augusto Machado e Alceu Amoroso Lima ${ }^{37}$, interessados nas ideias econômicas de Silva Lisboa, foram autores de trabalhos a que Penalves Rocha tece duras críticas, atribuídas à imprecisão das respectivas pesquisas; o segundo teria ido além das imprecisões, ao inaugurar análises que identificariam na obra de Silva Lisboa ideias precursoras dos trabalhos de economistas renomados, tais como Ford, Taylor e Stakhanov (cf. ROCHA, 1996, p. 17 - 20). Ainda poderíamos citar o trabalho de José Soares Dutra, de 1943, cujas considerações a Silva Lisboa foram classificadas por Penalves Rocha como "disparatadas"; o que não ocorre em se tratando da análise de Hélio Vianna, debruçado sobre a relação entre Silva Lisboa e a imprensa, que embora não desperte o interesse das abordagens preocupadas com o problema da economia, ajuda a compreender a visão de mundo mais geral do autor, interessando assim a esta pesquisa, sobretudo quando faz menção aos aspectos cientificistas.

A historiadora Tereza Cristina Kirschner acompanha e até enfatiza mais do que Penalves a crítica que fez este último a algumas análises também produzidas em meados do século XX. Como sabemos, por razões ligadas ao contexto histórico e ao viés político ao qual estiveram alinhados, alguns estudiosos chegaram até mesmo a depreciar o trabalho de Silva Lisboa, não a partir de seu conteúdo, mas sim de algumas posturas políticas de Cairu. Esse é o caso do historiador Sérgio Buarque de Holanda, cujo merecido

${ }^{36} \mathrm{O}$ mencionado trabalho de Moses Bensabat Amzalak responde pelo título Do Estudo e da Evolução das Doutrinas Econômicas em Portugal, publicação de 1928. A suas análises podem ser somadas aquelas encontradas sob título "José da Silva Lisboa, o Visconde de Cairu (1756-1835), publicado na Revista Brasileira. Já o mencionado trabalho de Braz do Amaral, encontra-se na Revista do Instituto Histórico e Geográfico Brasileiro, número 170, publicado em 1935. Ambas as referências, completas, encontram-se na bibliografia.

${ }^{37}$ O texto de Augusto Machado foi publicado em 1944, no Rio de Janeiro, pelo Jornal do Comércio; já o de autoria de Alceu Amoroso Lima teve por base uma conferência proferida em 1936. As referências estão apontadas na bibliografia. 
reconhecimento acerca da envergadura de sua obra contribuiu para imprimir ao trabalho de Silva Lisboa caracterizações que se repetiram e influenciaram um sem número de leituras e estudos posteriores, e que já há algum tempo demandam reconsiderações por parte dos estudiosos dos escritos de Cairu.

Ao se tomar os pareceres de Sérgio Buarque de Holanda a respeito do trabalho de Silva Lisboa, não se deve deixar de lado o fato de que inicialmente foram escritos para um artigo cujo fim era refutar o tom bajulador com que Alceu de Amoroso Lima tratou a obra e a figura de Cairu no já mencionado texto, desdobramento de uma conferência proferida no Rio de Janeiro, em $1936^{38}$. Por sua vez, as críticas de Sérgio Buarque de Holanda foram publicadas no Correio da Manhã, em 1946. Seus argumentos ganharam maior notoriedade quando foram inseridos na segunda edição do clássico Raízes do Brasil $^{39}$, onde Silva Lisboa foi duramente criticado por compartilhar a ideia generalizada acerca da primazia da inteligência sobre o trabalho manual; de que este possui menor dignidade se comparado às atividades do espírito, para dizer ao modo de Sérgio Buarque. As críticas são fundamentadas em problemas que vão da má tradução ao mau uso que fez Cairu de conceitos atribuídos a Adam Smith. Visto assim, as ideias de Silva Lisboa teriam nascido já pertencendo ao passado:

E também parece certo que o autor dos Estudos do bem comum, a despeito de seu trato com economistas britânicos, não contribuiu, salvo nas aparências e superficialmente, para a reforma das nossas ideias econômicas. Pode dizer-se que, em 1819, já era um homem do passado, comprometido na tarefa de, a qualquer custo, frustrar a liquidação das concepções e formas de vida relacionadas de algum modo ao nosso passado rural e colonial (HOLANDA, 1995, p. 85).

A partir do trecho citado acima, Sérgio Buarque estende as críticas em longa nota de rodapé, cuja intenção primeira é refutar o já citado artigo de Alceu Amoroso Lima, que atribuíra aos Estudos do bem comum não somente atualidade, mas também certa autonomia do pensamento de Silva Lisboa em relação aos textos que este autor havia tomado como ponto de partida. Na sequência, as críticas de Sérgio Buarque passam da

\footnotetext{
${ }^{38}$ A publicação da conferência proferida por Alceu Amoroso Lima de 1936 se deu primeiramente em 1944, para posterior e notória reprodução na ocasião de uma $2^{a}$ edição de Princípios de Economia Política, datada de 1956.

${ }^{39}$ A abordagem inicial a respeito das mencionadas concepções de Silva Lisboa foram publicadas no Correio da Manhã, em 1946, retomadas na segunda edição de Raízes do Brasil, publicada em 1947. As críticas ao pensamento de Silva Lisboa encontram-se no terceiro capítulo, Herança Rural.
} 
obra ao homem Silva Lisboa:

É semelhante empenho que se espelha, com perfeita nitidez, em suas opiniões filosóficas, em suas genuflexões constantes diante do Poder e, sobretudo, em sua noção bem característica da sociedade civil e política, considerada uma espécie de prolongamento ou ampliação da comunidade doméstica, noção essa que se exprime, com a insistência de um leitmotiv, ao longo de toda a sua obra (HOLANDA, 1995, p. 85).

O que Sérgio Buarque está a notar e criticar com ênfase na obra de Silva Lisboa é o apelo que faz este autor a uma lei moral calcada sobre o modelo da família patriarcal, que segundo Cairu deveria reger de modo inflexível a vida política e sobretudo a relação entre governantes e governados, conferindo assim uma espécie de harmonia social e afastando qualquer anseio revolucionário. Tais comentários não foram negligenciados pelas pesquisas posteriores, também interessadas na obra de Silva Lisboa. Embora tenha anunciado limitar-se às abordagens relacionadas à economia, Penalves Rocha faz ponderada, mas elucidativa observação sobre as críticas de Sérgio Buarque a Alceu Amoroso Lima:

Em suma, ao opor-se à louvação desmesurada que a obra de Cairu havia recebido desde a conferência de Alceu Amoroso Lima, Sérgio Buarque de Holanda colocou-a dentro da época em que foi gerada, situando os seus fundamentos sociais. Assim mesmo, deixou transparecer um certo descaso para com os escritos de Cairu e os subvalorizou ao compará-los com os trabalhos de Rodrigues de Brito e Veloso de Oliveira, ou seja, não chegou a vê-los com isenção de ânimo (ROCHA, 1996, p. 22).

O trabalho de Afonso Arinos de Melo e Franco já havia notado de modo bastante apropriado as análises um tanto apaixonadas sobre a obra de Silva Lisboa. Citado literalmente por Kirschner, mas não por Penalves, Afonso Arinos identificou exageros na exaltação e na depreciação do trabalho de Silva Lisboa, que de modo geral fora louvado no final do século dezenove por simbolizar a cultura intelectual brasileira, mas posteriormente criticado com certa voracidade por renomados acadêmicos, tais como Sérgio Buarque de Holanda e Octavio Tarquínio de Sousa:

Exagero para cima e para baixo, no louvor e na crítica. ... Cairu passou a ser considerado oficialmente um alto símbolo da cultura nacional, a ponto de dar seu nome à instituição do governo incumbida de elaborar a Enciclopédia Brasileira. Convenhamos que não há fortes justificativas para isto. Como reverso desta medalha, no entanto, historiadores há, e dos mais autorizados como os Srs. Sérgio Buarque de Holanda e Octavio Tarquínio de Sousa que, permitindo-se a expressão, negam a Cairu pão e água. Consideram-no um velho adulador, um áulico sem maior interesse, 
e, em matéria teórica, um repetidor, sem nenhuma originalidade de noções e de conceitos cediços (FRANCO, 1947, p. 87).

Todas essas observações mais extremadas acerca da obra de Silva Lisboa e sobretudo a respeito da biografia política desse autor, de fato, não contribuem muito para a elucidação de questões pertinentes à História Intelectual, questões ligadas às ideias acadêmicas de Silva Lisboa, a partir das quais o autor buscava compreender o Brasil e mesmo intervir nas diretrizes históricas daquela jovem nação; questões muito efervescentes em finais do século XVIII e inícios do século XIX, fossem elas de ordem econômica, política ou social. Tais análises por vezes parecem tratar-se de uma história focada no julgamento do intelectual, em prejuízo da preocupação analítica sobre sua respectiva obra.

Admite-se que não seja possível a completa isenção do pesquisador em relação a seus próprios posicionamentos sobre economia, sociedade ou política no momento de analisar o passado; suas respectivas premissas estão presentes nas mais variadas formas e se manifestam em inúmeros momentos da pesquisa, portanto, é preciso estar atento ao difícil, mas necessário esforço de considerar o intelectual em seu contexto, zelando pela finalidade de que isso possa contribuir, primeiramente, para elucidar as análises a respeito de sua obra. $\mathrm{O}$ foco desta pesquisa foi projetado sobre a produção do intelectual, produção esta que não é a sua posição política, de modo exclusivo, mas inclusive ela, a ser tratada enquanto mais uma faceta a ser investigada e considerada no processo de compreensão e análise de suas ideias e concepções, a partir das quais o autor compreendeu, analisou e interferiu na sociedade em que viveu. Conforme o que se pretendeu aqui, as atenções residiram sobre sua obra de pensamento e a relação desta com o contexto de ideias no qual esteve inserida. Mais do que concordar com as críticas de Penalves e Kirschner a respeito de algumas observações "sem isenção de ânimo", coube notar que muitas vezes a apresentação dessas análises, cuja autoria é de reconhecido comprometimento com o rigor e a profundidade, poderiam ter ido além, tendo em vista os intelectuais que se propuseram à tal realização.

O artigo de Zenith Mendes Silveira, publicado em 1956, e do mesmo ano, o trabalho de Nogueira de Paula, ambos comentados por Penalves Rocha, apontaram outras possibilidades analíticas a respeito da obra de Silva Lisboa ${ }^{40}$. O primeiro relaciona a obra

\footnotetext{
${ }^{40}$ As referências para o artigo de Zenith Mendes Silveira e o texto de Nogueira de Paula encontram-se na bibliografia. Este último comenta capítulo a capítulo da obra Princípios de Economia Política, de José da
} 
de Silva Lisboa ao liberalismo econômico, investigando nela a trajetória desse conceito e ressaltando o que há de específico. Deste modo, nota que a realidade material de Silva Lisboa impôs especificidades de um liberalismo que se colocasse prioritariamente contra o sistema colonial. Já o segundo, em tom mais elogioso, escreveu o texto introdutório e comentou capítulo a capítulo a edição de 1956 dos Princípios de Economia Política. Nogueira de Paula viu Silva Lisboa como um erudito de grande cultura científica, mas, segundo Penalves, não esteve preocupado em considerar o contexto em que Cairu escreveu seus textos, conferindo assim maiores atenções ao que entendeu ser a sua herança, chegando a sugerir, com muito pouca capacidade de convencimento, alguma influência de Silva Lisboa no trabalho do economista David Ricardo (cf. ROCHA, 1996, p. 23).

No final da década de cinquenta, foi publicado o que Penalves Rocha classificou de "um ponto alto em matéria de caracterizações disparatadas sobre a figura de Cairu": o trabalho de Vilhena de Morais, O Perfil de Cairu ${ }^{41}$. Temos aí Silva Lisboa precursor da teoria do valor da inteligência, depreendendo a partir disso que Silva Lisboa coloca-se contra Marx; tem-se também Silva Lisboa precursor de Augusto Comte, ao falar sobre economia política em termos de igualdade à física social e dinâmica civil. Ainda é possível ir além nessa obcecada investigação pelo que poderia haver de precursor na obra de Silva Lisboa, pois tal postura se repete e se intensifica no trabalho de Elísio de Oliveira $^{42}$, publicado em 1959, onde está sugerido que Silva Lisboa antecipou Keynes, Rossevelt, Marx e Engels (cf. ROCHA, 1996, p. 24).

Contudo, realizadas as devidas e justas críticas às análises apressadas e mesmo exageradas sobre a obra do intelectual luso-brasileiro, mais uma vez é possível notar em considerável parte da historiografia uma certa carência analítica em relação a problemas de uma simplicidade que pode ser apenas aparente. Embora não os coloque em equivalência com a economia política, em Estudos do Bem Comum, como afirmou Vilhena de Moraes, muito criticado por Penalves, Silva Lisboa utiliza sim conceitos tais como física social e dinâmica civil, e seguramente tal instrumental teórico exerceu alguma função cognitiva em

Silva Lisboa, quase sempre em tom elogioso; não considerou a contento o contexto em que a obra foi escrita, preocupando-se também em identificar possíveis heranças da obra de Cairu, quando então sugere ter influenciado David Ricardo.

${ }^{41}$ MORAES, V. O perfil de Cairu. Rio de Janeiro, 1968

${ }^{42}$ MELCHIOR, Elísio de Oliveira. Visconde de Cairu, sua vida e sua obra. Rio de Janeiro, 1959. 
sua obra de pensamento ${ }^{43}$. Tal presença indica a necessidade de esquivar-se de conclusões apressadas, sejam aquelas que a qualquer custo buscaram elementos precursores da economia ou da sociologia, sejam aquelas que preferem não considerar qualquer análise pormenorizada de determinados conceitos, relegando a planos secundários ideias que certamente atuaram nas análises elaboradas pelo autor estudado. Tais conceitos e ideias não só estiveram inseridos, como muitas vezes foram centrais para toda aquela produção, releituras ou mesmo reprodução de saberes, afinal, também compunham aquele cenário intelectual, no qual foram elaborados e junto ao qual aturam.

Já em finais da década de sessenta temos o trabalho de Antonio Paim, Cairu e o Liberalismo Econômico, um texto de história das ideias, realizado com rigor e sem perder o referencial das mudanças ocorridas no processo histórico ligado ao mundo material ${ }^{44}$. Mais uma vez, tomou-se a obra de Silva Lisboa para ser entendida no quadro da Economia Política da época e destacar o que nela havia de específico; além desse esforço, nota-se também a preocupação em avaliar a importância do trabalho de Silva Lisboa no processo de incorporação da elite letrada luso-brasileira no pensamento moderno. Nessa direção, conclui Paim que Silva Lisboa, no compasso dos economistas europeus do período, associou a economia política à ética, para então tomá-la no Brasil como uma ciência normativa da sociedade. (cf. ROCHA, 1996, p. 25).

Dos meados da década de setenta, Penalves Rocha destaca dois trabalhos bastante diferenciados. O primeiro é o de Dea Fenelon, Cairu e Hamilton - um estudo comparativo $^{45}$, o qual prezou pelo rigor, extensão bibliográfica e coerência metodológica, concluindo que Silva Lisboa e Hamilton foram discípulos de Smith, porém, agiram de modo diferente, sendo o primeiro um pensador que acreditava na ideia da Mão Invisível e o segundo nas benesses da industrialização; posturas que a autora atribui à relação entre as ideias e as bases materiais. Embora a pesquisa tenha sido corretamente elogiada por Penalves, em se tratando dos autores comparados, bem como da problemática a que seus

\footnotetext{
${ }^{43}$ Ver Estudos do Bem Comum, Introd. pg. XIII.

${ }^{44}$ O trabalho de Paim foi publicado 1968, sob título Cairu e o Liberalismo Econômico. No trecho em que Penalves Rocha comenta a obra de Antonio Paim, há uma muito breve observação lembrando que o trabalho de Paim é uma história das ideias em stricto sensu, mas com ressalva de que as ideias não possuem historicidade própria, haja visto que refletem mudanças ocorridas no mundo material

${ }^{45} \mathrm{O}$ trabalho de Dea Ribeiro Fenelon, Cairu e Hamilton - um estudo comparativo, foi sua tese de doutorado, apresentada à Faculdade de Filosofia e Ciências Humanas da Universidade Federal de Minas Gerais, em Belo Horizonte, no ano de 1973.
} 
textos foram submetidos, Celso Furtado foi quem lançou a proposta. Tanto é assim que Fenelon inicia seu trabalho citando Formação Econômica do Brasil.

Enquanto o trabalho de Fenelon pode seguramente ser bem avaliado, o segundo é passivo de críticas. Trata-se de uma apresentação escrita por José de Almeida à reedição de Estudos do Bem Comum $^{46}$, de 1975. Novamente, os escritos de Silva Lisboa não foram tratados de modo contextual; há novamente inúmeras afirmações sobre elementos precursores, chegando Almeida a apontar na obra do luso-brasileiro a identificação e mesmo a correção de erros conceituais cometidos por Smith, Malthus e Ricardo. Antes de classificar as considerações de José de Almeida como "desnorteadas", Penalves Rocha ainda lembra que na mesma apresentação Silva Lisboa foi tomado como pioneiro em criticar a teoria do valor, que até então sequer existia (cf. ROCHA, 1996, p. 27).

A se deter com atenção sobre o trabalho de Dea Fenelon, em especial sobre os objetos e objetivos de sua pesquisa, nota-se que a autora teve como premissa teórica a importância do estudo das formas de pensamento na compreensão do complexo social, sobretudo se consideradas diretamente ligadas ao processo histórico, ou seja, à crise geral do Antigo Regime. Mas além de projetar as atenções ao estudo das formas de pensamento, ainda na introdução de seu trabalho há algo com o que se alinha a pesquisa que se pretendeu realizar aqui. Justamente no momento em que nos chama a atenção para os problemas das generalizações apressadas, formuladas por estudiosos menos cuidadosos que se colocam a comparar formas de pensamento de autores diferentes, a exemplo da comparação entre Hamilton e Cairu, a mesma autora também destaca a devida importância e a sua própria intenção em identificar e isolar, a partir de seu estudo comparativo, variáveis que ultrapassam fronteiras nacionais. Apoiada numa citação encontrada em Combats pour l'Historie, de Lucien Febvre, Dea Fenelon afirma que historiadores comparam para substituir singulares por plurais (cf. FENELON, 1973, p. 8).

Os elementos que esta pesquisa pretende identificar e analisar na obra de pensamento de José da Silva Lisboa são muitas vezes da ordem do geral, pertencentes a um contexto de ideias que não pode ser compreendido de modo isolado, recortando questões ligadas à ordem política, social ou econômica. Isso em hipótese alguma significa afirmar que determinadas conjunturas de ordem política, social e econômica não tenham

\footnotetext{
${ }^{46}$ ALMEIDA, José (org.); LISBOA, José da Silva. Estudos do Bem Comum e economia política. Brasília:
} IPEA, 1975. 
atuado no modo de recepção e aplicação dos conceitos por ele empregados, os quais, a dizer como Dea Fenelon, também não foram determinados apenas pelas linhas nacionais. É justamente nesse encontro em que identificaremos os pontos mais interessantes da apropriação de conceitos que Silva Lisboa tomou junto à filosofia natural e os aplicou na compreensão da política, sociedade e economia em que viveu, os anos da crise geral do Antigo Regime.

Caberia mencionar, embora de modo muito breve, que o trabalho de Dea Fenelon identificou em Hamilton e Silva Lisboa o problema da consolidação da unidade nacional enquanto principal referência para a aplicação das ideias liberais, provenientes da obra de Adam Smith. Ambos, Hamilton e Silva Lisboa, eram partidários do liberalismo encontrado em Wealth of Nations, e ambos, inseridos em seus respectivos contextos, tiveram a unidade nacional como questão central no momento em que buscaram aplicar as ideias de Smith em dois casos consideravelmente distintos, cujo desenrolar histórico se deu na América durante o despontar do mundo contemporâneo. Analisando essas aplicações conceituais, aprendidas junto às ideias liberais ou mesmo iluministas, para dizer de modo mais geral, Fenelon identificou o que sugestivamente preferiu chamar de formas de pensamento e ação, através das quais os autores por ela estudados participaram na organização de suas respectivas nações, sobretudo nos campos da política e da economia.

Acerca das formas de apropriação e adaptação das ideias liberais empreendidas por Silva Lisboa, Dea Fenelon reconstitui e destacou o que denominou de elementos da ideologia dominante, tais como a defesa de uma ação intervencionista do governo que fosse compatível com o interesse dos indivíduos, cuja medida deveria sempre levar em conta a temida possibilidade de reimplantar monopólios; no entanto, a historiadora também destacou que nos escritos de Silva Lisboa há explícito combate aos liberais exaltados, ansiosos pela República. A Revolução Francesa, que para os exaltados seria o horizonte, segundo a ótica de Silva Lisboa tratava-se da expressão máxima do caos e da desordem a que poderia levar a implantação de tal sistema de governo.

Deste modo, Silva Lisboa tinha a monarquia como a essência do sistema do qual pretendia expurgar as práticas monopolistas e o retrógrado pacto colonial. Em defesa dos interesses de comerciantes e senhores de terras brasileiros, Silva Lisboa buscou argumentos liberais para um alinhamento econômico junto aos ingleses, sem com isso alterar a ordem política que lhe era favorável; daí seus esforços na defesa de uma monarquia constitucional. Ainda que contrário às medidas encaminhadas pelas Cortes, a 
ideia de independência política foi por ele postergada até que as últimas possibilidades fossem esgotadas, e quando então ela se colocou na ordem do dia, ainda expressava nítidos apegos à herança absolutista, chegando a apoiar D. Pedro no momento em que determinou a dissolução da Assembleia em 1823, bem como receber com entusiasmo a Constituição outorgada pelo mesmo imperador em 1824, sob "inspiração divina” (cf. FENELON, 1973, p. $151-152)$.

Em suas conclusões, Fenelon tece comentários acerca da argumentação de Silva Lisboa em comparação a Hamilton:

... Sua argumentação é sempre rebuscada, passadista, cheia de lições ou preocupações morais e religiosas, bastante incompatíveis com suas ideias avançadas de economia e revelando, como Hamilton, bastante tímido, medroso, sempre receoso das novidades, das reformas, sempre pronto a reagir e condenar toda espécie de mudança: o perfeito defensor do "status quo" (FENELON, 1973, p. 153).

Ainda que muito razoáveis, os apontamentos acima poderiam estar acompanhados de alguma análise, como aliás tantas vezes e tão bem fizera a autora ao longo do mesmo trabalho em referência neste momento. A citação acima recorre a conclusões pertencentes a lugares um tanto comuns e que pouco elucidam a complexidade inerente à obra do autor em questão. Considerando que Silva Lisboa defendia posições intelectuais incompativeis, que reunia ideias avançadas de economia a preocupações morais e religiosas, surge a possibilidade de questionar se tal incompatibilidade se constrói no interior da obra de pensamento de Silva Lisboa, analisando os conceitos por ele adotados e seus respectivos significados em relação ao contexto intelectual em que esteve inserido.

Como já foi notado, se considerarmos o contexto de ideias em que esteve inserida a obra do próprio Adam Smith, constataremos que suas ideias acerca da economia compartilham uma determinada visão de mundo na qual também estiveram presentes conceitos ligados à metafísica ou mesmo à religiosidade (cf. COHEN; WESTFALL, 2002, p. 397 - 448). Sendo assim, quando tal ideário foi apropriado por um homem de postura dita conservadora, a exemplo de Silva Lisboa, os mais variados aspectos de sua respectiva obra, seja a respeito da avançada economia que propunha, ou seus anseios mais conservadores no que diz respeito à política, podem apresentar uma determinada compatibilidade que não foi alcançada apenas através da retórica, mas sim através de uma coerência interna àquele contexto de ideias, que estudiosos do presente devem buscar 
compreender de modo mais aprofundado. As leituras apontam que a identificação e análise de conceitos ligados à filosofia natural, muito presentes na obra de Silva Lisboa, podem ajudar nessa compreensão.

Já em sua tese de doutorado, A Economia Política na Sociedade Escravista, Penalves Rocha afirmou estar analisando a obra de Silva Lisboa a partir de um interesse ligado à história do pensamento econômico; um estudo da ideologia econômica ${ }^{47}$. Como já visto neste capítulo, que é uma espécie de balanço historiográfico dos escritos sobre Silva Lisboa, Penalves vê com ressalvas as análises anteriores que menosprezaram a obra desse letrado luso-brasileiro em decorrência de sua estreita ligação com as autoridades do Estado português e mesmo nacional, já no início do Império, a partir de 1822. Assim, Penalves toma os textos de Silva Lisboa como importante material para a compreensão do nascimento da economia política no Brasil, como uma fonte histórica para um estudo acerca das relações entre essa ciência e as transformações ocorridas no império português, sobretudo aquelas posteriores a 1808.

Como implicação contemporânea a seu estudo, Penalves Rocha aponta a insuficiência de abordagens ligadas à história do pensamento econômico brasileiro para subsidiar debates ligados às teorias do desenvolvimento, de importância marcante sobretudo a partir de meados do século vinte. Já por parte exclusiva dos historiadores, o descaso em relação aos textos de Silva Lisboa parece ser proveniente do caráter laudatório de seus escritos, de linguagem e conceitos em acordo com as ciências morais e políticas do período, o que entende ser uma recusa dos estudiosos dessa área do saber em classificar os escritos de Silva Lisboa como documentos, fontes para a pesquisa em História:

No final das contas, ao negar-lhes a condição de documentos, foi perdida uma oportunidade para se compreender alguns aspectos da história do Brasil, relacionados tanto com a história da cultura letrada nacional - o significado da introdução da Economia Política numa sociedade escravista -, quanto com a história política - o papel que a Economia Política desempenhou na construção do Estado nacional (ROCHA, 1996, p. 08).

A partir dessa preocupação, a obra de Silva Lisboa foi tomada por Penalves

\footnotetext{
$47 \mathrm{O}$ autor classifica o seu estudo como um "estudo de ideologia, mais especificamente da ideologia econômica". Ainda alerta para a "suposta antinomia entre ciência e ideologia", fazendo crítica à pretensão de alguns economistas de que tal área de pesquisa poderia mesmo desligar-se de sua herança junto à Economia Política, perdendo suas características de ciência social e tornando-se algo técnico e não ideológico (cf. ROCHA, 1989, p. 10).
} 
Rocha para estudos que, em alguma medida, buscaram reverter esse quadro de abordagens. O intuito foi debruçar-se sobre a obra de Silva Lisboa e analisar a economia política ali presente em sua "positividade", atentando-se àquilo que o pensamento econômico brasileiro criou e a influência que exerceu no seu tempo. Pois este foi justamente um dos intentos desta presente pesquisa: tomar os escritos de Silva Lisboa em sua positividade, desta vez perguntando pelas implicações de teorias e conceitos provenientes da filosofia natural, os quais incidiram sobre uma dada cosmovisão que em boa medida orientava suas análises a respeito do Brasil. Uma vez que a obra de Cairu comporta um conjunto lógico de ideias, é justamente a relação dessa logicidade com a filosofia natural o que a este trabalho interessou.

Após tratar as condições em que se difundiu a economia política no Brasil ao longo das décadas iniciais do século XIX, examinar os aspectos formais do pensamento de Silva Lisboa, bem como sua concepção de economia política, a tese de Penalves Rocha ainda apresenta os principais temas abordados por Cairu, o espírito prático com que buscava relacionar o saber teórico às questões brasileiras, para então finalizar analisando a tão polêmica acomodação dos princípios antiescravistas da economia política àquela situação brasileira, profundamente ligada ao trabalho escravo. Dotado de considerável erudição, a pesquisa de Penalves submeteu a obra de Silva Lisboa ao rigor acadêmico, o que se faz possível notar a partir do trecho em que o historiador cotejou de modo cuidadoso a tradução realizada por Silva Lisboa de um texto de Smith, para então concluir que alguns equívocos do luso-brasileiro estavam relacionados à leitura que o mesmo havia feito de uma outra tradução, esta do inglês para o francês, e que por fim viria a comprometer o texto do próprio Silva Lisboa:

... Com efeito, Adam Smith argumentou que a divisão do trabalho proporcionaria o aumento da capacidade produtiva se fosse empregada a skill, que permite utilizar a palavra habilidade como sua correspondente em português, a dexterity, que pode ser traduzida por destreza e o judgement, que poderia ser traduzido por discernimento, mas não por inteligência. [...]

Entretanto, não é difícil entender o motivo que levou Silva Lisboa a fazer essa tradução. Nos seus livros são encontradas algumas referências elogiosas a uma edição francesa do Riqueza das Nações, cuja tradução e comentários foram feitos por Germain Garnier. Nela Garnier verteu para o francês as palavras skill, dexterity e judgement como "habilité, adresse e intelligence. Não há dúvida que José da Silva Lisboa acompanhou a tradução de Garnier (ROCHA, 1989, p. 43).

Esta é a passagem a partir da qual Sérgio Buarque de Holanda teceu críticas, 
aliás justas, à tradução realizada por Silva Lisboa, e que acima encontra-se exemplificada a partir de trecho rigorosamente analisado por Penalves Rocha. Se a citação acima demonstra trabalho de exegese ao abordar o problema da difusão da economia política no Brasil, nos capítulos seguintes do trabalho de Penalves Rocha encontram-se análises que vão desde a identificação dos eixos temáticos da obra de Silva Lisboa, passando pelas questões acerca de como a economia política está exposta ali, perguntando sobre o lugar de suas ideias na História do Brasil e chegando ao que entendemos aqui ser o ponto alto de sua tese: a relação que é concebida por Silva Lisboa entre a escravidão e a economia política, quando considerado o caso brasileiro. Segundo Penalves Rocha, a abordagem da doutrina escravista conforme elaborada por Silva Lisboa passava por dois motes centrais:

Em primeiro lugar, postulou a inevitabilidade da escravidão nas colônias americanas em virtude do "clima ardente"; em segundo lugar, argumentou sobre a impossibilidade de abolir a escravidão pelas condições geográficas. Restava, por conseguinte, a possibilidade de mitigá-la e, como já se sabe, para Cairu a mitigação da escravidão é também um caminho para o progresso das artes, da civilização e da estabilidade política (ROCHA, 1996, p. 140).

Mas como então conciliar essa doutrina apresentada acima aos princípios em que se baseava, retirados da economia política? Afinal, os teóricos dessa ciência nascente eram radicalmente contrários ao escravismo. Segundo Penalves Rocha, Cairu esteve com os teóricos da economia política ao entender que o trabalho escravo é antieconômico, mas a "energia que a economia escravista brasileira apresentava" impedia-o de segui-los na íntegra. Desta forma, a escravidão não poderia ser imediatamente recusada por Silva Lisboa, sendo a ideia de mitigá-la uma saída para conciliar os princípios teóricos que compartilhava à realidade do modo de produção que imperava no Brasil. Ainda segundo Penalves Rocha, mitigar a escravidão a partir do Estado de certa forma "acomodava à sociedade em que vivia os pressupostos teóricos da economia política" (ROCHA, 1996, p. 142). Visto assim, as condições materiais de produção, impostas pelo escravismo, impunham também os limites sobre a economia política que Silva Lisboa estava a defender.

Dentre tanto, é o quinto capítulo o que mais traz elementos de interesse a esta pesquisa. Intitulado Uma análise do Brasil, está voltado a compreender os moldes com que os escritos de Silva Lisboa sobre economia política estiveram ligados às ciências morais e políticas do século XVIII, como atuaram nas análises desse autor a respeito do 
Brasil. Para tal, o pesquisador tomou quatro eventos que segundo ele foram tratados por Silva Lisboa como "realizações concretas de certos pressupostos teóricos: a Abertura dos Portos, o Alvará de $1^{\circ}$ de abril de 1808 , os Tratados de 1810 e a elevação do Brasil a Reino Unido de Portugal" (ROCHA, 1996, p. 101).

O que chama a atenção ao interesse desta pesquisa é o fato de que o historiador começa a análise a partir do uso que Silva Lisboa fez da ideia de sistema, no intuito de discorrer a respeito da condição colonial. Penalves Rocha tece apontamentos a respeito da genealogia do termo, destacando sua utilização entre os fisiocratas, portanto, já relacionado a questões econômicas. Preocupado com o que chamava de Bem Comum, Silva Lisboa entendia a relação entre Portugal e seus domínios como um sistema colonial, ao qual tecia críticas porque nele identificava leis que em nada contribuíam para o interesse de todos os envolvidos. Embora as tenha identificado, Penalves Rocha não analisa na explicação formulada por Silva Lisboa as relações ali estabelecidas entre determinada terminologia e a filosofia natural, a exemplo do que também se dá com o emprego da metáfora mecanicista, que compara o sistema a uma máquina. Tanto sistema, quanto máquina, são termos e mesmo conceitos recorrentes e de primordial importância para a filosofia natural do período. Silva Lisboa visa compreender a relação entre o que chamamos metrópole e colônia a partir de recursos conceituais que encontram-se naquele que para ele é um dos mais importantes referenciais do conhecimento humano: a filosofia natural.

Ainda no mencionado capítulo, Penalves Rocha lembra que Silva Lisboa tinha a Revolução Francesa como uma catástrofe, porém, teria sido esse mesmo acontecimento histórico o mais notório responsável por mudar o arranjo de coisas, impulsionando transformações históricas a partir dos males causados pela onda revolucionária. Em sua análise, destaca que Silva Lisboa tinha a Revolução Francesa como uma ação da Providência Divina, cujo propósito era o de restabelecer a ordem civil e cosmológica. Notamos novamente o quanto Silva Lisboa compartilha uma cosmologia na qual o mundo, e portanto também a sociedade que nele se encontra, pode ser observado segundo um mecanicismo que concebe a interferência divina no funcionamento da máquina, a exemplo do que pensavam muitos filósofos naturais de seu tempo, sobretudo os ainda religiosos ${ }^{48}$.

\footnotetext{
48 Abordagens voltadas a essa temática, a aproximação entre a filosofia natural e questões ligadas à religiosidade, podem ser encontradas em trabalhos já não mais tão recentes, a exemplo de Essays on the context, nature, and influence of Isaac Newton's theology, comportando artigos organizados por James
} 
Conforme a análise de Penalves Rocha, para Silva Lisboa a Revolução seria então um "castigo divino aos que não acreditavam na ordem natural e produziu uma série de efeitos que não tinham nenhuma relação com as intenções dos seus protagonistas de implementar a liberdade e a igualdade" (ROCHA, 1996, p. 103).

Como vemos, está presente na cosmologia de Silva Lisboa uma gama de elementos suficientes para que seus escritos possam ser submetidos a questionamentos que até então foram anunciados, mas não analisados em profundidade. No capítulo Uma análise do Brasil, Penalves Rocha já levanta uma série de conceitos e relações efetuadas por Silva Lisboa a partir dos quais esse historiador tece rica análise e comentários segundo o interesse de sua própria pesquisa, ao mesmo tempo em que indica outras possibilidades analíticas, dentre as quais a que se propôs esta pesquisa. Munido de um forte apelo a uma linguagem científica, os princípios de economia política que nortearam o pensamento de Silva Lisboa estão inseridos numa visão de mundo composta por uma diversidade de elementos, provenientes de culturas igualmente diversas, que ali convergiam para formar um pensamento conservador, em defesa dos interesses de um Estado monárquico e de uma pequena parcela daquela sociedade, temerosa frente a qualquer possibilidade de mudança significativa na ordem social e econômica, então vigente.

Como destaca Tereza Cristina Kirschner, Silva Lisboa abordou em sua obra questões que vão além do que poderia ser relacionado a problemas acerca da economia. Inserido na virada do século XVIII para o século XIX, o autor era expressão de um típico "homem de letras", tendo produzido textos voltados a uma diversidade temática que passava também pela jurisprudência, história, direito mercantil, política e religião. Diante disso, a historiadora tece o seguinte comentário, sugestivo em relação aos intentos do trabalho aqui proposto: “... Naqueles tempos, as fronteiras do conhecimento não eram tão bem definidas como hoje; esses diversos campos do saber, inclusive a nascente economia política, constituíam ramos da filosofia moral" (KIRSCHNER, 2009, p. 12). Pois bem, é com este olhar que esta pesquisa pretende tomar como objeto os textos de Silva Lisboa; como uma obra de pensamento que comporta várias culturas, formada por um leque

Force e Richard Popkin, referenciados de modo completo na bibliografia. Outros textos, embora de ordem mais introdutória, ainda que interessados na mesma aproximação podem ser encontrados em meio à coletânea organizada por Bernard Cohen e Richard Westfall, sob título Newton: textos, antecedentes, comentários. O terceiro capítulo, intitulado A concepção mecanicista de natureza, a fechar minha própria dissertação de mestrado Ciência moderna e newtonianismo no projeto pedagógico de Luís António Verney, se propôs a apresentar aspectos dessa mesma aproximação na obra de Isaac Newton, que por sua vez interessou ao português Luís António Verney, cuja obra era objeto de análise naquele momento. 
diversificado de problemas, e na qual pretende-se identificar e analisar em que ela é tributária da filosofia natural, no que diz respeito aos conceitos e métodos utilizados por seu autor.

Dotada de tal postura investigativa, Kirschner debruçou-se sobre a obra de Silva Lisboa e organizou os resultados reconstituindo de modo analítico os percursos do autor a partir de sua ida a Coimbra, para realizar a formação universitária em um ambiente que já expressava o espírito da reforma promovida por Pombal. Uma vez retornado à colônia, Kirschner destaca e analisa os principais passos da carreira de Silva Lisboa na administração do império luso-brasileiro, chegando até a atuação de Cairu no cenário político do Brasil, já independente. A pesquisadora destaca a aproximação de Silva Lisboa junto a temáticas da filosofia natural, bem como a ligação do autor à Academia Real das Ciência de Lisboa; aponta também o viés prático com que os saberes ilustrados deveriam servir à colônia e ao império, assim como a decepção de Silva Lisboa, aliás comum entre outros autores contemporâneos a ele, diante de uma cultura colonial que ele julgava ser "rústica" e "iletrada". Também podemos encontrar no trabalho de Kirschner sobre a obra e a atuação de Silva Lisboa, observações bastante pontuais a respeito de um espírito cientificista presente na administração do império português, que sob influência das ideias ilustradas buscava promover uma dada racionalização da produção colonial, tema já tomado como objeto de estudos anteriores (cf. KIRSCHNER, 2009, p. 57 - 67).

Ao apresentar e tecer comentários a respeito de Estudos do Bem Comum, embora de modo sucinto e sem profundas análises, Kirschner destaca parte da problemática a que esta pesquisa pretendeu voltar-se, aliás toca exatamente o problema sobre o qual estiveram debruçadas as atenções da presente análise. A pesquisadora nota que Silva Lisboa, assim como Adam Smith, tomava como pressuposto que no universo existia uma ordem harmoniosa, criada pelo Autor da Natureza e regida por leis. Nota também que Silva Lisboa, a exemplo de seus mestres em economia política, tinha por pressuposto que mesmo a ordem social estava relacionada aos desígnios da Inteligência Infinita (cf. KIRSCHNER, 2009, p. 193). São justamente esses aspectos de podem elucidar questões acerca da visão geral de mundo compartilhada por Silva Lisboa, buscando compreender o modo como se relacionam os elementos que compunham sua obra de pensamento, construída também a partir de elementos encontrados na filosofia natural.

Assim, mais rico em informação do que em análise, o trabalho de Tereza Cristina Kirschner segue apresentando ao leitor farto levantamento a respeito da trajetória 
de Silva Lisboa, em meio a que uma diversidade temática se faz presente, possibilitando saltar aos olhos desta pesquisa, de interesse definido, muitas das questões sugeridas nos parágrafos anteriores. A riqueza temática que ali nos é informada uma vez mais sinaliza a potencialidade do trabalho que está sendo aqui sugerido, bem como possibilita colher informações iniciais acerca dos escritos de Silva Lisboa e dos problemas que esse autor julgou ser pertinente abordar, colaborando para previamente selecionar e orientar a leitura das fontes primárias.

$\mathrm{Na}$ segunda parte do trabalho a que estamos nos detendo neste momento, intitulada Ideias, Kirschner dedica um primeiro subtítulo denominado José da Silva Lisboa e a modernidade portuguesa, onde propõe o exame das ideias do autor no "contexto intelectual da época", a fim de "verificar os fundamentos filosóficos das ideias do ilustrado luso-brasileiro" (cf. KIRSCNER, 2009, p. 289). No entanto, o que encontramos é uma espécie de balanço historiográfico em torno do conceito Iluminismo, estendendo suas consultas até às interpretações provenientes da academia portuguesa; inclusive considerando trabalhos de intelectuais contemporâneos, como Pedro Calafate, ou mesmo intelectuais expressivos de outrora, a exemplo de Hernâni Cidade e Sebastião da Silva Dias. No entanto, praticamente desaparece da análise o próprio objeto de sua pesquisa, ou seja, Silva Lisboa e sua obra.

Mais adiante, nota-se ser muito pouco aproveitada uma promissora possibilidade para a exploração do problema anunciado: a análise dos fundamentos filosóficos em relação ao contexto intelectual em que a obra foi produzida. Kirschner volta a explorar o diálogo intelectual entre Silva Lisboa e os filósofos escoceses, destaca Adam Smith e David Hume, e aponta em ambos a ideia de que os fundamentos da moral não residiam na Revelação Divina; pretendendo estarem apoiados em base empírica, seriam então os fatos da chamada natureza humana os referencias para a filosofia moral pensada pelos notórios escoceses. A autora nota sabiamente que, apesar desses aspectos, Silva Lisboa, católico convicto, conseguia alguma aproximação junto ao trabalho desses pensadores, o que nem de longe ocorria em relação a trabalhos como os de Rousseau, Mably e Condorcet, por exemplo, os quais Silva Lisboa repelia, por acreditar que em tais filósofos residia a disseminação do flagelo revolucionário (cf. KIRSCHNER, 2009, p. 304).

Já encerrado esses primeiros e breves comentários a respeito da pesquisa de Tereza Kirschner, reiterando, muito informativa, nota-se mais uma vez que é possível 
encontrar na obra de Silva Lisboa a presença de aspectos cientificistas, oriundos da filosofia natural de seu tempo. Abaixo, uma citação retirada da pesquisa de Kirschner, a partir da qual isolaremos termos que esta pesquisa pretende tratar como conceitos ou mesmo problemas históricos, a serem analisados pela ótica da História Intelectual:

José da Silva Lisboa conhecia bem esses filósofos. Leu-os a partir da sua visão de mundo católica e soube apreciar aspectos dessa filosofia moral, mesmo discordando do ceticismo de Hume e do deísmo de alguns dos filósofos escoceses, evidência das estratégias e alianças que permearam os debates entre protestantes, católicos e deístas na época. A sociabilidade natural do homem, a uniformidade da natureza humana, o providencialismo, a valorização das virtudes e da dedicação ao bem comum, a crença nos limites da razão humana e nos benefícios da civilização eram temas centrais do iluminismo escocês compartilhados por Silva Lisboa (KIRSCHNER, 2009, p. 307).

O grifos, realizados no momento desta citação, destacam possibilidades analíticas a serem exploradas de modo a ampliar a compreensão do que também encontrase mencionado acima, a visão de mundo de Silva Lisboa, como já notado, composta a partir de uma formação cultural muito diversificada; formação esta que aos leitores contemporâneos aos nossos dias parece pertencer a esferas distintas do saber, quando não opostas, mas que, uma vez analisadas em relação ao contexto intelectual em que foram produzidas e assimiladas, passam a compor uma cosmologia cujo raciocínio lógico e seu encadeamento ainda possuem como demanda análises e compreensões de maior profundidade conceitual.

Embora tenha sido publicada cerca de cinco anos antes do trabalho de Tereza Kirschner, a pesquisa de Pedro Meira Monteiro também precisa ser considerada neste resumido balanço historiográfico, voltado aos trabalhos acadêmicos que tomaram Silva Lisboa e sua obra como objeto de interesse. Cotejando os trabalhos do Duque de la Rochefoucauld e do Visconde de Cairu, Meira Monteiro apresenta ao leitor uma rica análise, que poderia ser tomada como um trabalho em história intelectual. O pesquisador assinala que o primeiro esteve interessado em "desvendar uma mecânica das paixões e dos humores capaz de explicar o humano, reduzido, no diagnóstico moralista, quase a uma máquina”, enquanto o segundo tinha por intento oferecer à mocidade brasileira uma espécie de catecismo moral, no qual boas ações foram apresentadas em contrapartida àquelas voltadas à corrupção do espírito da juventude, sobretudo as que comportassem potencial revolucionário. Destaca Meira Monteiro que em Constituição moral e deveres do cidadão, publicada no Rio de Janeiro entre 1824 e 1825, Silva Lisboa pautou-se "pela 
crença nos valores cristãos, em tudo opostos, na visão de Cairu, à 'moral mundana' que la Rochefoucauld desenhava em suas máximas" (MONTEIRO, 2004, p. 24).

De modo muito inteligente e promissor, Meira Monteiro toma para análise obras desses dois autores, destaca suas respectivas inserções em ambientes e contextos muito diferentes, mas admite como pressuposto que é possível identificar e estabelecer cruzamento entre elas, para então investigar um diálogo entre dois tempos, compreender a recepção das máximas de la Rochefoucauld por Silva Lisboa, o que a este último a obra do primeiro poderia causar de admiração ou repulsa. Não podemos deixar de destacar aqui uma consideração recorrente no trabalho de Meira Monteiro e de grande interesse para esta pesquisa. Trata-se da consideração que faz o pesquisador sobre o caráter nomológico que muitos autores atribuíam às ciências sociais, com especial atenção à economia política e à sociologia, caráter compartilhado por seus próprios fundadores:

... a vontade de regulação, ou de ordenação, que preside as inquirições sobre o organismo social, levando um investigador como Cairu a reverenciar uma Ordem que, em seu discurso, emana ainda do Criador, mas cuja transcendência, no plano científico, apaga-se progressivamente, fazendo-nos esquecer, nos dias de hoje, que o reencontro da lógica social ou econômica pode ser, no fundo e na raiz, a eterna busca do poder ordenador do logos (MONTEIRO, 2004, p. 29).

Pois é justamente esse logos o objeto de estudo a que se prestou esta pesquisa, com especial atenção aos elementos da filosofia natural que nele operam. Atento a uma abordagem da história intelectual, Meira Monteiro aponta possibilidades analíticas a que a obra de Silva Lisboa pode muito bem ser submetida, segundo um interesse que reside na recepção, apropriação e uso de ideias e conceitos apreendidos junto a obras que podem estar em diálogo através do tempo. Meira Monteiro destaca que, segundo a visão de mundo compartilhada por Silva Lisboa, havia um processo de substituição da chamada ordem Providencial pela então chamada ordem econômica:

... a partir de seu catecismo, a substituição progressiva da ordem Providencial pela simples ordem econômica, não menos providencial que aquela, é verdade, embora a razão ordenadora divina se deixe substituir pela razão ordenadora da natureza, a qual terá o filósofo por exegeta. É ainda o logos, em todo o caso, que interessará ao moralista-economista (MONTEIRO, 2004, p. 32).

Por estar dotada igualmente de elementos tidos como transcendentes, a compreensão sobre a ordem econômica exige uma aproximação junto à filosofia natural, 
pois sua presença é explícita e exerceu importância fundamental na coerência que Silva Lisboa procurou imprimir em seu raciocínio lógico. Sua obra demanda ser compreendida também a partir desse viés analítico. Sem compartilhar com a visão do bom selvagem, tão encantadora dos românticos, Silva Lisboa admite que natureza poderia ser mestra da ação. Afirma Meira Monteiro que o retrato humano almejado por Silva Lisboa é o do homem civilizado, fruto dos esforços empregados em um catecismo moral, para o qual a natureza é mestra da ação, na medida em que nas leis naturais encontra-se a sabedoria do Criador e a partir das quais se deve estabelecer as regras sociais, os direitos e deveres do cidadão (cf. MONTEIRO, 2004, p. 66).

A partir deste muito breve e incompleto balanço historiográfico a respeito dos trabalhos acerca de Silva Lisboa e sua obra, é possível observar o quanto variaram as abordagens em relação aos problemas formulados e projetados sobre um mesmo objeto de pesquisa. Primeiramente tido como um intelectual à disposição do Império luso-brasileiro, cujo trabalho por um lado o colocou entre os formadores da nação, mas por outro o fez alvo de duras críticas provenientes da ferocidade de adversários políticos, Silva Lisboa e sua obra continuaram objeto de análise e interpretação de variada ordem de interesse no decorrer da história. Ora como economista, outrora político ou moralista, além de autor de textos voltados à imprensa, Silva Lisboa foi tomado como pensador de considerável envergadura por intelectuais como Alceu Amoroso Lima e Hélio Vianna, por exemplo.

Também submetido a duras críticas formuladas em meados do século vinte, Silva Lisboa e sua obra não foram poupados por outros intelectuais, de reconhecido mérito. Para o literato Antônio Cândido, foi um "palaciano na adulação"; ou ainda aquele de se prestou a "genuflexões constantes diante do poder", segundo o olhar crítico de Sérgio Buarque de Holanda. No entanto, em décadas mais recentes, ainda que pesadas críticas não tenham sido poupadas, novas interpretações surgiram em cena, ampliando o leque de abordagens com um viés mais positivo e que ainda demanda ser levado adiante. Mesmo que criticado por Fernando Novais e Jobson Arruda, que de modo acertado notam na obra e na atuação de Silva Lisboa um trabalho de construção ideológica, voltado à defesa da monarquia e dos interesses de uma elite fundiária brasileira, recém surgida em 1822, também podemos encontrar ali um apelo direcionado a uma nova postura intelectual a ser projetada sobre Silva Lisboa e sua obra. Notam Novaes e Arruda, no artigo intitulado 
Prometeus e Atlantes na forja da nação ${ }^{49}$, que há muito se faz necessária uma "relativização amenizadora", capaz de submeter autor e obra a uma leitura e análise, como já dito, mais positiva.

Justamente esta positividade que se pretende projetar às leituras e análises a serem efetuadas por esta pesquisa, postura que já podemos notar em pesquisas que se colocam a rever conclusões um tanto dicotômicas, a exemplo da que chegou Celso Furtado ao comparar Silva Lisboa e Hamilton. Enquanto o segundo seria um pensador e político obcecado pela industrialização, conclui Celso Furtado ser o primeiro um típico partidário de uma dada leitura do liberalismo, que toma tal escola de pensamento como aquela defensora da postura de não interferência, submetida ao tradicional e quase sempre pouco elucidativo “deixar fazer, deixai passar, deixai vender”. Um novo debruçar sobre o trabalho de Silva Lisboa vem somando novas conclusões diante das quais tal autor por vezes também defendeu a interferência do Estado nas diretrizes econômicas, em resposta a suas preocupações com o desenvolvimento industrial no Brasil ${ }^{50}$.

Por sua vez, esta pesquisa tem por objeto de interesse, por problema histórico a ser projetado sobre a obra de Silva Lisboa, a importância de elementos provenientes ou ainda de estreita ligação com a filosofia natural, os quais estiveram a operar em sua cosmovisão, no modo geral com que esse autor buscou compreender o mundo em que viveu e agiu. Ainda que de modo muito breve, o aqui já mencionado trabalho de Dea Fenelon destaca a erudição de Cairu, e mesmo a consciência que possuía este autor sobre as especificidades regionais do Brasil; a mesma autora, ao lamentar uma certa carência de Silva Lisboa a respeito de uma visão pragmática sobre o próprio desenvolvimento do sistema capitalista, não deixa de bem notar o apego de Silva Lisboa a conceitos como o de ordem natural, a famigerada mão invisível, a ideia de harmônico desenvolvimento, entre outras temáticas (cf. FENELON, 1973, p. 165). Tais comentários, ainda que sem

${ }^{49} \mathrm{O}$ texto citado por Meira Monteiro, cuja autoria é dividida entre os Professores Fernando Novais e Jobson Arruda encontra-se citado na bibliografia e comporta observações acerca das abordagens que a obra de Silva Lisboa já fora objeto de análise, além de apontar a necessidade de outras aproximações, cuja variedade de temas e interesse poderá estender a compreensão a respeito de uma obra de pensamento que ainda pode ser promissora à compreensão dos dilemas e projetos voltados à nação brasileira.

${ }^{50}$ A partir das obras Princípios de Economia Política, bem como Observações sobre o comércio franco no Brasil, Gabriela Spaizmann e João Rogério Sanson concluem que é necessário reconhecer que Silva Lisboa "não só se posiciona em defesa da indústria baseado em princípios liberais, como utiliza-se desses princípios para justificar a tentativa de estímulo à industrialização pela legislação". (SPAIZMANN; SANSON, 2005, p. 35). 
aprofundamento, justamente por não ter sido este o problema sugerido pela citada historiadora, mais uma vez serviu aqui como motivador, como indício de que as questões aqui elaboradas poderiam vir a somar novos saberes a respeito da obra intelectual de Silva Lisboa, pois é justamente esse leque conceitual que interessou à esta pesquisa e que não fora analisado na condição de problema central em nenhuma das outras consultadas, sendo a de Pedro Meira Monteiro a que até então parece mais se aproximar desta proposta. 


\section{Capítulo 2}

\section{O pensamento híbrido de José da Silva Lisboa}

Tomando-se em conta a provável apresentação do livro 'Notícia Histórica da Vida e das Obras de José Hayden, por José da Silva Lisboa, impressiona a forma com que introduz esse primeiro livro sobre o tema 'música', publicado no Brasil.

Não se limita a um comentário da biografia do celebrado compositor austríaco Joseph Haydn. Vai além, destaca o seu espírito inventor, compara a Ciência Musical com as teorias da Matemática e da Física. Perpassa suas origens pela poesia e pela história.

José Augusto Bezerra ${ }^{51}$.

Teria deixado de lado as sociedades secretas, ligadas aos círculos da maçonaria localizados em Salvador nas últimas décadas do século dezoito e início do dezenove, para então voltar-se às questões da fé, em defesa de uma determinada moral religiosa, mais coerente com o projeto de nação que tinha em mente e cuja importância deveria preceder os anseios revolucionários, provenientes das ideias iluministas em circulação nas irmandades do período. Essa hipótese diz respeito ao que se entendeu ser uma guinada ideológica na trajetória intelectual de José da Silva Lisboa, posteriormente intitulado Visconde de Cairu, personagem do universo letrado luso-brasileiro nos anos em que se deu a crise do Antigo Regime e os primeiros passos da formação do Estado nacional brasileiro.

Instrumentalizado por conceitos que também são de interesse da história

${ }^{51}$ Cf.: Bezerra, José Augusto/Schwamborn, Ingrid (orgs.): Joseph Haydn na Corte Real do Rio de Janeiro (1816-1822), Fortaleza: Editora UFC, 2010. Trata-se de um ensaio intitulado José da Silva Lisboa - estadista e intelectual, no qual o autor remete a ampla formação intelectual e atuação de Silva Lisboa, com destaque à hipótese de ter sido Silva Lisboa o autor do primeiro livro sobre música publicado no Brasil. 
intelectual, a intenção é apresentar, compreender, apontar os limites e em determinada medida refutar a hipótese mencionada acima, sobretudo no que diz respeito à separação, de certa forma dicotômica, ali sugerida acerca das culturas que perpassam os escritos de Silva Lisboa. A premissa adotada aqui é a de que a trajetória e a formação intelectual desse letrado luso-brasileiro comportava uma ampla diversidade cultural, cujas contradições observadas pelos estudiosos de sua obra muitas vezes não se apresentavam como tal perante o próprio autor, ou mesmo que entendia ele tê-las superado a partir de uma dada cosmologia, segundo conjunturas e intenções históricas muitas vezes passíveis de identificação e análise. Daí a ideia de pensamento híbrido para expressar uma das características do pensamento de Silva Lisboa, fruto de sua ampla e diversificada formação, reunida em um único discurso, a compor uma cosmovisão de lógica interna razoável, passiva de compreensão e análise.

Embora seja intenção tecer uma análise crítica, a hipótese mencionada acima e tomada aqui como ponto de partida é de sustentação muito razoável, pois o autor oferece farta quantidade de dados e igual clareza de exposição, bem como destacada coerência entre a adoção e o emprego de suas opções teórico-metodológicas. De autoria de Pablo Antonio Iglesias Magalhães, sob título Flores Celestes: O livro secreto de José da Silva Lisboa, o visconde de Cairú ${ }^{52}$, o artigo trata de investigar a autoria de um pequeno livro impresso em Lisboa em 1807: Flores celestes colhidas entre os espinhos da sagrada coroa da augusta veneravel e soberana cabeça do divino e immortal rei dos seculos Jesus Christo.

A partir dessa obra, munido de um instrumental teórico encontrado junto ao paradigma da história indiciária, Iglesias Magalhães chegará ao nome de José da Silva Lisboa e, passando das questões sobre autoria àquelas relativas ao conteúdo, relacionará a obra à saída de Silva Lisboa dos círculos da maçonaria, em função de sua fé cristã e sobretudo de suas posições ideológicas frente às ideias revolucionárias em oposição ao Antigo Regime, tais como a Conjuração dos Alfaiates, ocorrida na Bahia em 1798, com a qual a ligação de Silva Lisboa já chegou a ser cogitada:

Se, conforme os indícios, José da Silva Lisboa foi partidário das ideias

\footnotetext{
${ }^{52} \mathrm{O}$ referido artigo encontra-se publicado sob a seguinte citação: Iglesias Magalhães, Pablo Antonio. Flores Celestes: o livro secreto de José da Silva Lisboa, o visconde de Cairú?História (São Paulo) [On-line] 2012, 31 (Enero-Junio) : [Data de consulta: 15 / noviembre / 2013] Disponível em:〈http://redalyc.org/articulo.oa?id=221022956006> ISSN 0101-9074.
} 
ilustradas e tomou parte na Conjuração dos Alfaiates, na maturidade, após 1810, o Visconde de Cairú passou a combater os ideais revolucionários e as sociedades iniciáticas que os propagavam. Tornou-se um devoto católico fervoroso. Entre José da Silva Lisboa e o Visconde de Cairú está o homem que escreveu o Flores Celestes (MAGALHÃES, 2012, p. 26).

A partir de um dos ramalhetes que compõem Flores Celestes, Magalhães também conclui acerca de Silva Lisboa:

...um homem dividido entre a razão e a fé. Essa é uma característica do Visconde de Cairú nos últimos trinta anos de sua vida. O homem que começou sua carreira escrevendo obras sobre direito mercantil e liberalismo econômico terminou-a escrevendo um Catecismo da Doutrina Cristã, em 1832. Segundo é possível inferir do texto, a razão está subentendida como ideias de inspiração iluminista, que levaram o poeta a se afastar de Deus (ou da Igreja), visto que afirma ter estudado "cruezas oucas" e acreditado em "idéas loucas" (MAGALHÃES, 2012, 28).

Sendo assim, teria Silva Lisboa assumido esse mencionado afastamento dos discursos de forte apelo à chamada razão iluminista, o que socialmente significou sua ruptura com a maçonaria, para então aproximar-se de uma dada moral religiosa, que o levaria a dedicar-se a uma espécie de catecismo moral, que entendia ser mais coerente com os projetos que julgava apropriados para o interesse português e posteriormente para a nação brasileira, recém independente.

Sim, essa é uma hipótese bastante coerente e bem inferida a partir da documentação histórica, mas cabe tecer alguns apontamentos, segundo os quais é possível observar que o abandono dos círculos maçônicos não significou o abandono de uma pretensão racionalista. Em seus escritos, mesmo os que hoje são classificados como sendo de cunho moral, Silva Lisboa apelava à razão e preocupa-se em conferir-lhes uma coerência que não deveria estar exclusivamente ligada a preceitos religiosos. É certo que Silva Lisboa identificava os círculos maçônicos à divulgação dos anseios revolucionários que posteriormente de modo enfático viria a reprimir, no entanto, muitas ideias que eram comuns aos círculos maçônicos continuaram sendo compartilhadas por Silva Lisboa, porque entendia ele serem dotadas de uma razoabilidade suficiente, fruto de uma epistemologia que a ele se apresentava como a mais razoável e convincente, por isso adotada e aplicada em suas interpretações acerca do império português e futuramente do Brasil.

Pares dicotômicos a exemplo de fé e razão, religião e ciência, podem esclarecer 
mas também podem ocultar. Período de efervescência como foi o da crise do Antigo Regime requer cuidado e minúcia ao ser analisado; para homens como Silva Lisboa e tantos outros contemporâneos a ele, sequer termos como metrópole e colônia poderiam ser empregados com a mesma eficácia em todas as conjunturas. Muitas vezes preferiram fazer referência ao império, pois em determinadas conjunturas se viram como luso-brasileiros. A retomar as questões mais ligadas à filosofia, é possível sugerir que na obra de pensamento de Silva Lisboa nem sempre operaram de modo dicotômico conceitos como religião e ciência, fé e razão. De certa forma, sua cultura era híbrida sem com isso lhe parecer contraditória. Também não está excluída aqui a possibilidade de que, em função de conjunturas de ordem diversa, ele também forjasse coerências que de fato não as concebia, como em casos ligados à política, por exemplo. Aqui optou-se por não abordar casos que por ventura fossem dessa natureza.

Passa a ser necessário ilustrar e discorrer então acerca dessa hibridez cultural, aqui tomada no sentido de uma cultura que é formada por elementos diferentes, variados, não homogêneos, provenientes de ambientes sociais e correntes de pensamento que igualmente sugerem entre si mais diferenças do que semelhanças. Diretamente ligado ao caso de Silva Lisboa, a filosofia natural no século dezoito apresenta traços dessa hibridez, e nela é possível identificar correntes de pensamento já muitas vezes tomadas como muito distintas, quando não francamente opostas. A referência em filosofia natural no século dezoito foi a filosofia natural de Isaac Newton e o newtonianismo, de um modo mais geral. Embora não evidenciados em muitas pesquisas acerca do tema e sobretudo não comprometedores do conhecimento laico que essa máxima expressão da Revolução Científica comportava, muitos aspectos da filosofia natural de Newton e esse movimento intelectual conhecido como newtonianismo carregava em si elementos dotados de uma certa hibridez. Notável por sua face experimental, pelas análises matematizadas, pelas demonstrações e mesmo pelas previsões de fenômenos naturais, a filosofia natural de Newton, embora capaz de sustentar-se sem apelo a preceitos religiosos e a prévia definição de alguns conceitos a partir da metafísica, continha uma preocupação ligada à fé monoteísta, de raízes judaico-cristãs.

As concepções teológicas de Isaac Newton vêm sendo exploradas por alguns pesquisadores que têm depositado grandes esforços sobre essa temática. Interessados em questões dessa vertente, autores como James Force e Richard Popkin reuniram alguns de seus artigos em uma obra intitulada Essays on the context, nature, and influence of Isaac 
Newton's theology, onde compartilham a tese de que as ideias religiosas ocupam papel central no pensamento de Newton, o qual deve ser estudado de modo mais completo, considerando-o enquanto cientista, teólogo, alquimista, historiador e intérprete da Bíblia. Segundo os autores, tal postura diante da obra de pensamento de Newton permite compreender melhor toda a complexidade que caracteriza a passagem da fé religiosa, de tradição judaico-cristã, para a chamada Era da Razão, que identificava na filosofia newtoniana uma fonte de inspiração (cf. FORCE; POPKIN, 1990, p. VII - IX).

Um dos artigos da coletânea apontada acima, Some Further Comments on Newton and Maimonides, o autor, Richard Popkin, chama a atenção para o grande interesse de Newton sobre a antiga tradição judaica e o quanto seu pensamento foi influenciado pelos textos do teólogo medieval Moses Maimonides $(1133-1204)^{53}$. Os textos de Maimonides foram de grande interesse para alguns filósofos modernos em decorrência de sua importância teológica ou mesmo por suas descrições da antiga tradição religiosa judaica; o próprio Newton recorreu a eles em seus estudos sobre o Templo de Salomão. Todavia, é no famoso Escólio Geral, localizado no terceiro livro dos Princípios Matemáticos de Filosofia Natural, que Richard Popkin identificou a mais significativa utilização que Newton possa ter feito das ideias judaicas, retiradas da obra de Maimonides. Ali, Newton argumenta a favor da existência de Deus, deixando claro que sua concepção não se tratava de um simples deísmo, mas sim de algo mais próximo à concepção judaica, porque é um argumento fundamentado na ideia de propósito, de um devir manifestado no ininterrupto domínio exercido por Deus no universo (cf. POPKIN, 1990, p. 01 - 06).

Não cabe aqui retomar em toda a sua profundidade tais análises sobre a formação do pensamento newtoniano, cuja maior riqueza parece estar mesmo na atenção com que esses pesquisadores inserem as ideias de Newton em seu devido contexto intelectual, buscando compreendê-las a partir da aproximação entre filosofia e história.

\footnotetext{
${ }^{53}$ Moses Maimonides (1133 - 1204) foi um rabino medieval, autor de grande importância para o pensamento cristão desde o século XIII. Sua obra, The Guide for the Perplexed, trata-se de uma das primeiras tentativas de aproximação entre a filosofia de Aristóteles e o pensamento bíblico, entre ciência grega e fé cristã, que representava um perigo para o mundo cristão e quase uma heresia para o mundo judeu. Já no século XVII, a obra foi publicada em latim e filósofos como Leibniz, Malebranche e Bayle a mencionam. No contexto da Inglaterra moderna, Maimonides foi fonte de informações sobre antigas práticas judaicas e mesmo sobre a exata natureza do Templo de Salomão, com seus objetos, vasos e querubins, que muito interessava aos adeptos do milenarismo, como foi o próprio Newton, e para os quais o Templo representava uma chave para a compreensão do universo, na medida em que foi um microcosmo do projeto elaborado por Deus. Na biblioteca de Newton, que está em Trinity College, Cambridge, há cinco trabalhos de Maimonides (cf. FORCE; POPKIN, 1990, p. 02 - 05).
} 
Conforme as ideias de Newton foram sendo divulgadas e debatidas pela Europa iluminista, essa face de sua obra, que talvez o próprio Newton não tenha tido a intenção de enfatizá-la em seus textos sobre filosofia natural, permitiu que determinados leitores nela identificassem significativas diferenças em relação às formas mais comuns do deísmo, pois ali estava concebido um universo não apenas criado, mas ainda governado por Deus, conforme encontramos no Escólio Geral. Embora o funcionamento de sua mecânica racional, de sua física matemática, prescindisse de qualquer explicação de cunho teológico, o autor dos Principia também preocupa-se em tecer colocações como a que se segue abaixo:

... Este sistema belíssimo do sol, planetas e comentas só pode ter surgido do conselho e domínio de um Ser inteligente e poderoso. ...

Este Ser governa todas as coisas, não como a alma do mundo, mas como Senhor sobre tudo. E devido a seu domínio costuma ser chamado Senhor Deus, ou Amo Universal. Pois Deus é uma palavra relativa que se refere a servos ... O Deus Supremo é um Ser eterno, infinito, absolutamente perfeito. Mas não se pode dizer que um ser assim sem domínio, embora perfeito, seja o Senhor Deus. ... Só o conhecemos por suas invenções mais sábias e excelentes das coisas e pelas causas finais; o admiramos por suas perfeições, mas o reverenciamos e adoramos devido ao seu domínio. Pois o adoramos como seus servos; e um deus sem domínio, providência e causas finais nada é a não ser Destino e Natureza (NEWTON, 2008, p. $328-330)$.

Muitos dos newtonianos certamente não conheciam, como hoje se conhece, o variado leque de preocupações implícitas na filosofia natural de Newton, mas identificavam nela uma orientação que atendia à necessidade de se evitar possíveis contradições entre filosofia natural e fé. A filosofia natural que mais atendia aos anseios racionalistas do pensamento iluminista em geral também era aquela que poderia satisfazer as necessidades de um pensador católico, como está expresso, por exemplo, na obra do português Luís António Verney ${ }^{54}$, mesmo que isso se desse à revelia do próprio Newton,

\footnotetext{
${ }^{54}$ Luís António Verney foi um padre português, ligado aos oratorianos e radicado na Itália, de onde exerceu oposição exaltada à ação pedagógica da Cia. de Jesus. Sua obra de maior divulgação foi o Verdadeiro Método de Estudar, publicada em 1746, e cuja repercussão e polêmica desencadeada assegurou a Verney um lugar entre os principais nomes do iluminismo ibérico. Trata-se de uma obra de fôlego, publicada em cinco volumes, que aborda temas diversos, passando pela ética, física, lógica, medicina, teologia, moral, jurisprudência, entre outros. Escrita em forma de cartas dirigidas formalmente ao Reverendo Padre da Universidade de Coimbra, utiliza de uma linguagem simples, de compreensão acessível a um público não tão erudito, ao qual parece de fato se dirigir em tom divulgador. Na carta de mais de uma centena páginas dirigida exclusivamente aos estudos da física, Verney divulga o método newtoniano e recomenda sua adoção nos sistemas de ensino português, saindo em defesa dos modernos e em franca oposição à escolástica. Além do Verdadeiro Método, Verney foi autor de manuais de ensino, dentre os quais encontra-se um extenso manual para os estudo da física, De Re Physica, onde demonstra ter conhecido a
} 
como assim foi.

A partir dessa perspectiva, a filosofia natural que foi referência maior do Iluminismo, bem como seu desdobramento enquanto uma voga intelectual, o newtonianismo, assume então uma complexidade que supera a possibilidade de análises muito esquemáticas. José da Silva Lisboa era admirador da obra newtoniana e adotava conceitos que nela encontrou, deslocando-os da filosofia natural para abordagens de ordem diversa. O newtonianismo, enquanto um modelo geral da ciência e sua respectiva influência sobre a cultura iluminista já foi apresentado e analisado por um considerável número de trabalhos ${ }^{55}$, dentre os quais podemos destacar a obra de Ernest Cassier, que o tratou de modo bastante suficiente e que qualquer pesquisa razoável acerca do tema pode tomar como leitura necessária:

... a filosofia do século XVIII está, em todas as suas partes, vinculada ao exemplo privilegiado, ao paradigma metodológico da física newtoniana; mas logo sua aplicação foi generalizada ... o instrumento necessário e indispensável para todo o conhecimento em geral (CASSIRER, 1994, p. $30)$.

O historiador Thomas Hankins, em Science and the Enlightenment, afirma que o pensamento iluminista não pode ser tomado como um conjunto estático de convicções, mas sim como um modo de pensar, cuja mais importante característica reside no fato de que foi capaz de proporcionar abordagens críticas e ações construtivas, fornecendo ao homem condições de aprimorar o conhecimento e superar os equívocos do passado. Dessa forma, a filosofia natural caiu como uma luva aos anseios da época e, de um modo geral, os iluministas julgavam que os filósofos naturais, sobretudo por seus métodos, eram aqueles que melhor expressavam a ideia de progresso e acúmulo do saber. A filosofia natural foi tomada pelos iluministas como o ponto de partida mais razoável para a

obra de Newton, sobretudo através de seus principais intérpretes e no qual compartilha de modo explícito as concepções teológicas contidas na visão de mundo mecanicista do filósofo inglês.

55 Dentre a farta bibliografia a respeito do newtonianismo é válido destacar: COHEN (1983); WESTIFALL (1983); COHEN; WESTFALL (2002), HANKINS (1985). A primeira obra trata-se do mais importante trabalho sobre a formação e recepção inicial da física de Newton; a segunda está voltada à biografia de Isaac Newton, abordando em centenas de páginas desde a difícil infância de um menino privado do contato com os pais até as inquietações teológicas, passando necessariamente pelos aspectos científicos de sua obra, oferecendo assim uma cuidadosa interpretação sobre os dilemas e as acirradas disputas que acompanharam o desenvolvimento da filosofia natural de Newton. A terceira citação é uma coletânea de textos do próprio Newton, acompanhada de artigos escritos por reconhecidos estudiosos da ciência e da filosofia moderna, organizada por Bernard Cohen e Richard Westfall. A última está voltada sobretudo à relação entre newtonianismo e o pensamento ilustrado. 
construção de novos saberes.

Num contexto sob tal orientação ideológica, muitos filósofos naturais passaram a assumir o status de verdadeiras notoriedades, sendo que no decorrer do século XVIII Newton tornou-se a maior delas, visto como uma mente brilhante, capaz de resolver a questão dos movimentos planetários, submetendo-os à mesma explicação que respondia pelos movimentos terrestres. Ainda Hankins: "o percurso mais óbvio para o avanço da filosofia natural seria concluir o programa de investigação de Newton, utilizando os seus métodos. A ciência do Iluminismo seria então 'newtoniana' e a sua filosofia o 'newtonianismo'"' (HANKINS, 1987, p. 09).

O impacto da síntese newtoniana sobre a cultura europeia, segundo uma passagem um tanto sugestiva de Paolo Casini, se deu a partir das diversas formas com que o newtonianismo se manifestou, ora afastando-se, outrora aproximando-se das ideias do próprio Newton, mas sempre ampliando o leque temático dessas apropriações:

... no plano físico-astronômico, ofereceu uma nova síntese radicalmente oposta à persistente influência cartesiana; no plano epistemológico, ensinou a libertar-se da metafísica substancialista; na química e na medicina, foi constantemente um ponto de referência, ainda que polêmico. Havia também, como se sabe, o newtonianismo frívolo dos literatos e dos poetas que narraram em versos os fenômenos da óptica e a teoria da atração. E, finalmente, o newtonianismo dos apologistas religiosos, como a abbé Pluche, que seguiram a nova moda atualizando as velhas demonstrações da existência de Deus, à imitação dos apologistas newtonianos ingleses (CASINI, 1995, p. 107).

O newtonianismo, enquanto fenômeno da história intelectual, pode ser tomado como peça fundamental do que podemos chamar de uma ciência iluminista, um fenômeno decorrente da compreensão e divulgação, sobretudo do método experimental e das leis gerais da natureza formuladas por Newton, para além daqueles círculos formados por especialistas em ciência física e matemática, no sentido estrito. Portugal não esteve fora desse efervescente e intrincado contexto de ideias marcado pela influência do newtonianismo, face científica do ideário iluminista. Já sob o reinado de D. João V, segundo estudos contemporâneos como os conduzidos pelo português Pedro Calafate, Portugal começa a se abrir para o movimento das Luzes, criando condições básicas para aquilo que culminaria na reforma da Universidade de Coimbra, em 1772, ainda no 
contexto das reformas promovidas pelo Marquês de Pombal ${ }^{56}$.

José da Silva Lisboa esteve inserido justamente nesse contexto da reforma universitária promovida durante a administração pombalina, daí seu apelo à filosofia natural e ao newtonianismo que era típico dos iluministas, embora seja esse mesmo autor a refutar o que a mesma Ilustração carregava de anseios revolucionários, que almejavam profundas transformações em relação às estruturas do Antigo Regime. As vozes modernas não soam em uníssono aos ouvidos de Silva Lisboa. Rousseau é uma dissonância que precisa ser evitada, o irlandês antirrevolucionário Edmund Burke tende mais às moderações e os economistas ingleses possuem as análises mais razoáveis para se alcançar o que chamava de Bem Comum até mesmo em uma nação tão díspar, profundamente marcada pelo escravismo. Em todas essas escolhas, Silva Lisboa não separava os atos de pensamento a operar segundo a razão iluminista daqueles a operar segundo os preceitos religiosos que compartilhava. Esta é a hibridez difícil de ser compreendida, porque o tempo histórico que separa o autor em questão de seus estudiosos da contemporaneidade está carregado de um saber que, ao longo de séculos, consagrou-se também por sua divisão em áreas específicas, quando não opostas ou não condizentes. Hoje admite-se que elas se misturavam, a compor um só discurso com mais facilidade do que fora estimado.

Conforme já apresentado, originário da cidade de Salvador, Silva Lisboa atravessou o Atlântico para frequentar a Universidade de Coimbra entre 1774 e 1779, chegando a ser nomeado professor substituto de grego e hebraico no Colégio das Artes de Coimbra, no ano de 1778. De volta à Bahia, exerceu o magistério ao lecionar filosofia por dezenove anos, retornando a Portugal em 1797, para publicar obras sobre direito mercantil e economia política. Mais uma vez na colônia, chegou a ser deputado e secretário da Mesa

56 Em meio à historiografia portuguesa contemporânea podem ser encontrados inúmeros estudos voltados a tal interesse: CALAFATE (2001); CALAFATE (1994). DOMINGUES (1994); ROVIRA (1958); DIAS (2006); ANDRADE (1946). Sob a direção de Pedro Calafate, nota-se no terceiro volume da "História do Pensamento Filosófico Português", denominado "As Luzes", a realização de um trabalho bastante elucidativo sobre o tema. Relaciona o período do final do reinado de D. João V até o consulado pombalino com as especificidades do pensamento português e sua aproximação junto ao pensamento italiano, devido à forte tradição católica; nota-se ali o ecletismo se aproximando do despotismo e se colocando contra o materialismo, o espírito de sistema cartesiano e o deísmo, típicos do período da ilustração. O período da Reforma Pedagógica de Portugal esteve marcando pelo esforço em aproximar o pensamento português às ideias mais progressistas do Iluminismo. Do mesmo autor, temos A idéia de natureza no século XVIII em Portugal. Ainda sobre a presença do pensamento ilustrado em meio à cultura letrada portuguesa, há o trabalho de Contente Domingues, Ilustração e Catolicismo. Teodoro de Almeida e também o trabalho de Rovira, que estende-se até os letrados da América espanhola. Anterior a este último, encontra-se a importante pesquisa de Silva Dias: DIAS, J. S. da Silva. Portugal e a cultura européia (séculos XVI e XVIII). 
de Inspeção da Bahia, juntou-se ao corpo de funcionários e administradores que acompanharam a família real em sua chegada ao Brasil. Atuaria na administração do império, com esforços dirigidos à organização do comércio; já sob condição de deputado da Real Junta de Comércio, Agricultura, Fábricas e Navegação do Estado do Brasil foi autor de um código para regulamentação específica dessa atividade, que julgava determinante para o progresso da riqueza no Brasil e em todo o império português.

A passagem pela Universidade de Coimbra aproximou Silva Lisboa de todo um cenário intelectual resultante da reforma dos estudos universitários sob orientação do governo do Marquês de Pombal, portanto, um ambiente intelectual já de alguma forma influenciado pelas ideais iluministas, entre as quais esta pesquisa pode destacar filosofia natural, em especial aquela de vertente newtoniana. Naquele ideário o universo de estudantes do qual Silva Lisboa fazia parte encontrou uma matriz de inteligibilidade dos fatos, uma epistemologia que parecia razoável e convincente, um instrumento capaz de proporcionar um entendimento cognitivo dos mais variados aspectos da realidade.

Sob tal influência, mesmo aderindo a um discurso moral, caracterizado por sua intensa religiosidade católica, não abriu mão de análises que fossem resultado da razão iluminista. A partir dos casos apresentados nota-se o fato de que Silva Lisboa sequer concebia com grande preocupação, talvez até com pouca clareza, esses afastamentos entre fé e razão, submetendo a realidade e seus mais variados objetos de interesse a uma mesma cosmologia, formada por diversas culturas de diversificada origem. Se no presente momento depara-se com a necessidade ou mesmo a dificuldade de explicar a característica híbrida de seu pensamento, ao próprio autor tal diversidade parece prescindir de qualquer esclarecimento. A ele, não havia ali qualquer contradição, quando sim, poderiam ser complementares.

A começar pela relação entre filosofia natural e os estudos acerca do que podemos classificar como sendo os de economia, é necessário destacar que Silva Lisboa foi confesso admirador de Adam Smith, e uma vez capaz de identificar elementos científicos na obra do renomado economista inglês, compartilhava uma dada cosmologia que buscava aplicar às questões luso-brasileiras ligadas à formação histórica, projetos econômicos e políticos, bem como em análises a respeito da formação e organização da sociedade brasileira. A delimitar as atenções sobre Estudos do bem comum e economia política, ali não faltam elementos para identificar no trabalho de Silva Lisboa concepções ligadas à ciência moderna. Dentre os trechos mais sugestivos para ser submetido à tal 
investigação, podemos citar os parágrafos iniciais do segundo capítulo, no qual a existência de uma cosmologia cientificista dá indícios mais do que evidentes:

O Universo criado é um Sistema, organizado de partes, que estão em harmonia entre si, e com o Grande Todo, e é regido por Leis Imutáveis da Ordem Cosmológica, que a Inteligência Eterna determinou, e que invariavelmente, se executam no Mundo Physico. A constância e imutabilidade dessas Leis é o fundamento de todos os nossos conhecimentos. [...]

Como a astronomia inquire as leis que regem as órbitas dos Astros no Sistema Planetário; e a Zoonomia investiga as Leis da vida dos animais, assim também a Economia Política examina as Leis que o Autor da Natureza estabeleceu no Sistema Social, ou Ordem Civil, para a subsistência, multiplicação, e prosperidade dos homens, desenvolvendo eles as suas qualidades sociais, e faculdades do espírito e corpo (LISBOA, 1819, p. 148).

Nesta presente ocasião, de modo a compor e estender a análise anunciada ainda nas páginas introdutórias, foram selecionados alguns dos conceitos da cosmologia adotada por Silva Lisboa, a fim de submetê-los à análise e buscar alguma compreensão a respeito do modo como esse autor se colocava a conhecer os princípios da economia política, sabendo que as ciências naturais estavam presentes em seu horizonte epistemológico, afinal, ele questionava acerca de leis gerais, preocupava-se em compreender uma dada ordem pretensamente invariável, a atuar no mundo físico, quiçá nos sistemas responsáveis pela organização das sociedades.

Silva Lisboa preocupa-se em distinguir a ciência econômica, que chama de Economia Política, a partir de algumas de suas singularidades frente a outras ciências, no entanto, é evidente e muito sugestivo o modo como ele justifica a importância dessa específica área do conhecimento: por tais singularidades, a economia política é a ciência capaz de proporcionar o saber a respeito de uma das partes do que entendia ser um Grande Todo. Sem ela não haveria acesso ao conhecimento sobre essa determinada parte, e menor seria o conhecimento sobre essa totalidade, pois, segundo seu entendimento, as partes e o todo encontravam-se em harmonia. Embora seja pertinente e viável perguntar sobre os pressupostos que levavam o autor a esta concepção de totalidade harmônica do universo, nesta ocasião as atenções foram direcionadas uma outra questão: o que permitia a Silva Lisboa relacionar o saber específico de uma determinada ciência a um universo que ele concebia como um Grande Todo?

Para esboçar algumas respostas foram isolados alguns termos utilizados por Silva Lisboa, visando entendê-los enquanto conceitos através dos quais esse autor, de 
modo coerente, tecia suas explicações sobre a viabilidade epistemológica e a importância da ciência econômica. O primeiro deles pode ser o termo sistemas, que pressupõe um conjunto diverso de elementos, submetidos a uma organização fruto da atividade intelectual, responsável por estabelecer relações lógicas entre esses elementos.

A ideia de sistema é típica do mecanicismo dos modernos, a se tomar pela menção que nomes como Descartes e Newton fizeram do conceito ao elaborar suas respectivas hipóteses de sistema mundo. A obra de Newton era para Silva Lisboa um modelo de explicação, porque ali encontrava-se a mais bem formulada resposta sobre o movimento dos corpos celestes, suas respectivas disposições e a configuração de suas órbitas, de modo a conceber um organizado sistema planetário, cujo movimento dos corpos poderia ser racionalmente compreendido. O principal intento da ciência da economia seria então voltar-se ao que chamava de Sistema Social ou Ordem Civil, para então buscar compreendê-lo racionalmente. Para isso, foi de fundamental importância a adoção de uma cosmologia cientificista, que possibilitasse o conhecimento razoável em diversas áreas do saber, seja na astronomia ou na zoonomia, seja nos sistemas sociais.

O universo criado é um Sistema, harmoniado pelo seu omniscio Architector, composto de vários sistemas parciais do mundo physico e moral: a sociedade civil é um sistema: cada Nação é um sistema parcial do total sistema da sociedade civil: tudo neles é ligado por constantes Leis, ou relações naturais, de que depende a sua ordem, conservação, ou destruição (LISBOA, 1819: 68).

Segundo a visão de mundo compartilhada por Silva Lisboa, é possível refletir sobre o universo enquanto um conjunto de sistemas, cuja harmonia é garantida por outro conceito que é chave em seu esquema de raciocínio: o conceito de leis naturais, as quais são executadas de modo invariável em todo o mundo físico. Como notado a partir das citações anteriores, sobretudo a partir daquela onde são classificadas de Leis Imutáveis da Ordem Cosmológia, as leis naturais devem estar no centro das atenções daquele que se coloca a conhecer, pois trata-se do fundamento de todos os conhecimentos. O conceito de sistema, articulado ao de lei natural, são dois preceitos teóricos cruciais na cosmologia cientificista que é adotada por Silva Lisboa. A presença de leis gerais nos mais diversos sistemas, da astronomia à sociedade civil, garante não somente a possibilidade de um conhecimento razoável nas mais diversas áreas do saber, mas também a visão de que tais sistemas compõem um todo harmonioso que pode ser conhecido pelo homem. 
Inquirir e achar essas Leis e relações é o objeto de todas as Ciências Humanas: a certeza da verdade dos nossos conhecimentos a esse respeito é a que estabelece os Princípios e Sistemas, que são o fundamento da reta Legislação e Administração dos Estados, e prosperidade dos indivíduos...(LISBOA, 1819, p. 69).

Assim como Adam Smith, que talvez tenha sido o seu maior mentor intelectual no que diz respeito à economia política ${ }^{57}$, Silva Lisboa concebia a possibilidade de adotar alguns conceitos e terminologia da filosofia natural nos estudos acerca das sociedades. Mais que fonte de inspiração, em algumas passagens o autor faz explícita referência à física moderna com a finalidade de justificar a importância e a viabilidade da ciência econômica, visto que ela pode gerar um tipo de saber que caminha no sentido daqueles trabalhos, sobretudo no sentido da física newtoniana, como é possível depreender a partir do seguinte trecho: "Economia Política é verdadeiramente Physica Social, e Dinâmica Civil, fundando-se a relativa civilização, e opulência dos países, no seu comparativo cálculo de emprego das forças do espírito e corpo na Indústria Nacional" (LISBOA, 1819: Prefácio).

A sociedade é para Silva Lisboa um objeto cuja análise deve ser encaminhada em moldes semelhantes ao mecanicismo dos modernos, sendo assim, entende que a ciência econômica é a física social, e abusa da apropriação terminológica ao estender a classificação também chamando-a de dinâmica civil. A economia política seria então a ciência capaz de proporcionar tal saber, como está dito no trecho abaixo, no qual tece elogios à obra de Adam Smith, e no qual estão presentes elementos típicos de uma postura newtoniana:

É indisputável, que Smith se pode intitular o Proto-economista da Europa, por ser o primeiro que elevou a Economia Política á Ciência regular, fundando a sua teoria em Princípios, estabelecendo Teoremas, e deduzindo Corolários, quase com rigor matemático, e método analítico; com muitas ideias originais, judiciosa observação de fatos experimentais das Nações civilizadas, e perspicaz critério dos Sistemas estabelecidos; propondo, depois da discussão deles, o seu que diz obvio e simples Sistema da Liberdade Natural... (LISBOA, 1819, p. 71).

57 No quinto capítulo de Estudos do Bem-Comum, após citar e tecer comentários sobre o que autores como Francis Bacon, David Hume, John Locke afirmaram sobre a riqueza das nações, passando pelo próprio Newton, o qual elogia pelas melhorias implantadas na Casa da Moeda de Londres, Silva Lisboa chega ao nome de Adam Smith, em cuja obra identifica a primazia em elevar a economia política à condição de sciencia regular (cf. LISBOA, 1819: 60 - 71). Ver também a obra de Tereza Cristina Kirschner, segunda parte da obra José da Silva Lisboa, Visconde da Cairu: Itinerário de um ilustrado luso-brasileiro (cf. KIRSCNER, 2009: 302 - 317). 
A historiografia sobre a obra de Silva Lisboa por diversas vezes sinalizou a possibilidade de se perguntar acerca das relações históricas entre a cosmologia adotada pelo autor e sua respectiva obra de pensamento. Como também afirmado outrora, de modo recorrente pesquisadores já indicaram a necessidade de se estender os estudos sobre a obra de pensamento de Silva Lisboa a tal direção temática, afinal, foi autor de textos que passam por ampla diversidade de questionamento, tratando de filosofia, história, jurisprudência, direito mercantil, política e religião, para finalizar seus escritos preocupado com questões ligadas ao problema da moral. Visto deste modo, os elementos a partir dos quais Silva Lisboa prendia conferir razoabilidade e lógica interna à sua obra, de diversificada formação cultural, torna-se promissor objeto de pesquisa a ser compreendido pela história das ideias.

Com análises tecidas pelo pesquisador Pedro Meira Monteiro tem início o segundo estudo de caso realizado para e ressaltar essa face híbrida da cosmovisão de Silva Lisboa. Embora sua pesquisa possa causar estranhamento ao modo de interesse que é mais típico ao historiador, o trabalho de Meira Monteiro é um rico ensaio literário cotejando as ideias do Duque de la Rochefoucauld e de Silva Lisboa. Meira Monteiro volta-se ao catecismo moral que Silva Lisboa oferece à mocidade brasileira, uma espécie de ordenação que ele acreditava ser radicalmente oposta à moral mundana, identificada nas máximas de Rochefoucauld. A partir de tal oposição, Meira Monteiro retira dos escritos de Silva Lisboa um sentido reformador, muito menos pessimista do que poderia conceber Rochefoucauld, mas sim crédulo nas possibilidades humanas, simpático ao sentido positivo que extrai dos fundadores da economia política, de origem inglesa. Silva Lisboa identificava nesses ingleses um dado instrumento teórico que lhe parecia sobretudo muito mais conveniente, para não dizer promissor, ao contexto histórico no qual esteve inserido (cf. MONTEIRO, 2004).

Umas das teses centrais do trabalho de Meira Monteiro é a de que em seu catecismo moral, Silva Lisboa demonstra:

... a substituição progressiva da ordem Providencial pela simples ordem econômica, não menos providencial que aquela, é verdade, embora a razão ordenadora divina se deixe substituir pela razão ordenadora da natureza, a qual terá o filósofo por exegeta. É ainda o logos, em todo o caso, que interessará ao moralista-economista (MONTEIRO, 2004, p. $32)$. 
Meira Monteiro ainda aponta em Constituição moral e deveres do cidadão, obra de Silva Lisboa publicada em 1825, respostas do autor baiano às investidas da maçonaria contra a Igreja; no entanto identifica nessas mesmas respostas apelos que não são provenientes, de modo único e exclusivo, de uma determinada teologia ou de aspectos puramente religiosos. Silva Lisboa tem os interesses marcados pela ideia de fundação da nação brasileira, e a pensa sob dois aspectos: a formação de um país nascente, uma pátria livre, portanto preocupações políticas; mas tal fundação deveria se dar segundo as bases morais que necessariamente iriam operar junto a essa mesma nação. $\mathrm{O}$ edifício jurídico muitas vezes está ali sugerido segundo balizas morais. Sendo assim, ainda restaria identificar em Constituição moral e deveres do cidadão outras referências, e eis que elas surgem de sua atenção às obras dos moralistas do século dezoito, segundo uma leitura criteriosa e também seletiva: David Hume e mesmo Adam Smith são ali identificados por Meira Monteiro, sem que essa mesma aproximação de Silva Lisboa junto às ideias de tais autores o impedisse de atribuir severas críticas ao deísmo presente nas obras desses pensadores (cf. MONTEIRO, 2004, p. 195 - 197).

Ainda que sem estender apresentação e comentários sobre a minuciosa análise referida aqui nos últimos parágrafos ${ }^{58}$, cabe dar ênfase ao fato de que ela informa sobre a hibridez cultural que é possível extrair da obra de Silva Lisboa. O discurso dos modernos é por ele tomado de modo seletivo e projetado sobre condições sociais e políticas distantes daquelas experimentadas por seus autores europeus, condições que por vezes sequer foram pensadas pelos mesmos com a devida profundidade. Smith ou Hume não tiveram em conta analisar e ponderar acerca de questões ligadas à América portuguesa, mas para Silva Lisboa muitas das ideias sugeridas por essas matrizes do pensamento ilustrado não estariam fora do lugar quando aplicadas a estudos de caso e análises acerca da América portuguesa, daí seu esforço em adaptar conceitos e teorias a partir de uma cosmovisão

58 Silva Lisboa tinha preocupação prioritária em afastar do Brasil o perigo de uma revolução aos moldes da francesa e sobretudo daquela ocorrida nas Antilhas, cuja composição social semelhante à de sua nação fazia redobrar os temores da elite da qual fazia parte. Daí sua veemente crítica à Conjuração dos Alfaiates, bem como à Confederação do Equador; daí sua repulsa a Frei Caneca. O Catecismo moral de que é autor, cuja formação apela tanto a preceitos encontrados nos discursos religiosos quanto na própria razão de cunho iluminista, está voltado a evitar qualquer onda revolucionária e contra o que classificava de uma natureza impulsiva e bárbara, que deveria ser contida e reeducada pela ordem social e moral. Penalves Rocha lembra que, em Estudos do Bem Comum, esteve em jogo interesses reformadores da grande lavoura escravista, evitando riscos maiores sempre lembrados, nas palavras de Silva Lisboa, pelo "hórrido espetáculo da tremenda catástrofe da Rainha das Antilhas, transformada em Madagascar, pela imediata causa da indefinida e tumultuária acumulação de bárbaros etíopes" (cf. ROCHA, 1996, p. 159). 
marcada por uma formação plural a compor um todo tido por ele sem contradições.

A exemplo de outros autores, Silva Lisboa realizou uma determinada aproximação junto ao ideário moderno cuja compreensão somente se faz a contento quando consideradas as conjunturas históricas da recepção e da aplicação dos conceitos aprendidos. A encerrar este segundo momento ilustrativo acerca da complexidade que permeia a formação cultural expressa por Silva Lisboa, vale retomar a análise de Meira Monteiro com uma citação que de fato é longa, mas carregada de sentido e implicações, mesmo para os dias atuais e a questões que nos cercam neste momento:

Reforço a interpretação, por acreditar que o deslocamento de sentidos, de um mundo Providencial rumo às constatações científicas (moralistas), seja fundamental para compreender o corte "sociológico" da empresa de Cairu, interessado em reagir ao desastre revolucionário, crente ainda nas armas divinas, mas absolutamente ciente de que elas, sozinhas, tornavamse insuficientes.

O Primado e a exclusividade da "razão" eram detectados como afronta ao ordenamento civil, não porque o moralista brasileiro simplesmente a julgasse obra demoníaca. O Pacto maldito surgia apenas quando aquela estrutura social que Cairu aprendeu a valorizar e proteger era ameaçada, em nome de uma universalização de direitos inconcebível para um homem, como ele, crente na virtude do velho edifício político, com seus altos postos e sua cabeça intangível, e na natureza superior dos espíritos capazes de ocupá-los.

As crenças liberais, nesta obra de José da Silva Lisboa (Constituição Moral), casam-se a uma ordem social inabalável, sugerindo um desconcerto que, convenhamos, não é exclusivo dos séculos passados, e talvez nem seja uma característica avantajada entre nós, e bem compassada nas nações europeias. A bem dizer, as ideias não têm "lugar", nem lá nem cá, servindo, no mais das vezes, a encobrir tudo aquilo que envergonha a razão, uma vez desnudada a injustiça do edifício político (MONTEIRO, 2004, p. 199).

Ao tomar a obra de Silva Lisboa para análise das ideias modernas ali presentes, bem como algumas análises contemporâneas a esse mesmo respeito, é necessário identificar a vasta diversidade cultural que envolve a formação de determinados aspectos do arcabouço conceitual e do discurso da própria elite letrada que viria a compor o universo de pensadores modernos. Por sua vez, no momento de compreender e analisar a recepção desse arcabouço conceitual deve ser levado em conta a respectiva diversidade cultural de formação daquele que recebe, diversidade esta que também recairá sobre o modo como essa mesma recepção construirá o seu próprio discurso.

A se tomar a obra de Rousseau como exemplo de tais posturas de abordagem, é simples notar que, embora quase sempre rechaçada por Silva Lisboa, a obra de Rousseau 
comporta termos e expressões aos quais Silva Lisboa sempre recorre, por exemplo: natureza, liberdade, condição humana e convenções sociais. No entanto, as concepções quase sempre são muito diferentes, por vezes até mesmo opostas, bem como o uso que faz desses termos e conceitos segundo intenções igualmente díspares. Isso não torna possível afirmar que não houve compreensão, ou que tais autores compõem e dialogam com contextos completamente separados e singulares. De de algum modo participam de um mesmo contexto intelectual.

Assim, na obra de Silva Lisboa a adesão às ideias modernas não significa o afastamento em relação a outras formações culturais, a exemplo do discurso religioso. Se Rousseau não mais faz apelo à moral de ordem religiosa, Silva Lisboa o faz, mas nem por isso esteve ele deixando de lado o apelo à razão, cuja origem encontrou nas ideias modernas e no Iluminismo de modo geral. Como demonstrado ao citar aqui novas abordagens sobre formação e objetos de interesse da obra de Isaac Newton, mesmo que de modo introdutório, essa hibridez esteve nas raízes do próprio pensamento moderno, embora essa característica tenha passado desapercebida em muitos estudos sobre a chamada cultura Iluminista, mais complexa do que por muito tempo estimou-se.

Da mesma forma, é necessário compreender não somente os conceitos modernos trazidos à baila, mas também o modo como os mesmos modernos promoveram seu próprio discurso; como convenceram a si mesmos e a boa parte de seus leitores sobre sua cognição do mundo, e o quanto esse convencimento ainda resiste nas pesquisas contemporâneas, como se muitas vezes o pesquisador não fosse capaz de superar o próprio objeto de pesquisa e análise sobre o qual está debruçado, de modo que conceitos e discursos se impõem ao pesquisador mediante uma suposta naturalidade, por vezes muito poderosa. Dicotomias como fé e razão, ciência e religião, muitas vezes impedem a ampliação do conhecimento histórico sobre os próprios modernos. O movimento de ideias em jogo, esse intrincado e rico objeto de estudo para a história das ideias e para a história intelectual, muitas vezes não está dotado de tal simplicidade.

No caso de Silva Lisboa, foi ele mais um homem das letras, como assim eram chamados no século XVIII os intelectuais que pensavam sobre diversas áreas do saber, hoje tão bem delimitadas pelas fronteiras da especialização; embora tenha ficado mais conhecido por seus escritos sobre economia política, foi um intelectual que refletiu sobre variada temática. Diante dessa situação, é vasta a possibilidade de questões acerca dos pressupostos intelectuais de Silva Lisboa, e mais vasta ainda as considerações a serem 
tecidas em relação ao contexto histórico em que esteve inserido e a partir do qual recebeu o ideário dos modernos.

Afirmando seguir a melhor tradição liberal de seu tempo, conforme é possível notar já a partir dos principais títulos de sua obra, Silva Lisboa teve como um dos maiores problemas articular uma sociedade escravista num determinado projeto econômico e mesmo jurídico então tomado como ideal. Uma vontade que se apresentava como civilizadora, uma causa humanitária e mesmo filantrópica, cuja argumentação tantas vezes vinha acompanhada de conceitos por ele tido como universais, tais como indivíduo, Estado, cidadão, e Direito, os quais serviram de temas para centenas de páginas escritas por Silva Lisboa. Mas a pretensa neutralidade tantas vezes projetadas sobre esses conceitos, quando não se via comprometida, ruía diante de si, porque a sociedade em que vivia e sobre a qual refletia estava economicamente baseada na mais horrenda forma de exploração humana.

Silva Lisboa recebeu, apropriou-se e fez uso do ideário moderno a partir de um dado contexto. Do mesmo modo, discursou a partir daquele contexto, dirigindo-se a seus pares quase sempre nele inseridos. Discorreu acerca de uma determinada sociedade, a qual pretendia ver em compasso com a modernidade, sem nunca descuidar do modo como essa mesma modernidade deveria ser alcançada, atento às adaptações e transformações necessárias para tal projeto. Mesmo seu antiescravismo não desconsiderava esse fato. Quando então viesse o que para ele seria a necessária emancipação dos escravos, parece claro que deveria haver o lugar específico para cada tipo de cidadão. Católico, ilustrado, liberal, monarquista, antiescravista, humanitário e filantrópico, antimaçônico e tantas outras facetas compõem o pensamento e o discurso híbrido de Silva Lisboa. Daí a necessidade desse mesmo discurso ser conhecido também segundo sua historicidade. Estudá-lo a partir desse pressuposto, o da hibridez e sua respectiva relação com a conjuntura histórica requer cuidado, esforço e muita atenção, a fim de evitar uma postura passiva diante do discurso que essa própria modernidade compôs acerca de si mesma ao tecer sua própria cognição sobre o passado histórico, o próprio mundo em que viveram e sobretudo acerca do futuro que almejavam.

Sendo assim, é difícil estabelecer relações diretas entre o fato de Silva Lisboa ter deixado os círculos da maçonaria e uma guinada ideológica na trajetória intelectual desse autor. Tal afastamento certamente está relacionado ao fato de que a postura 
contrarrevolucionária de Silva Lisboa havia se acirrado, bem como ao contexto de crise do Antigo Regime de modo mais geral, em especial as transformações ocorridas na relação entre o Brasil e Portugal, diante das quais fora quase sempre conservador em termos políticos, especialmente acerca da ruptura entre metrópole e colônia. Como se sabe, Silva Lisboa tardou a defender a independência política e quando isso de seu, o fez sob condições bastante conservadoras.

Como na matriz europeia, a maçonaria no Brasil sempre esteve ligada ao pensamento liberal e ao pensamento ilustrado de modo geral. Segundo o entendimento de autores como Roque Spencer Maciel de Barros, durante o século XIX a maçonaria brasileira pode ser vista em oposição às correntes de pensamento conservador, cuja principal instituição representante foi a Igreja; formava-se assim a chamada mentalidade católico-conservadora (cf. BARROS, 1986, p. 22). Tentar classificar de um modo imediato Silva Lisboa e sua obra a partir dessa dicotomia é um procedimento problemático, pois foi católico fiel e em larga medida adepto do que viria a ser chamado de liberalismo econômico.

Na introdução da obra Luzes e Sombras: A ação da maçonaria brasileira (1870 - 1910), o historiador Alexandre Mansur Barata tece breve apresentação das origens da maçonaria moderna, na cidade de Londres em 1717: visava formação cosmopolita para pessoas de toda origem e religiosidade, almejando a perfeição através do simbolismo, seja místico ou racional, da filantropia e sobretudo da educação (cf. BARATA, 1999, p. 29). Até este ponto Silva Lisboa poderia perfeitamente estar alinhado a tal proposta, afinal, trata-se de uma sociedade cosmopolita e ele era um homem do Novo Mundo, de um universo colonial, com estreitos vínculos não só ao ideário como também a várias instituições da metrópole. A maçonaria valorizava a educação como meio de aperfeiçoamento humano e Silva Lisboa demonstra tal preocupação em vasta medida. Este mesmo comentário ainda poderia se estender ao problema da razão e do pensamento ilustrado. Silva Lisboa não deveria então ser posicionado ao lado de uma dada mentalidade católico-conservadora.

Ainda nas apresentações introdutórias sobre a maçonaria, Alexandre Mansur Barata passa pela expansão das sociedades secretas pela França no decorrer do século XVIII, local e período em que nota o alcance de sua plenitude como organização. Em sua maioria burgueses, mas também composta por nobres, religiosos e militares; às vésperas da Revolução Francesa estima-se que a maçonaria chegou ali a cinquenta mil iniciados e que 
toda cidade francesa possuísse uma loja. Assim, na França a maçonaria tornou-se mais racionalista, republicana e defensora da liberdade de consciência (cf. BARATA, 1999, p. 32 - 41). Desta forma, se levado em conta a face antirrevolucionária de Silva Lisboa, este autor então ficaria posicionado ao lado da mentalidade católico-conservadora. Classificação que seria corroborada já que em Portugal nota-se um afastamento entre a maçonaria e o Estado, segundo Alexandre Mansur devido à tradicional e histórica aproximação entre o Estado e a Igreja naquele reino. Sendo Silva Lisboa, cada vez mais ligado ao Estado desde os anos finais do século XVIII, teria reproduzido tal afastamento em relação aos círculos da maçonaria.

Levando-se em conta essas extensas observações, orientadas por pesquisas historiográficas, somadas a múltiplos aspectos do contexto e da biografia de Silva Lisboa, chega-se às hipóteses acima a respeito de sua respectiva relação com a maçonaria, sem com isso significar uma guinada intelectual desse autor luso-brasileiro. A despeito do afastamento em relação ao círculos da maçonaria, a partir de sua visão de mundo e do entendimento a que chegara Silva Lisboa a respeito da filosofia natural e da ciência dos modernos, mantinha-se a coerência entre a cultura religiosa e a cultura ilustrada. As questões ligadas à fé estiveram muito presentes antes e após tal afastamento; a defesa da moral religiosa, à qual se debruçou com mais dedicação nos anos finais de sua carreira e de sua vida não excluía seu apelo à razão, o qual também operava antes e após o mesmo afastamento em relação às sociedades maçônicas. O peso maior para se desvincular daquelas sociedades fechadas e secretas parece mesmo residir na postura cada vez mais antirrevolucionária adotada por Silva Lisboa. Em Estudos do bem comum, ao apresentar e tecer pareceres sobre os economistas franceses, menciona o francês Migneret, que em 1802 publicou Considerações sobre a organização social. Ali, Silva Lisboa destaca de modo positivo anseios antirrevolucionários de Migneret, com ênfase nos fundamentos e de ordem religiosa e cristã.

Este escritor, tendo em vista os hórridos estragos que a ímpia seita de Anarquistas e Ateus haviam causado à França, com a infernal tentativa se abolir a Religião Cristã em um Reino que sempre se honrou com o título de Cristianíssimo, aviva nos seus compatriotas a nobre doutrina do seu Grande Político Monstesquieu.

$[\ldots]$ 
Sem dúvida, enquanto todos os homens não forem intimamente convencidos disso, e habitualmente obrarem pelo influxo da ideia, de que há uma Ordem Moral imutável, estabelecida pelo Ente Supremo para o bem da Espécie Humana, e que ninguém a pode impunemente violar; não é possível realizar-se a justiça, abundância, e paz universal, que a Economia Política, com a luz da Religião Cristã, se propõe segurar a todo o orbe habitável, pela franqueza da honesta indústria, e correspondência das Nações, reciprocando seus bens e conhecimentos... (LISBOA, 1819, p. $97-98)$.

Silva Lisboa explicita mais uma vez sua postura antirrevolucionária, ainda que citando Montesquieu, autor estreitamente vinculado ao racionalismo ilustrado, ao mesmo tempo em que sai em defesa da religião cristã, para terminar o parágrafo reproduzido acima aproximando a cultura ilustrada à cultura religiosa. Segundo sua cosmologia, fé cristã e o apelo à razão permaneciam em coerência mediante uma lógica que ele buscou junto a elementos da ciência e técnica, bem como junto á filosofia natural de um modo geral.

... pela adorável Economia da Divina Providência, o Prelo, Astrolábio, Câmbio, Telégrafo, estão hoje em Confederação contra dita Liga Inimiga; e de sua constante aliança é de esperar o Estabelecimento de perfeito Sistema Social. É pois o Economista o auxiliar do Moralista: este com a Catecismo Religioso procura sempre atrair todos os homes à prática das virtudes... (LISBOA, 1819, p. 9).

Porém o Criador fez depender o progresso possível da inteligência dos homens, e consequentemente de sua riqueza, e prosperidade nesta vida, de uma condição essencial, isto é, de se comunicarem e cooperarem na cultura das terras, inquirirem e observarem as Leis cosmológicas, imitarem as obras da Natureza, e viverem em paz, justiça, mutua ajuda, e troco dos frutos da respectiva terra e indústria (LISBOA, 1819, p. 152).

As citações acima encontram-se em Estudos do bem comum. A primeira delas no momento em que o autor apresenta e defende a importância da ciência e das técnicas para o desenvolvimento das nações e dos povos em geral, sob orientação dos propósitos da economia política em trabalho conjunto ao catecismo moral, sob orientação religiosa. Já na segunda, no momento em que apresentava e defendia o que entendia ser a fundamental lei econômica, onde sua orientação religiosa se aproxima da cultura ilustrada a compor uma cosmologia nas quais ambas deveriam confluir. Com tais citações encerra-se esta análise 
sobre a característica híbrida, das múltiplas faces a compor cosmologia e a obra de pensamento de Silva Lisboa, cuja lógica interna ele pretendia alcançar em boa medida junto a métodos, conceitos e teorias que encontrara na filosofia natural. 


\section{Capítulo 3}

\section{Moral religiosa, economia política e bem comum}

Publicada pela Imprensa Régia entre 1819 e 1820, Estudos do bem comum e economia política ou ciência das leis naturais e civis de animar e dirigir a geral indústria e promover a riqueza e prosperidade do Estado, de autoria de José da Silva Lisboa, foi tida como obra voltada aos estudos da economia política, então muito em voga nos circuitos intelectuais do período. No entanto, se este é o problema que salta aos olhos do leitor de modo mais explícito, também é possível considerá-la uma obra voltada a outras temáticas, a exemplo da moral, conforme o próprio autor sugere. Por sua vez, este texto tomará para análise Estudos do bem comum e projetará questões acerca das concepções de Silva Lisboa sobre a formação social brasileira, naquele efervescente contexto que antecedeu a independência política brasileira.

Aqui será retomada a hipótese de que os elementos da filosofia natural presentes na cosmovisão de Silva Lisboa possibilitaram ao autor uma aproximação entre a moral religiosa e a economia política, a fim de promover as condições necessárias ao bem comum. A sociedade almejada por Silva Lisboa seria alcançada segundo a orientação dos preceitos da economia política, cuja aplicação deveria ser condizente e mesmo submetida a uma dada moral religiosa. A aproximação entre essas áreas do saber ele pretendia ter alcançado através de elementos teóricos e conceituais encontrados na filosofia natural, os quais ocupavam lugar central em sua visão de mundo. A projeção dos conceitos de ordem universal sobre particularismos da sociedade brasileira levou Silva Lisboa a paradoxos que este capítulo pretende identificar e explorar.

Estudos do bem comum também reflete a passagem de Silva Lisboa pela Universidade de Coimbra. Luso-brasileiro natural de Salvador, capitania da Bahia, ali regressou para assumir cargos como os de ouvidor, professor régio e deputado da Mesa de 
Inspeção da Agricultura e do Comércio, quando em 1808 acompanhou a Corte portuguesa rumo à Baía de Guanabara. Já no Rio de Janeiro, foi nomeado diretor e censor da Impressão Régia e deputado da Junta do Comércio. Também atuou de modo intenso e frequente na imprensa, na política e enquanto autor de uma volumosa obra votada à diversificada temática. Em Estudos do bem comum reside um esforço de síntese de suas leituras e experiência, como também um apelo de orientação àquela nação rumo a emancipação política; esforços que tiveram continuidade durante e após o processo de independência.

Acerca dos posicionamentos em relação à atuação política e à obra de Silva Lisboa, em meio à farta bibliografia poderíamos citar as menções de Afonso Arinos, que chamando-o pelo título recebido em 1826, lembra que o Visconde de Cairu desde há muito vem sendo alvo do interesse de pesquisadores, cujo resultado de suas respectivas análises geraram críticas para cima e para baixo, muitas vezes marcadas pelo exagero. Por um lado, segundo Tristão Ataíde, Cairu fora considerado alto símbolo da cultura nacional; já o renomado Sérgio Buarque de Holanda, a dizer ao modo de Afonso Arinos, negou a Cairu pão e água (cf. FRANCO, 1947, p. 87).

A obra em questão, Estudos do bem comum, pode certamente ser colocada entre os trabalhos de Silva Lisboa que possibilitaram conclusões bastante diferenciadas, talvez em oposição extremada. Os anos anteriores à publicação dessa obra são justamente aqueles que antecederam a independência política do Brasil. Ao se tomar Estudos do bem comum como principal objeto das análises a serem realizadas neste momento, também é ponto de partida o pressuposto, já de certo modo indicado pela historiografia, de que é possível identificar ali indícios de uma dada visão sobre aquela sociedade. Indícios suficientes para o enriquecimento do conhecimento histórico acerca do ideário daquele contexto, uma melhor compreensão dos projetos elaborados para aquela futura nação já repleta de problemas de enorme complexidade que de modo direto ou indireto foram mais uma vez tratados por Silva Lisboa.

Relacionar Estudos do bem comum à temática da formação social, admite-se, não consta entre as possibilidades mais imediatas oferecidas pela obra, no entanto, tendo a visão de mundo mais geral do autor como interesse de uma pesquisa mais ampla, neste texto foi possível sim perguntar por questões dessa ordem. Afinal, a ideia de compreender a visão mais geral ou a cosmologia de Silva Lisboa passa pela investigação de suas 
concepções a respeito da sociedade, e pode apresentar resultados satisfatórios na medida em que tal tarefa pretende ser realizada a partir de leituras atentas ao cruzamento de áreas do saber que hoje encontram-se bem delimitadas, mas naquele contexto e mediante a visão do próprio Silva Lisboa não eram vistas assim.

Em meio a problemas ligados à economia política, Silva Lisboa destaca outra face da mesma obra, conduzindo o leitor a questões acerca da moral e a partir das quais, muitas vezes de modo indireto ou mesmo difuso, expõe suas concepções a respeito da sociedade brasileira. Já nas páginas iniciais, o autor aponta a problemática da moral entre suas preocupações. Como é típico em suas análises, Silva Lisboa salta de um comentário introdutório, que ao leitor atual pode parecer dotado de um espírito prático, para outro um tanto especulativo, de ordem moral, religiosa ou mesmo metafísica. Alerta o leitor a respeito do teor e objetivo da obra que está prestes a iniciar.

Não se espere que fatigue o público sugerindo planos de visionária prosperidade, que o Sistema do Mundo visível não admite, e ainda menos à vista do evidentemente decaído estado da constituição da humanidade; nem que iluda aos aspirantes a fortunas com esperanças de opulência sem indústria honesta ativa, e bem dirigida, e ainda menos com generalidade e igualdade nos objetos de gozo não essenciais à vida natural e civil (LISBOA, 1819, PREFÁCIO).

A condição humana a que faz menção o autor é fundamentada na concepção cristã acerca do pecado original, a qual ele utiliza junto a observações de cunho prático, a exemplo das aspirações por fortunas e por uma prosperidade visionária, distante das possibilidades materiais que o mundo sensível não permitiria admitir. Silva Lisboa discorrerá a respeito das riquezas disponíveis e sobre aquelas a serem alcançadas pelo Brasil, mas alerta desde os primeiros movimentos de seu texto sobre as condições a partir das quais essa riqueza será almejada. A investigação sobre tais condições misturam, em um único conjunto de observações e argumentos, preocupações materiais, religiosas ou mesmo metafísicas, para então desembocar em uma dada ideia a respeito da vida civil, ou seja, em aspirações ligadas ao modelo de organização social, econômica e política que espera para aquela nação, às vésperas da sua independência.

Nesse imbricado conjunto de concepções, o problema da moral, que na obra divide espaço com farta diversidade temática abordada pelo autor, já havia sido mencionado em seus parágrafos anteriores. Mais adiante, surge de modo literal e reitera a 
possibilidade de que esta pesquisa pudesse destacá-lo. Ao mencionar a importância da escola inglesa, formada por nomes como Adam Smith, Thomas Malthus e David Ricardo, cuja citações, embora acompanhadas quase sempre de uma leitura crítica, são recorrentes ao longo de toda a obra, Silva Lisboa começa a expor sua visão de mundo, a partir da qual passa a discorrer acerca do funcionamento da ordem social.

Todos estes insignes mestres fazem ver, que, na ordem social nada é vago e arbitrário e tudo depende de Leis constituídas pela Inteligência Infinita que ligou o físico ao moral, e segurou a observância das mesmas Leis por imutáveis sanções de miséria ou felicidade, vida ou morte, dos indivíduos ou Estados (LISBOA, 1819, PREFÁCIO).

Ao autor, o físico e o moral estão associados segundo a leitura que faz dos mestres em que se apoia. Sua visão geral de mundo concebe uma cosmologia na qual uma Inteligência Infinita imprimiu no mundo leis responsáveis por relacionar aspectos, à primeira vista tão díspares, mas cuja relação influi diretamente no sucesso dos indivíduos e mesmo dos Estados. Desde o primeiro capítulo, a abrir a extensa primeira parte de Estudos do bem comum, Silva Lisboa explicita sua preocupação em compor análise e argumentação a partir de uma economia política que pretende ser generalizante, dotada de princípios razoáveis, cujo conhecimento é necessário à condução do desenvolvimento, necessário à identificação e prosperidade da riqueza da nação.

A economia política se apresenta ao autor como uma possibilidade de síntese explicativa. Tal ciência orienta seu entendimento e, mediante as concepções que ali encontra, a moral atua como mais um determinante, um meio necessário para ao menos se aproximar da perfectibilidade social que está sendo almejada, sem a qual a própria riqueza estaria comprometida. O problema da riqueza da nação passa a todo momento por questões acerca da moral, rumo a uma determinada ordem social. Abaixo, é possível notar que Silva Lisboa demonstra conhecer de modo bastante razoável o contexto intelectual a que se refere e com o qual dialoga. Se anteriormente citou autores de reconhecida propriedade em economia política, em seguida, aponta algumas das principais matrizes da teoria e método que compartilha e onde residem as origens epistemológicas dessa mesma escola de pensamento, apontamentos e comentários que mais uma vez confirmam não somente a razoabilidade, mas a necessidade de se projetar sobre seus textos as questões que a presente análise pretendeu explorar. 
Agora convém que nesta parte do Novo Mundo não se estime somente a Geórgia do Território, mas também a Geórgia do Espírito, conforme a frase e lição de Bacon, que, com o seu Novo Órgão das Ciências, deu o mais espiritual sopro aos estudos úteis das nações modernas, ensinando o seu método analítico de achar a verdade, por observações e experiências de fatos que estão aos olhos do mundo, para deles se deduzirem os sólidos Princípios e Sistemas que regulem a Sociedade (SILVA LISBOA, 1819, p. 07).

A menção à obra de Francis Bacon e ao método analítico conduz o leitor à escola empirista inglesa, cujo nome de maior expressão é o de Isaac Newton. Ainda que sem considerar aqui as diferenças epistemológicas e conceituais entre as propostas metodológicas, o que fora chamado de resolução e composição por Bacon e análise e síntese por Newton, de modo introdutório e generalizante, é tomado por Silva Lisboa a fim de destacar sua preocupação em adotar uma dada postura epistemológica, o empirismo, nos estudos acerca da economia política e do próprio bem comum que então se colocava a apresentar. A observação e a experiência, a partir de fatos que estão aos olhos do mundo, permitiram a dedução, a composição, a síntese, dos princípios e sistemas reguladores da sociedade. A passagem acima é mais uma explícita alusão ao paradigma newtoniano, tido como matriz epistemológica de muitos mentores de Silva Lisboa em economia política, a exemplo do próprio Adam Smith.

Se a filosofia natural conferiu uma postura mais crítica e razoável à produção do saber, como reconhece Silva Lisboa, a moral surge para apontar a melhor direção de seu emprego: o bem da humanidade, o bem de todas as nações. Assim, é necessário questionar sobre as condições em que problemas acerca da moral estariam inseridos nessa cosmologia. A partir do subtítulo Necessidade e importância dos estudos do bem comum, Silva Lisboa sinaliza essa relação entre o conhecimento e a moral. Ainda que não dotado de clareza suficiente, abre o capítulo com apelos dessa natureza, além de adiantar sua declarada aversão à revolução social enquanto uma de suas maiores preocupações. A partir de uma cosmologia que reúne aspectos da filosofia natural, da moral e tantos outros elementos, discorrerá sobre a economia política, mirando uma determinada ordem social, dotada de elementos conservadores cuja identificação e análise muitas vezes não parece ser simples. 
O terrível choque que a Europa e América sofreram no fim do século passado, e que abalou os fundamentos da esperança, da 'Perfectibilidade Social', atrasando os estudos úteis para esse destino, e até sugerindo indiferença e desconfiança ao adiantamento da inteligência humana, ainda nos objetos de imediato interesse à vida e paz geral, impossibilitou dirigir-se a atenção dos estudiosos para inquirição dos eficazes meios da prosperidade pública, fundados nas Leis do Sistema Cosmológico, de cujo conhecimento deve resultar o maior bem possível da Humanidade, e de qualquer Nação (SILVA LISBOA, 1819, p. 6).

Assim, Estudos do bem comum trata, de modo conciliatório e reciprocamente determinante, os problemas acerca da riqueza da nação e a necessidade de evitar a revolta social. Referindo-se às Revoluções Francesa e Americana como interrupções dos possíveis avanços que o conhecimento deveria conferir ao destino dos povos, Silva Lisboa chama a atenção para a possível prosperidade pública que esse mesmo saber poderia conferir às nações, uma vez que a partir dele seria possível identificar leis de um sistema cosmológico, para melhor buscar a perfectibilidade social, ainda que esta última expressão encontre-se entre aspas.

O bem comum deve ser buscado a partir da economia política, conhecimento proveniente da Ilustração, sob reconhecida influência do paradigma da filosofia natural de matriz inglesa, mais propriamente newtoniana, a compor uma cosmologia na qual também estiveram inseridos como determinantes os elementos morais e religiosos, a formular uma argumentação cuja lógica interna não deveria perder de vista a preocupação em evitar revoluções sociais. Tais são as condições em que a moral esteve inserida em sua cosmologia, ligada a suas preocupações de cunho social. Para Silva Lisboa, a moral possuía sobretudo a função educadora, muitas vezes dotada de certo otimismo e positividade.

É notório e já muito analisado o impacto que as revoluções mencionadas por Silva Lisboa imprimiram sobre a política, a economia e mesmo sobre o imaginário do período histórico em que estiveram inseridas e de períodos ainda vindouros ${ }^{59}$. É de igual conhecimento que tal impacto assumiu feições características a cada contexto em que se dava. Ainda que em franco diálogo com escolas de pensamento europeias e a compartilhar

\footnotetext{
${ }^{59} \mathrm{O}$ tema da repercussão da Revolução Francesa é muito recorrente e de abordagem temática muito variada. Em se tratando de Brasil e América Latina, cabe citar a obra A Revolução Francesa e seu Impacto na América Latina, que reúne artigos de diversificada temática e orientação, sob organização do professor Osvaldo Coggiola (cf. COGGIOLA, 1990).
} 
conceitos e métodos tidos por ele como universais, Silva Lisboa produziu suas análises tendo em vista especificidades do contexto em que viveu; seu interesse maior residia na situação do Brasil, então ainda ligado ao Império Colonial Português. Nesse cruzamento entre o geral e o particular, se viu diante de paradoxos que sua obra de pensamento não pode evitar.

O impacto das revoluções está entre as preocupações centrais de Silva Lisboa. O bem comum deve ser alcançado sem revolução social, bem como a fim de evitar a revolução social. Sob seu julgo, bem comum e revolução não condizem. A sociedade deve ser educada para o espírito antirrevolucionário. Como há pouco foi afirmado, a leitura atenta da obra Silva Lisboa permite identificar ali a missão educadora da moral. Neste ponto reside uma das mais importantes funções da moral, mas nem por isso torna-se tarefa simples classificar Silva Lisboa como um mero conservador. Sua postura avessa à revolução não o levou a um conservadorismo simplista. Se por um lado pode ser difícil compreender a fundo suas concepções, por outro é certamente mais promissora tal compreensão do que estabelecer classificações imprecisas, porque apressadas.

Mediante tais condições apresentadas pelo próprio autor, a partir de então estará de certo modo isolada a relação entre a moral e a riqueza da nação, para assim buscar alguma compreensão histórica mais apurada sobre o que concebia Silva Lisboa acerca da sociedade brasileira. Para isso, cabe destacar eixos temáticos, a partir dos quais a relação entre moral e riqueza da nação conduzirá esta análise às concepções de Silva Lisboa a respeito da sociedade brasileira.

\section{Discursos de síntese. Filosofia natural, moral e religião.}

De modo introdutório, já foi possível notar em Estudos do bem comum a filiação de seu autor a uma postura epistemológica tributária do empirismo inglês, seu apelo à escola clássica de Smith, Malthus e Ricardo, atuando em conjunto com uma visão de mundo marcada por diversificadas concepções, em especial aquelas ligadas à sua religiosidade cristã, elemento determinante na condução de toda sua obra. Segundo o entendimento de Silva Lisboa, como já apontado, a condição humana estava marcada, antes de mais nada, pela concepção cristã do pecado original. Ainda que promissora e adotada com espírito de otimismo, a economia política deveria instruir a construção da 
riqueza nacional a partir dessa situação predeterminada, conforme a orientação da religiosidade cristã e católica a que se filiava Silva Lisboa, impondo assim a necessidade de uma moral de destacada finalidade educadora.

Sua cosmologia pretendia ser capaz de conciliar tais elementos à primeira vista tão díspares. Tal conciliação ou mesmo coerência interna só foi possível a partir da filosofia natural compartilhada por Silva Lisboa, conforme já explorado anteriormente sob título O pensamento híbrido de Silva Lisboa. Ali, espera-se ter apresentado de modo suficiente que a cosmologia de Silva Lisboa comportava conceitos tidos como de caráter universal apropriados junto à filosofia natural mais comum entre o pensamento ilustrado, evitando incoerências junto à sua religiosidade cristã. Assim, adotara a economia política, a ciência que encaminharia discussões acerca da riqueza nacional, sem com isso afastar-se da moral de cunho cristão. A sociedade pensada e almejada por Silva Lisboa deveria estar delimitada por esses moldes.

Avançando a análise segundo a temática sugerida, encontramos em Estudos do bem comum passagens onde mais uma vez é possível notar a relação entre o problema da riqueza da nação e a moral cristã a partir de um arranjo conceitual retirado da filosofia da natureza. Já no prefácio da obra, Silva Lisboa reconhece na economia política o caráter de ciência, e atribui à mesma um destino transcendente. No primeiro capítulo, intitulado Necessidade e importância dos Estudos do Bem Comum, a mesma economia política é novamente apresentada a partir de sua capacidade de transitar entre saberes diversos.

... é inquestionável a mútua dependência com que se ligam todos os ramos das ciências; contudo é não menos certo, que alguns são de tão fundamental interesse, que, sem os seus estudos, nenhum dos outros pode prosperar, e nem ainda consideravelmente existir. Este caráter, depois dos estudos da Religião Cristã, com justiça pertence aos de Economia Política (LISBOA, 1819, p. 06).

O autor sugere que a economia política é uma ciência de síntese e só não mais imprescindível que a própria religião cristã, pois capaz de relacionar os saberes diversos, incluindo a literatura, segundo ele muitas vezes utilizada com exagero, mas necessária à ciência. Contrariando interpretações que atribuem a Silva Lisboa radical preponderância do trabalho intelectual sobre os afazeres manuais, de ordem prática, segue sua explanação reconhecendo a necessidade de que as artes mecânicas tenham gerado alguma riqueza 
material, para que então alguns pudessem se dedicar ao estudo das leis e obras do Criador. Para corroborar sua tese, passa a citar fontes de natureza diversa. Faz menção ao Eclesiastes, mas lembra também de frases atribuídas a Alexandro Magno, por meio de escritos deixados por um dos primeiros donatários da colônia: primeiro é enriquecer, $e$ depois filosofar (cf. LISBOA, 1819, p. 07).

As citações de mais variada ordem seguem em frente; Silva Lisboa levará ao leitor fragmentos da obra de Montesquieu, para então chegar aos pensadores ingleses e concluir retomando seu cristianismo. Em sua cosmologia, toda essa diversidade deveria encontrar uma disposição harmônica, cujo limite em breve fará saltar aos olhos contradições nem sempre tão aparentes. Chega a tomar Espírito das Leis para mencionar a capacidade de unificação da religião cristã que é identificada a partir da caridade, dos cultos públicos e dos sacramentos. Tal religiosidade se apresenta ao autor como o terreno ideal para os objetivos da ciência da economia política; embora não afirme de modo literal, permite supor que se trata de uma condição necessária. Silva Lisboa também enfatiza a fidelidade de Portugal à tal religião, o que entende ser mais um fator positivo para a adoção dos princípios da economia política e a construção do bem comum no império lusitano (cf. LISBOA, 1819, p. 07).

Ainda em Estudos do bem comum, quando passa a tratar a respeito da própria economia política, faz opção pelos autores ingleses, a fim de destacar a construção do bem comum que essa ciência poderia orientar. Sinaliza o desejo pela formação de um comércio universal, benevolente e pacificador de todas as comunidades, a partir de ideias gerais que atribui ao moralista Thomas Gisborne.

... propagar a Lei Evangélica de Luz e Revelação às Gentes para a glória de Deus, e paz aos homens benévolos, visto que um dos veículos de execução destas Leis é o Comércio franco legítimo, que tende a animar, bem dirigir, e generalizar os trabalhos úteis da Cooperação Social, e dar o maior recíproco valor aos frutos da terra e indústria de todos os Países (LISBOA, 1819, p. 08).

Passa a citar literalmente o mesmo Thomas Gisborne, agora indicando a obra Inquirição dos deveres dos homes, para reafirmar a estreita relação entre o transcendente propósito do comércio, cujo destino fora dado pela Providência com a finalidade de promover um leque de benfeitorias, tais como o cultivo da terra, a extração de seus 
tesouros, aguçar a indústria do homem, unir a espécie humana em laços de fraternal conexão, além do que entende ser muitas outras benesses, com lugar ao progresso da civilização, a extensão da ciência e a recepção do cristianismo. Aproximando-se do final de sua argumentação acerca da necessidade e importância dos estudos do bem comum, Silva Lisboa volta a enfatizar a estreita relação entre a riqueza das nações e a moral que lhe é proveniente da religiosidade cristã. Identificar e promover os princípios da economia política faria avançar ao último fim, a que todos os desígnios e dispensações de Deus, bem como raios de luz convergentes a um ponto central, parecem evidentemente dirigidos, ao aumento da soma da Geral Felicidade (cf. LISBOA, 1819, p. 08).

A economia política e a fé cristã se encontram e mesmo se complementam na cosmologia de Silva Lisboa através de um conceitual apreendido junto à filosofia natural. Sua visão geral de mundo não identifica contradições entre culturas tão diferentes. Considerando o que está sugerido desde o prefácio da obra e já explorado aqui, no funcionamento da sociedade que Silva Lisboa extraíra dos mestres ingleses nada seria vago e arbitrário, mas sim em conformidade com leis constituídas pela Inteligência Infinita que ligou o Físico ao Moral. A identificação e esforço para estar em conformidade a tal legislação cabe à ciência da economia política (cf. LISBOA, 1819, PREFÁCIO). Resta investigar o paradigma de sociedade que surgirá dessa relação por ele concebida entre o problema da riqueza das nações e o problema da moral.

Já no segundo capítulo da primeira parte de Estudos do bem comum, sob explícita orientação da economia política de Adam Smith, afirma que a sociedade civilizada deveria estar composta por três classes, a saber: proprietários, capitalistas e assalariados. No desenrolar do mesmo capítulo, analisa que o surgimento e a formação dessas classes teria complicado o que chama de Sistema Social. Mesmo sem aprofundar investigações acerca das classificações elaboradas pelo autor, cabe levantar algumas questões a partir da apropriação que fez Silva Lisboa de um conceitual retirado da filosofia natural. De antemão, nota-se o emprego do termo e mesmo do conceito de sistema; a partir dele pressupõe a existência de leis a serem identificadas para melhor explorar seu funcionamento. No entanto, as classes também são apresentadas como fruto de uma dada transformação, remetendo o leitor à ideia de processo histórico. Isso imprime alguma coerência interna ao conceito de civilização, também presente no trecho em análise (cf. LISBOA, 1819, p. 10). 
Assim concebido, o autor projeta um tempo histórico bastante dilatado, traz à tona especulações a respeito das mais antigas formas de organização social, para encaminhar, de modo um tanto resignado e conforme uma postura a ser analisada no capítulo seguinte deste trabalho, a conclusão de que a dita transformação trouxe desigualdade de condições e fortunas, conflitos de interesse e direito, diante do que surgiu a necessidade um Estado regido por leis, a substituir organizações anteriores, por ele vistas como mais simples e ali exemplificadas a partir das antigas sociedades patriarcais e tribais, de origem remota, tidas pelo mesmo autor de modo idílico, ainda que não tenha estendido comentários a esse respeito (cf. LISBOA, 1819, p 11, 12).

Ao ampliar o questionamento, é razoável concluir que segundo a coerência interna que Silva Lisboa pretendeu conferir à obra, o instrumental oferecido pelas teorias a que se filiava também encontrava limites para suas generalizações diante do processo histórico. As classes, a constituir a mencionada civilização, seriam todas fruto de um processo transformador ocorrido ao longo do tempo. Porém, se a análise permanecer limitada ao capítulo em questão, sob título Origem da ciência da economia política, o quase absoluto silêncio do autor acerca do caso brasileiro é suficiente para uma possível frustração inicial dos pesquisadores voltados à temática semelhante. Muito pouco surge a respeito da sociedade a que o próprio autor pertencia. O modelo analítico por ele adotado parece ser, à primeira vista, por demais generalizador para ser projetado sobre tantos particularismos.

Afinal, um dos maiores problemas a ser resolvido por Silva Lisboa seria o de deslocar suas considerações teóricas, explorando possibilidades de execução do projeto de civilização idealizado a partir do surgimento das mencionadas classes, sobre uma situação local cuja maior característica era persistência e predominância do trabalho escravo. O autor apenas esbarra no tema, sem qualquer menção ao Brasil, para encerrar o capítulo exaltando os modernos, a quem coube o início de uma formulação mais precisa da economia política. Enquanto descreve o processo de surgimento da desigualdade, e de alguma forma contextualiza a origem remota da economia política, passa pelo tema do escravismo.

... o intitulado Direito das Gentes, que autorizou o reduzir à escravidão os prisioneiros de guerra, sem distinção de ser esta justa, ou injusta. Os 
vencedores se intitularam senhores, e os vencidos ficaram cativos perpetuamente, transmitida a sua condição aos filhos.

Os antigos Estados fizeram a distinção civil entre livres, escravos e libertos [...] Por esse simples expediente se formou a geral subordinação e se assegurou a subsistência, defesa e riqueza das Nações. Porém ao mesmo tempo se organizou a extrema desigualdade das condições, e a inexterminável indigência e miséria dos povos; sendo os respectivos governos mais ou menos regulares, ou despóticos, conforme os graus de civilização, que a Religião, o Comércio, e os estudos das Letras, foram lenta e gradualmente introduzindo. (LISBOA, 1819, p. 12).

Embora reconhecendo que a partir dela se fez a riqueza de antigas nações, imediatamente após o momento em que surge a crítica à desigualdade, que segundo o desenrolar da própria obra estará mais bem exemplificada pela condição de escravo, Silva Lisboa volta a relacionar a ciência da economia política à moral religiosa. Ambas atuaram na caracterização dos antigos governos e suas respectivas participações estiveram diretamente relacionadas ao chamado processo de civilização. $\mathrm{O}$ autor não passa sequer pelo termo Brasil, muito menos faz qualquer emprego direto dos conceitos de sua teoria geral sobre os particularismos do regime escravista de sua terra natal, todavia, está registrado ali que a ciência e a moral religiosa, tomadas por ele como linhas mestras de sua cosmologia, também possuiriam a finalidade de instrumentalizar a superação do escravismo, na medida em que o comércio e religião atuariam como agentes em um processo histórico rumo à civilização, segundo o qual essa forma de trabalho e divisão social deveriam ser superados.

Sim, Silva Lisboa pode ser tratado como um conservador, mas seu conservadorismo não é uma mera obviedade. Em artigo publicado pela Revista de História, Pedro Meira Monteiro ${ }^{60}$ traz questões acerca do caráter conservador que de modo recorrente foi atribuído a Silva Lisboa pela historiografia. Intitulado $O$ 'reacionário', o texto já encaminha o problema a partir de seu subtítulo em forma de questão, Muitos historiadores falam mal do Visconde de Cairu. Será que ele merece isso? Deste modo, Meira Monteiro reconhece o fato de que Silva Lisboa tem sido mais detratado do que reconhecido ao longo da história, mas prefere chamar a atenção ao seu caráter polêmico e contraditório, observação que pretende estar justificada ao reconhecer em Silva Lisboa um

\footnotetext{
${ }^{60} 0$ 'reacionário'. Muitos historiadores falam mal do Visconde de Cairu. Será que ele merece isso? Artigo publicado em agosto de 2008 pela Revista de História da Biblioteca Nacional. Consultado em 8 de julho de 2014. IN: http://www.revistadehistoria.com.br/secao/retrato/o-reacionario.
} 
convicto defensor do liberalismo econômico e ao mesmo tempo sua imensa preocupação com o controle social (MONTEIRO, 2008).

Embora esta pesquisa prefira não utilizar o termo contraditório sem devidas ressalvas, tende a concordar de modo geral com a necessidade de se compreender o caráter polêmico da obra de Silva Lisboa, de modo a esquivar-se de respostas imediatas, quase sempre fruto de questões muito simplificadoras. Silva Lisboa possuía em seu horizonte a necessidade de abandonar o problema do escravismo e o fez. A análise a respeito de tal condição econômica, social e mesmo moral, assim como a própria necessidade de sua superação, estavam submetidos a uma visão geral de mundo, uma cosmologia, a qual comportava elementos culturais dispostos segundo uma coerência interna que ele acreditava estar conferindo à sua obra.

Através dessa cosmologia, na qual a filosofia natural muitas vezes operava como uma espécie de matriz conceitual, ele entendia estar elaborando uma literatura dotada de alguma lógica interna. Muitas vezes foi e poderia continuar a ser tratado como conservador, se comparada sua proposta de superação do escravismo a outras também debatidas em seu tempo, como será possível notar adiante, entretanto, tal classificação não parece ser muito esclarecedora. Faz-se necessário compreender a própria lógica de seu discurso, fazer saltar aos olhos seus limites internos, cuja identificação e análise é imprescindível, sobretudo a todos aqueles que possivelmente estejam interessados em julgar a obra e até mesmo o autor, que se esforça para elaborar a apresentação e mesmo a defesa das propostas de uma economia política de cunho liberal sobre uma sociedade cuja condição escravista está sendo por ele criticada, sem com isso deixar de lado aspectos que se comparados a outras propostas de superação não deixa de ser conservador.

Atendo-se a essa proposta, é possível notar ao longo do texto que a ciência da economia política passa a ceder espaço à argumentação de envergadura moral. Na medida em que esta pesquisa projeta seu interesse ao emprego de conceitos da filosofia natural sobre a relação entre esses dois campos do saber, economia política e moral religiosa, é possível conduzir a análise à problemática da sociedade e as transformações necessárias conforme o entendimento de Silva Lisboa. Tal procedimento traz à tona os limites quando os conceitos de ordem geral deparam-se com obstáculos encontrados junto aos particularismos de uma sociedade caracterizada pelo modelo escravista. 
Os limites da síntese na projeção de uma sociedade.

Nos momentos em que diante dos problemas apresentados pelo caso brasileiro, a formação histórica que era de maior e especial interesse do autor, parecia restar do instrumental teórico da economia política apenas a terminologia, Silva Lisboa então se desdobra a fim de aproximá-lo de modo mais estreito aos problemas da moral. Para essa tarefa, faz uso de conceitos tidos como universais, sendo possível notar sua necessidade em compartilhar uma ideia central à filosofia do Iluminismo. Salta aos olhos a clareza com que Silva Lisboa explicita a ideia de universalidade do gênero humano; mais do que apenas fazer uso de uma premissa teórica embutida em suas análises, o autor preocupa-se em apresentá-la ao leitor. Trata-se de uma postura típica de parte considerável dos intelectuais de seu tempo, tributários de uma concepção estreitamente ligada ao ideário ilustrado, a ideia de natureza humana, hoje sujeita a críticas diversas, mas que ainda ocupava lugar central nas investidas filosóficas no início século XIX.

Sendo, a constituição humana homogênea em todos os países, a mesma Lei deve reger em todas as Nações, ou Estados, que se podem considerar outras tantas Casas particulares, ou ramificações de Famílias, oriundas dos mesmos pais. Circunstâncias do lugar e tempo podem necessitar algumas acidentais, mas não substanciais, modificações daquela Lei (LISBOA, 1819, p.138).

Nesse sentido, já na segunda parte de Estudos do bem comum, sob sugestivo título Princípios fundamentais da economia política, e cooperação social, o autor passa a estabelecer tais relações, a serem projetadas de modo universal.

Economia Política geral tem por objetivo inquirir o Verdadeiro Sistema Social, fundado nas Leis Fundamentais da Ordem Moral, isto é, o Plano Econômico do Criador, e que se diz Economia da Providência a respeito da Espécie Humana, a fim de ter fundos do necessário cômodo, e delicioso à vida, além dos que a Natureza espontaneamente produz, e oferece nas terras e águas que a cobrem; e, em consequência, para se poderem os homens multiplicar, e bem conviver na sociedade, aperfeiçoando os respectivos dotes de espírito, e corpo, quanto é compatível com a sua atual constituição, evidentemente decaída de seu primordial estado (LISBOA, 1819, p. 140). 
Segundo sua cosmologia, a filosofia natural promove a possibilidade de estabelecer a relação, segundo ele necessária, entre a riqueza da nação, sob orientação da economia política, e a moral, sob orientação de sua religiosidade cristã, conforme a coerência que impôs ao texto desde os primeiros parágrafos. A ideia de leis fundamentais, uma das balizas mestras da filosofia natural dos modernos, deve operar nos estudos encaminhados pela economia política, cujo propósito envolve perguntar acerca do sistema social, a respeito do mecanismo que, em última instância, trata-se de um Plano Econômico do Criador. O conceitual aprendido junto à filosofia da natureza opera de modo a aproximar ciência e religiosidade. Tal postura permite apontar em sua formação intelectual a profunda influência das Reformas Pombalinas na Universidade de Coimbra, onde Silva Lisboa esteve entre 1774 e 1779, quando então retornou à colônia.

Dando continuidade à sua explanação, Silva Lisboa estabelece distinções entre o que chama de economia política geral e economia política particular, sendo aquela voltada ao progresso geral da civilização, e esta última à tarefa de promover a indústria e riqueza nacional. Neste ponto reside os limites impostos à sua teoria pela formação histórica e social de cada nação, ou seja, dos casos particulares. Silva Lisboa demonstra ter claro para si as dificuldades de submeter o caso particular aos conceitos de ordem geral, embora enfatize que seu interesse reside sobre o caso nacional, o caso do Brasil, naquele momento pensado por ele ainda como extensão do império português.

\begin{abstract}
Ainda que vários Princípios de Economia Política Geral sejam certos, e luminosos, todavia eles consideravelmente se modificam e restringem-na sua aplicação às operações do Governo de cada Nação, pela necessidade de se atender as ditas considerações. $\mathrm{Na}$ verdade, quando ainda os melhores e mais incontestáveis princípios especulativos de Economia Política se aplicam aos usos práticos da vida civil, eles passam (por assim dizer) pela densidade dos intrincados costumes, hábitos, estatutos, erros, estabelecimentos, e prejuízos inveterados dos povos... Por isso não é sempre possível, ou seguro, aplicar (cega e indiscriminada, e absolutamente) tais princípios, tanto na direção da indústria de cada país, como no seu regime econômico; e, em consequência, pode ser este mais ou menos liberal (sem nota contra a sabedoria da Administração) conforme aos lugares, circunstâncias, e relações com os diversos Povos e Governos (LISBOA, 1819, p. 142).
\end{abstract}

Embora esteja a tratar dos princípios fundamentais, com muita clareza Silva Lisboa adverte seu leitor acerca da necessidade de se levar em conta as condições específicas de cada nação, no momento em que cada uma delas fossem submetidas a tais 
princípios gerais. Cita um leque diversificado de eventuais particularismos, a exemplo de hábitos, densidade dos costumes, estatutos, estabelecimentos. Contudo, ainda que mais uma vez não mencione diretamente o Brasil, estende suas exemplificações trazendo à tona o que para ele era em sua nação o mais pertinente dos particularismos, e ele é de cunho sobretudo econômico e social.

É óbvio, que uma Nação de povos incultos não pode ter igual economia política, que uma de gente civilizada, e adiantada em artes e ciências. Não pode também ser exatamente a mesma economia política, em uma Nação onde se acha estabelecida a Lei do cativeiro, ou da servidão da gleba, e em outra onde os povos gozam de plena liberdade civil, e fazem bom uso dela (LISBOA, 1819, p. 142).

De início, cabe destacar que no trecho acima o autor utiliza a expressão economia política, escrevendo as inicias em letras minúsculas. É possível entender que sua intenção era distinguir tal utilização no contexto particular, acima citado, daquelas onde buscou mencionar a ciência de mesmo nome, dotada de seus reconhecidos princípios de ordem geral. Além dessa rápida observação, deve ser registrado aqui a comparação que é sugerida pelo autor. Novamente, é possível concluir que Silva Lisboa tinha o escravismo como a condição social, econômica e moral mais oposta à condição de civilização. No que diz respeito ao processo histórico, a existência de um sistema escravista era o fator que mais comprometia o projeto civilizatório, a ser buscado a partir dos princípios da economia política e para a realização da cooperação social, cuja finalidade maior seria alcançar o bem comum.

A partir dessa lógica, à sociedade escravista que é então analisada cabe a necessária superação, porém, sem drásticas rupturas, sobretudo aquelas de caráter revolucionário. Sendo assim, caberá encaminhar um processo histórico que jamais deixe de considerar as leis que a divindade estabeleceu para o progresso das nações e de toda a humanidade. A identificação e a observância dessas leis estão entre as funções da economia política. O Estado capaz de encaminhar esse processo histórico, realizar esse projeto de nação, levará seus habitantes ao bem comum. Ao refletir sobre fatores que impedem o desenvolvimento do que denomina por indústria, o autor chama a atenção para a ignorância e a opressão, capazes de diminuir o trabalho, a produção e progressivamente agravar a miséria da população. Assim, o texto de Estudos do bem comum ganha sequência 
de modo a deparar-se novamente com o problema de uma economia e de uma sociedade fundamentada no escravismo.

Já na terceira parte de Estudos do bem comum, no décimo quarto capítulo, intitulado Observações do Professor Malthus sobre a indústria, Silva Lisboa destaca a importância de toda nação em trazer para si o maior número de pessoas industriosas, menos ignorantes, conforme seu entendimento. Nesta ocasião, remete o leitor a uma nota de rodapé em tom mais panfletário que reflexivo, como se estivesse a assumir uma postura mais política e mesmo parlamentar. Em tal passagem, aproxima ao caso brasileiro a proposta que está a apresentar e defender.

Esta regra deve ser bem notada neste Reino, onde ainda tanta gente receia a importação de industriosos da Europa, que sabem fazer obras de indústria, que são desconhecidas, ou mui rudes no país, e que, pelo hábito de trabalho regular, atividade do espírito em perseverar nas empresas econômicas, e superior inteligência, são capazes de achar e multiplicar as produções úteis. Mais valem mil industriosos das Nações civis, que dez mil africanos; e todavia tão obstinadamente ainda se insiste na importação de bárbaros, de entendimento broncos, e braços repugnantes aos trabalhos necessários! (LISBOA, 1819, p. 329).

A partir de leituras que fez da obra de Thomas Malthus, autor por ele também tomado como autoridade em economia política, Silva Lisboa tece sua crítica à parca iniciativa de seu reino em trazer mão de obra ligada às atividades daquilo que chama de indústria. A aplicação de tal princípio se faz ainda mais necessária diante do particularismo brasileiro, ligado ao largo emprego da mão de obra escrava, cuja importação volta a criticar mais adiante. A ciência encaminha o rumo mais promissor, segundo o qual o fim do escravismo é uma necessidade, no entanto, impressiona o modo com que faz menção às pessoas provenientes da África, empregadas como mão de obra escrava no Brasil. Os então responsáveis por uma parcela incomensurável do trabalho realizado no Brasil, recebem por parte do autor adjetivações como bárbaros, broncos e repugnantes.

Aos olhos de leitores contemporâneos minimamente sensatos, repugnante é tal face do pensamento de Silva Lisboa a respeito de alguns aspectos da mão de obra escrava, quando não dos próprios escravos. Todavia, ao continuar a leitura do próprio Estudos do bem comum, no sexto capítulo da mesma terceira parte, voltado a estender análises sobre as causas do que classifica ser a indústria ativa e regular, em meio ao conjunto de causalidades abordadas o leitor se depara com nova e explícita defesa pelo fim da 
escravidão. Para Silva Lisboa, o escravismo não era um mal necessário, como por longo tempo ainda insistiriam muitos intelectuais e políticos brasileiros do século XIX. Refuta a ideia de que sem escravos não há colônia; tem por cegos aqueles que não reconhecem que a civilização demanda o fim do escravismo, e menciona de modo crítico o fato de que os mais fiéis chegam a atribuir tal progresso e melhora ao influxo da religião cristã (LISBOA, 1820, p. 25).

Já no décimo sétimo capítulo da terceira parte, cuja publicação se deu em 1820, tratado como Seção II de Estudos do bem comum, encontram-se rápidos comentários sobre os estudos de Thomas Malthus a respeito da questão populacional. Ali, Silva Lisboa reitera sua concepção de que o escravismo deve ser combatido, porque representa o polo oposto ao progresso. Desta vez, faz críticas à teoria de Malthus, e sugere ser o descompasso entre o crescimento populacional e o aumento da produção uma falha dos Estados, ou seja, das legislações criadas pelo homem. Embora reconheça a importância da obra de Malthus e sua grande circulação entre os interessados em economia política, afasta-se de suas concepções, porque identifica melhores respostas na esfera da moral, conforme a coerência interna de seu texto, onde os Estados foram tomados como entes morais.

... [Malthus] atribuindo às Leis da Natureza grande parte das misérias, que aliás evidentemente são as consequências necessárias de várias Leis desumanas, que tem organizado a propriedade de poucos, e a desgraça de inumeráveis, os quais são desanimados de ativa e regular indústria, pela quase física impossibilidade de melhora de condição; como são as Leis da escravatura, e das restrições da honesta circulação do trabalho, e do comércio legítimo, que muito tiram o interesse, e estreitam a esfera do trabalho produtivo (LISBOA, 1820, p. 63).

Tomado para análise o trecho citado acima, nota-se que a fim de justificar a crítica elaborada a uma das principais propostas de Malthus, Silva Lisboa refuta uma causalidade de ordem natural em favor de outra, de ordem cultural. Onde o autor inglês atribui razões naturais, Silva Lisboa entende ser um equívoco na orientação que as sociedades humanas impuseram às suas respectivas legislações. Ainda que de modo sutil, a citação acima corrobora com as observações realizadas até então, pois, mediante a cosmologia de Silva Lisboa, a ciência da economia política deveria ser encaminhada sem contradições com o que entendia ser aspectos ligados a ordem moral. Ficará ainda mais evidente tal preocupação nos capítulos seguintes do mesmo livro, quando se permite mais uma vez observar a influência que os conceitos aprendidos junto à filosofia natural 
exerciam sobre a cosmologia do autor, de modo a promover o que ele entendia ser uma lógica interna à sua obra e sobre a qual esta pesquisa busca lançar questionamentos, identificando seus limites explicativos.

No vigésimo e vigésimo primeiro capítulo, novamente os interesses são projetados ao exame das ideias de Malthus, agora acompanhadas daquelas formuladas por Humboldt, desta vez a respeito da influência da fertilidade das terras e do clima sobre a questão da indústria. A leitura e análise do que ali foi apresentado é muito sugestivo para a presente investigação. Embora o objeto abordado nesses capítulos seja o solo e o clima, Silva Lisboa projetou questões ligadas à filosofia natural àquela temática, esperando com isso alcançar o arranjo conceitual que deveria aproximar ciência e moral, além de terminar a discussão com o particularismo que fora tomado aqui como o mais pertinente para conhecer e analisar o caso da sociedade brasileira, o problema da escravidão.

Silva Lisboa identifica na análise oferecida por Malthus a ideia de que terras férteis e bom clima não favoreciam, de modo necessário, a indústria, riqueza e população; as facilidades proporcionadas pela presença de tais fatores levariam as respectivas populações a valorizar o que classifica de luxo do descanso em lugar do luxo do gozo, sendo que este último exige esforços mais sadios para corpo e mente. Lembra que Malthus apontava o aumento da população, a acumulação de capital, as invenções de poupar trabalho e a fertilidade das terras como fatores para o progresso da riqueza. No entanto, Silva Lisboa limitou-se apenas ao último deles, alegando ser o mais ligado à teoria geral da indústria, além de ter aplicação prática ao Brasil, dotado de terras férteis. Em última instância, embora reconheça a autoridade do pensador britânico, refutará a ideia de que as condições naturais favoráveis criariam hábitos de indolência na respectiva população (cf. LISBOA, 1820, p. 75 - 76).

Após mencionar os exemplos que Malthus foi buscar na obra de Humboldt, onde aquele havia encontrado larga descrição sobre as péssimas condições de vida ou mesmo a miséria em que grande parte da população se encontrava nas colônias espanholas, tal como o México, Silva Lisboa passa a discutir, apontar limites e mesmo tecer críticas ao que anteriormente apresentara. Inicia o texto destacando a filiação das análises econômicas de Malthus às regras de Newton, com o que afirma também estar em concordância. Sendo assim, apresenta ao leitor uma delas, A natureza nada faz debalde = ela é concorde consigo mesma. 
Em observância destas regras, não se deve atribuir à fertilidade das terras a inércia dos seus naturais, quando outras causas dão solução ao fenômeno; e é evidentemente contraditório dar a Natureza fertilidades às terras, e ao mesmo tempo dar torpor aos espíritos e corpos para não se aproveitar a sua dádiva (LISBOA, 1820, p. 76).

Feito o apelo literal, ainda que facilmente criticado, a um princípio geral da filosofia natural newtoniana, segue Silva Lisboa a discutir e refutar a proposta de Malthus, a atribuindo

... um paradoxo, que repugna a razão desprevenida; a irresistível evidência da Ordem Cosmológica; a justa Teoria das Causas Finais; e enfim ao senso comum de todos os indivíduos e Estados, que preferiram sempre os férteis, saudáveis, e geniais países, para cultura, compra, ou conquista, com os maiores sacrifícios de trabalho, tesouro e sangue. Nenhum conquistador preferiu a Arábia à Índia... (LISBOA, 1820, p. 78).

A se somar à argumentação acima, que passa pela ideia de razão, ordem cosmológica, causas finais e sobretudo ao senso comum, empregado enquanto o saber construído pela recorrência das relações estabelecidas entre os fatos, na esteira da filosofia de tradição anglófila, onde Silva Lisboa encontrara nomes como o de Smith, Malthus, David Hume, além do referencial epistemológico maior de Isaac Newton, todos por ele citados de modo literal ao longo da obra, o autor segue seus comentários sempre dirigidos às possibilidades de melhor aproveitamento de tudo o que a natureza possa oferecer, ou a superação diante das dificuldades de solo e clima com que outras nações venham a se deparar. Segundo seu entendimento, os esforços humanos, a partir de capacitações de sua própria natureza ${ }^{61}$, conferidas pela Providência, sempre serão suficientes para promover a indústria e o bem comum, conforme orientações da economia política.

Deste modo, conforme conclui a análise aqui proposta, em meio ao discurso de Silva Lisboa, a ciência da economia política deveria estar atenta aos desígnios de uma ordem moral, proveniente de sua religiosidade cristã, como é possível demonstrar a partir

\footnotetext{
${ }^{61}$ Coerente com a já mencionada ideia de natureza humana, Silva Lisboa admite que a natureza poderia influir no corpo físico e mesmo político, mas jamais alterar a constituição humana, de modo a amortizar o inato princípio do que denominava amor do gozo e da melhor condição de vida, tidos por ele como motores da indústria, causas necessárias para o progresso da civilização (cf. LISBOA, 1820, p. 77).
} 
das citações abaixo, nas quais de modo muito claro e direto o próprio autor o faz já nas primeiras considerações apresentadas em sua obra Princípios de Economia Política.

O mundo físico rege-se por leis simples e fecundas, que lhe dão ordem, harmonia, beleza e perpetuidade. Algumas daquelas leis são conhecidas pelos homens e segundo as mesmas leis regulam suas ações, previnem danos e adquirem muitos bens da vida. Reunidos em sociedade constituem um mundo moral, que parece também dever ser regido por leis de igual simplicidade e fecundidade, para viverem em paz e abastança. O conhecimento e o exercício destas leis é o que se chama ciência e prática de Economia que, segundo sua etimologia, significa a lei da casa.

A sábia Economia do Criador se manifesta claramente na infinita variedade com que diversificou as terras, climas e habilidades, dando a cada país e indivíduo suas produções, vantagens e aptidões particulares; evitando-se assim uma uniformidade desagradável e estabelecendo-se não menos uma dependência e aliança recíproca dos homens e Estados, para mutuamente se ajudarem e desfrutarem os dons da Providência (LISBOA, 1956, p. 112).

A filosofia natural que é compartilhada pela cosmologia de Silva Lisboa perpassa muitos dos títulos que compõem sua obra e modo recorrente estabelece as devidas relações entre a economia política e a moral religiosa, cuja orientação deveria estar refletida ao máximo nas próprias leis formuladas para organizar o Estado. Os conceitos encontrados junto à filosofia natural e tais relações eram determinantes para nortear suas leituras e análises projetadas sobre o caso da sociedade brasileira. Esta relação, concebida por uma cosmologia muito influenciada pela filosofia da natureza, permitiria garantir a razoável aplicação dos conceitos gerais de sua ciência ao caso particular do Brasil, a partir do que passava a estender suas críticas até o problema do escravismo, o qual surge cada vez mais como limitador da aplicação dos conceitos encontrados na cultura ilustrada, em especial na economia política.

Já no capítulo seguinte, mantém os comentários e críticas voltados às ideias malthusianas, em específico ao problema da fertilidade das terras como fator condicionante de um dado descanso, indolente e nada positivo, segundo a proposta de Malthus. Porém, à medida em que a apresentação e os comentários sugeridos por Silva Lisboa vão tomando corpo, a atenção do leitor mais uma vez é conduzida ao que está sendo destacado na presente ocasião, a questão da sociedade escravista. 
Mostra-se pois a todas as luzes, que a fertilidade das terras é a Mercê da Providência, que constitui o maior Patrimônio das Nações, que são com ela mais favorecidas; e, sem ela, todas as mais causas que influem no progresso da indústria e riqueza são, comparativamente, impotentes. Ao Céu pois, com mui especial razão devem com gratidão levantar as palmas os habitantes de tais terras, e podem com verdade, e religiosos êxtases, dizer - Deus nos doou este descanso. Este descanso porém, havendo facilidade de instrução, dá energia ao espírito para meditar nas Leis e Obras do Criador.

[...] Mas devo sempre dizer, que não poderemos regozijarmos de aclamar os campos bem-aventurados, senão quando a Divina Providência permitir, que a Agricultura se faça por braços livres (LISBOA, 1820, p. 86).

O descanso proporcionado pela fertilidade das terras brasileiras não iria, de modo necessário, conferir ao espírito de sua respectiva população a indolência que muitos estudiosos ainda viriam atribuir, embora já mergulhados nos séculos seguintes. Uma vez condicionado à instrução, ao contato e produção dos saberes, condição necessária e suficiente para que tal descanso ganhasse sua devida positividade, passaria então a servir não somente para a ampliação da riqueza nacional, como já apontado, mas também e sobretudo, segundo Silva Lisboa, às reflexões de cunho religioso. Entretanto, mais uma vez os brasileiros não estariam autorizados ao regozijo de tais benesses enquanto a nação convivesse com o emprego do trabalho escravo.

Os universais oferecidos pela ciência da economia política, que estariam a ruir diante da condição particular de uma sociedade escravista, segundo o autor teriam encontrado salvaguarda a partir da apropriação que Silva Lisboa fizera da filosofia natural dos modernos e seus conceitos de ordem universal, cuja importância é central na composição de sua cosmologia, e que por sua vez possibilitava submeter o caso particular do Brasil a uma dada concepção de processo histórico a ser percorrido também pelo progresso da riqueza brasileira. Cristianismo e ciência da economia política falam a partir de universais, a filosofia natural promove tal aproximação porque ela era tida então como a mais bem acabada literatura dos conceitos de caráter universal. A despeito dos limites que o instrumental da economia política poderia encontrar frente aos particularismos de casos em específico, e que muitas vezes levou o autor a recorrente silêncio acerca da própria sociedade em que vivia, uma leitura e análise mais minuciosa e pormenorizada foi capaz de destacar um instrumental teórico que capacitasse o autor a prolongar seus pareceres até 
mesmo sobre o caso da sociedade escravista então vivenciada pelo Brasil, e ainda segundo ele submetida à necessidade de transformações ao longo do processo histórico.

O poder generalizante do conceitual por ele utilizado deveria permanecer garantido, a despeito de situações particulares de sua nação. Se por um lado sentia-se mais confortável para discorrer sobre a humanidade, a natureza humana, o progresso e a civilização, por outro, ainda se via capaz de superar impasses com os quais se deparava quando a análise fosse dirigida a uma sociedade escravista. Dotado de uma visão geral de mundo em larga medida regida pela filosofia natural dos modernos, Silva Lisboa buscava aproximar ciência e moral religiosa, para assim se colocar ao estudo de caso que a ele mais interessava. Como identificado no início deste texto, através da relação entre a ciência da economia política e a moral religiosa, buscada através de um conceitual encontrado na filosofia natural, em Estudos do bem comum Silva Lisboa não só submeteu o problema do escravismo às suas críticas e sugeriu sua superação, como também demonstrou um olhar de certo modo positivo sobre o desenrolar da história do caso brasileiro e de sua respectiva sociedade.

Ainda acerca da característica escravista da sociedade brasileira, caberia registrar o olhar positivo que Silva Lisboa projetava para um futuro no qual a mão de obra livre estivesse na ordem do dia. A despeito de colocações que hoje devem ser vistas de modo lamentável e condenável a respeito da terminologia e mesmo de alguns dos conceitos com que abordava a temática, tinha claro para si que a escravidão era uma chaga a ser eliminada. A princípio cabe observar tal terminologia, com a qual esta pesquisa já se deparou, mas pode ser retomada neste momento a partir de outro trecho, mais uma vez encontrado em nota de rodapé, e novamente em tom mais parlamentar do que acadêmico. Ele se encontra no momento em que o autor refuta todas as justificativas utilizadas para defender o largo emprego da mão de obra escrava, indígena e africana, em colônias hispânicas, apontando suas consequências, sempre negativas.

Estes efeitos, a olhos vistos se manifestam em hórridos exemplos de crimes e atentados da população factícia africana. Foi fatal erro político constituir uma nação, na maior parte composta de gente que não nasce no país, e que não pode ser a ela afeiçoada, nem presa pelas cordas do coração. Estou certo, que, enquanto ela durar, o Brasil não pode ter a boa indústria de que é capaz. Portanto, desde já protesto, uma vez por todas, que a teoria da indústria, enquanto se aplica a este Reino do Brasil, pressupõe o seu progressivo desenvolvimento, desde a época em que, A 
Sabedoria do Governo, cessar o sistema de cativeiro (LISBOA, 1820, p. $44)$.

Se anteriormente fora destacado aqui adjetivações como bárbaros, broncos $e$ repugnantes, acima tem-se a expressão população factícia, destacada pelo próprio autor em itálico, somada à pretensa conclusão sobre a impossibilidade daquelas referidas pessoas em desenvolver afeto à nação. Ao longo de seus escritos, farto é o número de passagens com menções marcadas por esse espírito mais do que depreciativo e incapaz de projetar um olhar de caráter humanista ou humanitário. Embora tenha realizado o necessário registro, não é de interesse desta pesquisa aprofundar análise sobre tais pareceres, bem como tecer julgamentos sem a devida profundidade analítica que a temática merece e certamente receberá.

No momento, cabe ressaltar que o autor tem o fim da escravidão como condição necessária para o pleno emprego das orientações que a economia política teria a apresentar para o desenvolvimento e ampliação da riqueza nacional. Seu otimismo acerca da prosperidade do Brasil deveria passar por esse requisito de primeira ordem. É razoável concluir que projetou olhares mais positivos sobre sua nação, uma vez que a mesma já tivesse superado o escravismo. A relação entre a ciência da economia política e a moral de cunho religioso, forjada através de um farto e reconhecido leque de conceitos e termos oferecidos pela filosofia natural dos modernos, não somente permitiu Silva Lisboa refletir e discorrer a respeito de sua sociedade em particular, como também projetar um olhar positivo e otimista a respeito do desenvolvimento histórico de sua nação.

A filosofia da natureza por ele compartilhada fornecia à sua cosmologia elementos a partir dos quais relacionava ciência e moral religiosa. A partir dessa visão de mundo, buscava compreender aquela sociedade e interferir em seu respectivo processo histórico, cujo particularismo da escravidão, segundo o seu entendimento, não deveria continuar a comprometer a funcionalidade dos conceitos de ordem geral, a partir dos quais projetava suas análises. Justamente aí deparava-se com os paradoxos bastante difíceis de serem superados, quando então tangenciava o problema do escravismo ao longo de sua argumentação, permitindo notar que a aplicação dos conceitos sobre os quais se apoiava somente alcançaria plena viabilidade mediante o fim do modelo escravista. No entanto, o poder de generalização atribuído aos mesmos conceitos, somado à ideia de processo histórico, permitia a Silva Lisboa projetar aquele instrumental teórico e analítico também 
ao caso brasileiro, e tal generalização era pretensamente alcançada a partir de concepções encontradas junto à filosofia natural dos modernos, elementos centrais de sua cosmologia, por conseguinte determinantes na construção de sua obra. 


\section{Capítulo 4}

\section{A questão do desenvolvimento: \\ dos universais teóricos aos particulares do caso brasileiro}

Neste capítulo o intento que norteou os esforços dirigiu-se à cosmovisão expressa na obra de Silva com interesse voltado à pertinência dos elementos da filosofia natural junto à questão do desenvolvimento, ali tratada sob influência das ideias de Adam Smith. A partir do problema do desenvolvimento, por Adam Smith tratado como progresso da opulência das naçôes ${ }^{62}$, esta análise retomou o problema do escravismo desta vez relacionando-o à questão da disponibilidade de terras no Brasil. Sendo assim, a temática deste capítulo investigou na obra de Silva Lisboa o modo como o aparato conceitual influenciado pela filosofia natural, típico a uma visão de mundo de formação ilustrada, foi aplicado em sua obra com a pretensão de abordar o problema do desenvolvimento e suas relações com a problemática do escravismo e as questões da chamada teoria da fronteira aberta.

Embora o interesse pelo problema do escravismo tenha por fim retido maior parte das atenções e esforços de análise, o ponto de partida foi mesmo uma dada teoria do desenvolvimento apresentada por Adam Smith em A riqueza das nações, com destaque ao Livro III, intitulado Variações do progresso da opulência nas diferentes nações. A partir de elementos da temática ali apresentada, bem como as menções que a obra de Silva Lisboa faz à mesma, foi necessário a retomada do tema do escravismo, já tratado ao fim do capítulo anterior, desta vez submetendo-o a novos questionamentos e relacionando-o à concepção de fronteira aberta, para enfim alcançar alguma compreensão e análise acerca da importância dos elementos apreendidos junto à filosofia natural nas aproximações e

\footnotetext{
${ }^{62}$ Cf. SMITH, 1984, p. 225.
} 
distanciamentos entre os modelos teóricos adotados pelo autor e suas conclusões e propostas a respeito do desenvolvimento da riqueza na América portuguesa.

Sugestivo notar que tal temática, já abordada em Princípios de Economia Política, desta vez é retomada de modo mais extenso e direto, a partir da segunda e terceira parte de Estudos do Bem Comum, voltada aos princípios da economia política e cooperação social, onde já de início Silva Lisboa retoma paralelos entre da filosofia natural e sistemas sociais e econômicos, transmitindo a ideia de que a compreensão de ambos está de algum modo submetida a uma mesma ordenação lógica, o que se faz possível na medida em que, segundo seu entendimento, também é de certa forma uma ordenação natural.

Até no Sistema Planetário, os Astros tem movimento mais acelerado, ou retardado, em as respectivas órbitas, em proporção que variam em densidade e distância do Sol. Estas particularidades servem para escusar as anomalias que se encontram em países cultos, e de sábios Governos, que não podem de salto reformar antigas irregularidades da Economia política de seu país, pela prudente atenção à rudeza dos povos, e circunstâncias locais (LISBOA, 1819, p. 146).

Ainda no início da segunda parte, Silva Lisboa admite a existência de leis fundamentais do sistema social ou ordem civil, bem como uma harmonia entre as partes de um sistema regido por leis imutáveis, cuja identificação ou reconhecimento é o fundamento do conhecimento humano. A economia política, como apontado outrora nesta pesquisa, é a ciência responsável pelo exame dessas leis no que diz respeito ao sistema social, à ordem civil. No entanto, ainda que de modo sutil, Silva Lisboa reserva a participação do livre arbítrio humano diante do determinismo dessas mesmas leis, gerando deste modo violações responsáveis à prosperidade ou à miséria (cf. LISBOA, 1819, p. 148).

Após destacar os objetos de interesse da economia política, a existência de leis fundamentais, salvaguardar a presença e importância do livre arbítrio humano, segue o autor apresentando seus estudos acerca do bem comum, agora discorrendo sobre a fundamental lei econômica, de modo mais específico sobre a inteligência, esta desenvolvida a partir da cooperação; ambas enquanto diferencias responsáveis pela capacidade humana de superar sua própria fragilidade natural. Aponta então os atributos 
humanos $^{63}$, dados pelo Criador para que o homem torne mais produtivo o dom do entendimento, para então reunir toda a apresentação precedente em uma conclusão parcial que retoma o caráter pretensamente universal dos conceitos que adota, ao mesmo tempo em que antecede temas centrais da segunda parte de Estudos do Bem Comum: o trabalho e as fontes da riqueza das nações.

Cada pessoa pode ser testemunha e juiz da existência, e operação destes gerais atributos e instintos dos homens. E como se acham, mais ou menos, explícitos e ativos em todos os países, em proporção do progresso da civilização e inteligência, é incontestável, que são partes integrantes da Constituição Humana, e que o seu complexo entrou no Sistema Social, e Natural Lei Econômica (LISBOA, 1819, p. 154).

Por extensos parágrafos, Silva Lisboa se coloca a apontar os limites e mesmo os equívocos que identificou nos trabalhos ligados às escolas de pensamento que antecederam ao trabalho de Adam Smith, a exemplo do que outrora também fizera em Princípios de Economia Política. Ainda que não seja pertinente ao propósito desta pesquisa, cabe lembrar que tais apontamentos passam pelos fisiocratas, estendem-se em críticas às práticas protecionistas, com menções recorrentes à concepção por ele compartilhada de que a inteligência por si só não é capaz de gerar, ampliar ou mesmo bem administrar a riqueza de homens e nações, sem que se leve em conta o que entende ser a lei da sociabilidade, parte constituinte na natureza humana. Assim, não é equivocado afirmar que, segundo Silva Lisboa, o problema da economia política é também um problema de

\footnotetext{
${ }^{63}$ Segundo Silva Lisboa, para fazer com que o dote do Entendimento se tornasse mais produtivo, o Criador deu ao homem alguns atributos, listados aqui de modo mais coloquial: livre arbítrio de suas ações e ocupações; curiosidade em saber sobre o sucesso alcançado por seus semelhantes; desejo de gozo de bens terrestres; contínuo esforço para melhorar de condições; esperança na boa fortuna para vencer obstáculos; emulação para vencer competidores e rivais; confiança na própria capacidade; energia de indústria e apropriação do produto de seu próprio trabalho; repugnância ao trabalho mecânico; porfia em diminuir o trabalho escolhido através de instrumentos e maquinismos; timbre de independência de mercê alheia; ressentimento de injúria para resistir ao ofensor; impulso de sociabilidade para tratar com todos. Os tópicos passam sobretudo pelo indivíduo, pela competição, pela livre iniciativa e também pela propriedade. Ainda segundo o entendimento de Silva Lisboa, a listagem de tais atributos estaria fundamentada na observação e tais atributos estariam a compor a natureza humana.
} 
cunho moral, concepção que por sua vez está estreitamente ligada à obra de pensamento de autoria de Adam Smith ${ }^{64}$.

A questão do desenvolvimento surge de modo um tanto mais direto e explícito no momento em que Silva Lisboa aborda problema da divisão do trabalho. Aponta e critica os resultados negativos de possíveis abusos, tais como situações em que a divisão do trabalho é colocada de forma arbitrária, forçada e excessiva, contrariando intenções ou leis da natureza, mediante as quais a divisão pode se dar por sexo, por impulso conforme o gênio de cada indivíduo, além da influência de características particulares do local. Embora tenha evitado a citação de muitos exemplos, o que talvez o faça de modo premeditado a fim de não criticar sistemas e governos que ainda apoiava e junto aos quais ainda mantinha estreitos vínculos, Silva Lisboa aponta que são negativas divisões do trabalho tais como aquelas impostas pelas corporações de ofício, ou mesmo divisões impostas pela política econômica, o que a esta pesquisa chama a atenção por se colocar diretamente ligada à temática deste capítulo.

O Sistema Colonial (felizmente cessado no Brasil) dá outro exemplo de forçada divisão do trabalho: por isso as colônias da América não tem subido à riqueza possível. Ele obriga aos colonos a dirigir seus capitais e braços para a cultura das terras, impedindo o estabelecimento das manufaturas superiores, mal permitindo as artes inferiores, sem que não pode existir povoação civil. Naturalmente a agricultura é o principal emprego de colônias em países férteis e despovoados: mas é injusto obstar nelas ao natural progresso da indústria fabril (LISBOA, 1819, p. $320)$.

O emprego do termo naturalmente no final da citação acima é pertinente à presente análise. Ele faz menção direta à concepção de desenvolvimento concebida por Adam Smith e que por sua vez era compartilhada por Silva Lisboa. Mais do que isso, ao afirmar que a agricultura é a principal atividade em lugares de terras férteis e despovoados, nota-se mais uma vez a teoria de Adam Smith acerca do que se pode chamar de

\footnotetext{
${ }^{64}$ Terminando a introdução que antecede o direcionamento do texto à obra de Smith, Cláudio Napoleoni finaliza de modo esclarecedor um dos temas mais importantes na obra de Smith. O problema então era "fundamentar a possibilidade de uma reconsideração do problema político de Locke sem aceitar, contudo, qualquer sugestão racionalista, adotando, pois, a explicação humeana [elabora por David Hume] da moralidade. Para tal fim poder-se-iam explorar as possibilidades oferecidas pela atribuição de um papel socialmente positivo ao egoísmo: esta operação é o que caracteriza o pensamento de Smith" (cf. NAPOLEONI, 1985, p. 46).
} 
desenvolvimento ou progresso da riqueza das nações, bem como torna possível trazer à análise a questão da fronteira aberta, a partir da qual são estabelecidas as relações com o escravismo.

A se iniciar pela teoria de Adam Smith a respeito do desenvolvimento, de modo resumido, é possível notar as concepções de progresso natural e antinatural. No Livro III de A riqueza das nações, sob título Variações do progresso da opulência nas diferentes nações, encontra-se a divisão de tarefas entre campo e cidade, onde se produz o alimento e as manufaturas, respectivamente. Entre esses locais deve se dar o principal comércio de todas as sociedades civilizadas, com ganhos mútuos e recíprocos entre ambos, embora a subsistência da cidade seja derivada dos excedentes provenientes do campo. Assim, de modo natural, Adam Smith entende que o progresso das cidades deveria, sempre, suceder o melhoramento das condições de produção existentes no campo.

Os habitantes da cidade e os do campo são servos uns dos outros. A cidade é uma feira ou mercado permanente, à qual acorrem os habitantes do campo, que aí trocam a sua produção bruta por produtos manufaturados. É este comércio que fornece aos habitantes da cidade tanto as matérias-primas para o seu trabalho como os meios para a sua subsistência. Tanto o número dos empregados como a quantidade de subsistência disponíveis para os habitantes da cidade só podem pois aumentar na medida em que aumente a procura de produtos manufaturados por parte dos habitantes do campo; e essa procura só pode aumentar proporcionalmente ao progresso dos melhoramentos e do cultivo. Caso as instituições humanas não tivessem pois perturbado o curso natural das coisas, a riqueza e o crescimento das cidades dependeriam em todas as sociedades políticas do progresso dos melhoramentos e do cultivo da região ou do país em que essas cidades se situassem (SMITH, 1984, p. 229).

A seguir, Adam Smith salta para uma abordagem a respeito das colônias inglesas da América do Norte, onde nota nas cidades a ausência de manufaturas que abasteceriam terras distantes. Ali, o artífice prefere empregar qualquer excedente de capital na aquisição ou mesmo melhoramento das terras de cultivo em lugar de ampliar sua manufatura. Pode até passar de artífice a plantador, porque mesmo os salários elevados e as facilidades para a subsistência não o levariam a abrir de mão de trabalhar para si mesmo, ser seu próprio patrão, sem vínculos de dependência. Ali, a disponibilidade de terras a serem cultivadas torna o trabalho no campo mais atrativo. 
Em seguida, Adam Smith expõe suas concepções acerca dos países onde não mais haveria terras a cultivar, quando então os artífices dirigem seus esforços e capital para a produção e mesmo melhoramento de manufaturas a serem vendidas em outras regiões. Assim, termina o capítulo inicial do Livro III, capítulo intitulado Do progresso natural da opulência, finalmente tratando do comércio com o estrangeiro, cujo emprego do capital viria, se tomado o progresso ao modo natural, após o esgotamento das possibilidades de seu direcionamento ao cultivo das terras e à produção de manufaturas.

Se as coisas seguirem pois o seu curso natural, a maior parte do capital de uma sociedade em crescimento será primeiramente investida na agricultura, depois nas manufaturas, e em último lugar no comércio externo.

$[\ldots]$

Mas se bem que esta ordem natural das coisas tenha sido até certo ponto respeitada em todas as sociedades, foi em muitos aspectos completamente invertida em todos os Estados modernos da Europa. Foi o comércio com o estrangeiro que fez surgir em muitas cidades as manufaturas mais aperfeiçoadas, aptas para o fabrico de produtos vendáveis no estrangeiro; e as manufaturas e o comércio com o estrangeiro deram origem aos principais melhoramentos da agricultura (SMITH, 1984, p. 230).

Diante dessa teorização acerca do progresso da riqueza das nações, teriam os Estados modernos da Europa traçado uma trajetória antinatural, enquanto seria permitido conceber que as regiões colonizadas na América estariam a viver uma trajetória de desenvolvimento econômico de ordem natural. No entanto, nesta última região, a América, também havia a prática de algo condenado pela mesma teorização, pois ali encontrava-se o que Silva Lisboa chamara na última citação reproduzida acima de forçada divisão do trabalho. Tal divisão, ainda segundo o entendimento de Silva Lisboa, teria impedido as colônias de alcançar a riqueza que lhes era possível, obrigando colonos a dirigir esforços e capital ao cultivo das terras e impedindo as mais simples manufaturas. Daí a observação registrada entre parênteses desde o início da mesma citação em análise, quando menciona que, felizmente, o sistema colonial havia cessado no Brasil. Enfim, Silva Lisboa conclui o parágrafo lamentando injustiças que findavam impor obstáculos ao natural progresso da indústria fabril, mas não sem antes e mais uma vez reconhecer que naturalmente a agricultura deveria ser a principal atividade em colônias de terras férteis e despovoadas. 
Silva Lisboa critica os impedimentos impostos ao estabelecimento de manufaturas, embora reconheça ser natural primeiramente empregar esforços e capital junto à agricultura, diante da disponibilidade e fertilidade das terras, conforme o caso brasileiro. Em busca do que não está explícito no trecho em questão, mas é consideravelmente razoável inferir a partir de sua obra de um modo geral, Silva Lisboa concebia que as possibilidades do progresso na agricultura deveriam preceder $o$ direcionamento da riqueza à manufatura e mesmo ao comércio estrangeiro. Diante da proporção dessa mesma disponibilidade de terras tal como encontrava-se a situação do Brasil, o limite desse progresso a ser alcançado pela prática da agricultura seria algo incomensurável. Deste modo, na economia brasileira o trabalho seria voltado ao desenvolvimento a partir da agricultura, pois, retomando a teoria formulada e sugerida por Adam Smith, em terras americanas não haveria oferta de salário ou mesmo preço alcançado pela venda de manufaturas que compensasse a passagem da condição de agricultor, patrão de si mesmo, para a de artífice.

Reconhecida a condição de fronteira aberta, a maior questão colocada seria aquela relacionada ao emprego do trabalho escravo, condenado por Silva Lisboa de modo reiterado, conforme a teoria de Adam Smith por ele compartilhada. Sob tal orientação, a farta disponibilidade de terras férteis deveria ser explorada fazendo do Brasil um lugar especializado na agricultura. O progresso ou desenvolvimento das nações, tomadas de um modo geral, receberia uma maior e melhor participação da produção econômica brasileira na medida em que a atividade produtiva, a indústria ${ }^{65}$ desta região, estivesse voltada e especializada no cultivo de suas terras férteis, o que então havia ali de mais promissor. A partir da agricultura, a produção brasileira impulsionaria o aprimoramento de outras áreas do saber local, das técnicas, enfim, da própria indústria. Não sendo a indústria um termo exclusivamente ligado às manufaturas, promover a indústria nacional no Brasil seria promover a agricultura.

\footnotetext{
${ }^{65}$ Silva Lisboa inicia o capítulo advertindo acerca de mau usos do termo indústria. Cita Adam Smith, que muitas vezes utiliza o termo indústria para fazer menção à toda espécie de trabalho. Finalizando, Silva Lisboa informa que o termo deve ser aplicado a toda espécie de útil emprego de braços e capitais. Com razão se diz, indústria rural, mineira, fabril, mercantil, náutica, etc., para exprimir o trabalho empregado em quaisquer desses ramos. Todas essas espécies de indústrias, para serem produtivas, supõem no trabalhador graus de inteligência no objeto de suas respectivas operações. Silva Lisboa ensaia uma definição para o termo conforme ele esteve a empregá-lo na obra: "Indústria propriamente significa a energia do anima e constância dos homens nas tarefas da sociedade; isto é a diligencia e atividade de qualquer pessoa em adquirir os bens da vida, fazer alguma obra, ou prosseguir algum projeto, com intensidade e perseverança, ..." (cf. LISBOA, 1819, p. 261).
} 
Por ora no Brasil são prematuras os projetos de ativos especuladores, até intentando alguns, aliás bons servidores do Estado, fazer, por assim dizer, invasão de fábricas neste Continente, ainda tão despovoado e fértil. Só podem prosperar as Fábricas auxiliares da Agricultura, e da Marinha, que por ora devem ser (e não podem deixar de ser) os nossos principais Laboratórios e Oficinas de trabalhos produtivos, sendo sem efeito, (e só desvio de capital) todas as tentativas de precipitar com força as épocas de ulteriores melhoramentos, convindo, ainda por longo tempo, contentarmo-nos com as preciosas plantações nas margens das grandes costas e rios, e com as Minerações e Pastarias no interior (LISBOA, 1819 , p. 271).

Em extensa nota de rodapé que acompanha o trecho citado acima, com nova menção a Adam Smith, o termo indústria é retomado, desta vez relacionado ao progresso da civilização de um modo geral e não somente de uma dada nação em específico. Com isso, nota-se em Silva Lisboa um esforço em salvaguardar a importância de nações até então especializadas na agricultura, uma vez que também concebia tal atividade ligada ao progresso da indústria de modo geral, na medida em que a mesma fomentaria esforços para melhoramentos em outras áreas da economia e mesmo dos saberes e das técnicas, não somente locais, mas de todas as nações, visto que relacionados ao bem comum da civilização, senão da própria humanidade, através do livre comércio.

Se a produção agrícola deveria ser a maior responsável por inserir a economia brasileira da melhor forma neste comércio com as demais nações, tal concepção estava estreitamente ligada à importância que Silva Lisboa atribuía ao comércio com o estrangeiro.

Mas repito, e repetirei sempre: o Autor da Natureza variou os gênios e gostos dos indivíduos, para só fazerem bem, e apetecerem racionalmente, certas coisas, no evidente designo (quanto alcança a inteligência humana) de multiplicar as repartições da Tarefa Social, e os recíprocos suprimentos e gozos da vida, com prevenção de conflitos, que necessariamente resultarão de pretenderem várias pessoas objeto idêntico; igualmente, e ainda em maior razão, parece ter destinado a Geral Cooperação e Comunicação da Espécie Humana em todo o Globo, variando climas, terrenos, produtos, e outras vantagens locais, ao mesmo tempo segurando a suave dependência de todas as regiões. Nenhuma terra dá, nem pode dar, tudo. A adorável Providência fez tudo com sabedoria e harmonia: assim impossibilitou o avaro espírito de cobiça, e abarcamento de todos os ramos da indústria em um só Estado.

$[\ldots]$ 
As nações, porém, quanto são mais populosas, e industriosas, principalmente sendo marítimas, que (por assim dizer) são vizinhas a todo o Mundo, tanto menos podem considerar-se necessitadas, como os indivíduos, a abarcarem no respectivo território todos ou certos ramos da indústria, para que aliás os países estrangeiros tem melhores proporções, pelas suas vantagens naturais, ou adquiridas por antiguidade de estabelecimentos, hábitos, e gostos dos povos. Nestas Nações imenso números de indivíduos pode viver, e viver bem, sem ser do imediato produto do próprio trabalho, mas sim dos indizíveis variados produtos dos trabalhos dos povos dos mais distantes países com que comerciam. Aquela que tem mais extenso mercado geral, será a menos dependente de algum mercado particular de qualquer país, e em consequência o anual produto da sua terra e indústria, sendo livremente trocado pelos equivalentes estrangeiros, será da maior cópia, variedade, e perfeição, e por tanto será mais rica, próspera, poderosa, e acreditada em todas as gentes (LISBOA, 1819, p. 325).

Se nas duas primeiras citações deste capítulo foi identificada e analisada a presença de um conceitual tomado como universal, para assim proporcionar à economia política a capacidade de identificar sistemas cuja lógica de funcionamento poderia operar também de modo universal, a exemplo do que a ciência pretendia realizar junto à ordem natural, acima notamos o apelo ao credo e mesmo à moral religiosa segundo à concepção defendida por Silva Lisboa. O Autor da Natureza é o agente que dotou os homens da inteligência e propensão para a tarefa social; a Providência destinou os homens à Geral Cooperação e Comunicação da Espécie Humana em todo o Globo. De tal orquestração resultará o bem comum.

Na mesma citação acima mais uma vez é notória a importância atribuída por Silva Lisboa ao comércio entre as nações. A promover a cooperação entre a humanidade, o comércio entre as nações faria chegar a todos os lugares o que cada um deles fosse capaz de produzir melhor. E como já visto, o melhor a ser oferecido pelo Brasil seria sua produção agrícola, responsável pela melhor maneira de inserir tal região econômica em um circuito mundial de comércio. Abaixo, além de retomar a mesma temática, o instrumental de conceitos utilizados, tais como sistema, grande cadeia, equilíbrio, bem como e as metáforas empregadas, retiradas do mundo natural ou mesmo dos estudos em mecânica, novamente aponta a importância da generalização e mesmo a universalidade que Silva Lisboa atribuía aos conceitos como a responsável pela racionalidade e lógica que pretendia conferir a seu texto. 
... tirando qualquer enlace, se quebra a corrente, e perde o equilíbrio, com que se balanceava cada divisão do trabalho: tirado qualquer anel da Grande Cadeia Industrial, desfalecem, e até desaparecem, muitos outros. O sistema da ramificação dos trabalhos é muito sensível, e se assemelha ao sistema orgânico do vegetal muito comum no Brasil, a que os Naturalistas dão o título de planta sensitiva, cujas folhas eretas e vistosas caem em em todos os ramos com o mais leve toque de qualquer delas.

Por se não ter atendido, quanto cumpria, a esta observação, se vêm, em todos os Estados, Regulamentos, mais ou menos prejudiciais e absurdos, em que, destinando-se a Riqueza Nacional, ora sacrifica-se a Agricultura, isto é, a Indústria dos Campos, às Manufaturas e ao Comércio, isto é, à Indústria das Cidades, e ora, vice-versa, preferindo-se esta àquela; quando aliás uma não ode crescer e prosperar sem a outra, e a respectiva cooperação só pode ser bem sustentada, e progressiva, irmãmente dandose as mãos.

$[\ldots]$

Isto se verifica exatamente em cada Nação, que se pode considerar como imensa Fábrica ou Oficina de trabalhos do Campo, Cidade e Mar. Não se vendo assim, em espírito compreensivo, o Sistema Econômico, Nacional, e Social, não se pode a Espécie Humana ter a possível elevação da honesta indústria, opulência, e prosperidade (LISBOA, 1819, p. 342).

Todavia, como já apontado outrora por esta pesquisa, o largo emprego da mão de obra escrava em território brasileiro era uma das maiores dificuldades identificadas por Silva Lisboa para a aplicação do receituário daquilo que posteriormente viria a ser chamado de liberalismo, por ele compartilhado e amplamente empregado em suas análises sobre a economia local. A visão de que no Brasil o progresso e a opulência da riqueza nacional deveria se dar a partir da trajetória natural, sendo este termo empregado conforme o que fora concebido na obra de Adam Smith, para assim esgotar as possibilidades de se alcançar esse progresso a partir da atividade agrícola, antes de projetar maiores esforços e capital sobre as manufaturas em si, esbarrava em uma realidade escravista, por sua vez condenada pela mesma escola teórica que em larga medida orientava a produção intelectual de Silva Lisboa. Diante disso, como também já apontado outrora por esta pesquisa, a superação do escravismo era condição necessária para o pleno emprego da teoria junto às condições materiais da economia brasileira.

Daí, nota-se a dada condenação do escravismo praticada por Silva Lisboa em coerência com o instrumental teórico por ele adotado. $\mathrm{O}$ melhor proveito das possibilidades agrícolas brasileiras somente seria alcançado com o emprego da mão de obra livre. A farta disponibilidade de terras férteis deveria ser cultivada por homens livres e 
não por escravos, à despeito da situação histórica, da estrutura de produção encontrada na economia local, a qual deveria ser transformada. Tal situação, bem como a própria necessidade de superar o escravismo, não impedia uma perspectiva analítica que, segundo Silva Lisboa, estava conforme o que muitas vezes fora apresentado pela principal matriz teórica por ele adotada, a obra de Adam Smith, o que pretensamente se fazia possível devido à universalidade atribuída aos conceitos ali presentes. A universalidade atribuída aos conceitos, a se seguir o modelo da filosofia natural, deveria conferir a viabilidade de sua própria aplicação em situações históricas diversas. Sem tal conceitual, Silva Lisboa não seria capaz de colocar tais ideias no lugar em que pretendia vê-las aplicadas. Dentre outros fatores, as ideias não estavam fora do lugar porque o sujeito histórico que as utilizava as tinha como universais.

Adam Smith dedicou passagens de sua obra à reflexão acerca do trabalho escravo, quando então estabeleceu relações com a concepção hoje conhecida por fronteira aberta. De modo geral, ao longo da historiografia e estudos ligados a outras diversas áreas do conhecimento, tal concepção está estreitamente relacionada à questão do escravismo em recorrentes tentativas de analisar o emprego do trabalho escravo na América. Embora avesso a quaisquer justificativas, Adam Smith abordou essa relação entre a disponibilidade de terras e as formas de trabalho em passagens de sua obra, sem que a tenha tratado de modo exclusivo, com a ênfase que este trabalho historiográfico contemporâneo, de abordagem específica, gostaria de tê-lo encontrado. De modo mais franco e direto, Adam Smith e o que viria a ser a escola de pensamento liberal preocupou-se em criticar largamente o trabalho escravo, sendo a partir de tal esforço que algumas aproximações à temática da disponibilidade de terras se faz possível notar e submeter à análise.

Quando abordado pelo liberalismo o problema da escravidão gerou determinadas abordagens críticas a partir das quais encontra-se menções, ainda que indiretas, relacionadas à temática da fronteira aberta. De modo geral e introdutório, a questão é colocada ali da seguinte forma: a partir do aspecto jurídico, o trabalhador deveria possuir a força de trabalho como uma mercadoria, por sinal, sua única propriedade; tal mercadoria deveria ser livremente negociada, a exemplo de qualquer outra mercadoria, negociação regulada somente pelas leis do próprio mercado, resultantes da relação entre vendedores e compradores; diante da oferta de terras a serem cultivadas, por que razão um trabalhador livre iria vender seu trabalho por um valor menor do que aquele mesmo 
trabalho poderia produzir à margem de qualquer relação econômica e social praticada junto a um tradicional proprietário?

No entanto, qual seria essa situação imaginada, de que modo seria possível o trabalhador atuar, praticar o trabalho, e a partir dele produzir algum bem ao qual se atribui algum valor de mercado, sem a necessidade desse mesmo trabalhador se relacionar social e economicamente junto a um proprietário? Uma das possibilidades de resposta seria encontrada em situações históricas nas quais a agricultura ou a pecuária poderia ser praticada em terras que, teórica ou juridicamente, ainda não possuíssem seus respectivos proprietários, no sentido ocidental do termo. Colocado de outro modo, a oferta de trabalho, enquanto mercadoria a ser vendida, negociada, diminuirá de modo determinante em situações nas quais é ampla a disponibilidade de terras, ou seja, as situações de fronteira aberta.

Segundo João Manuel Cardoso de Mello, além de outros fatores de relevante importância tais como a alta lucratividade obtida como o tráfico negreiro, o trabalho compulsório, em especial o escravismo empregado na América de modo sistemático e em larga escala, fez parte do processo de desenvolvimento do próprio sistema capitalista ao promover a chamada acumulação primitiva.

... não é difícil compreender que somente haveria produção colonial se houvesse trabalho compulsório, servil (encomenda, mita, indutured, etc,) ou escravo.

O fundamental, no caso das "áreas vazias", é a abundância de terras apropriáveis. Não se trata, certamente, de um dado natural, mas da existência de terra farta para a produção, pelos colonos, da autosubsistência.

... Havendo abundância de terras apropriáveis, os colonos contariam com a possibilidade de produzirem a própria subsistência, transformando-se em pequenos proprietários e, especialmente, posseiros. Nestas condições, obter produção mercantil em larga escala significava assalariar a sua força de trabalho, o que exigia que a taxa de salários oferecida fosse suficientemente elevada para compensar, aos olhos dos colonos, a alternativa da auto-subsistência. Assim sendo, o trabalho compulsório era mais rentável que o emprego de trabalho assalariado (MELLO, 1987, p.39-40).

A se iniciar pela questão das possíveis formas de trabalho já experimentadas ao longo da história, no Capítulo II do Livro III de A Riqueza das Nações, Adam Smith trata 
das dificuldades de ampliação e melhoramentos do cultivo das terras na Europa medieval, situação na qual o autor identificou o emprego do trabalho compulsório, condenado sua eficácia de modo explícito e estendendo tal análise e conclusões também ao trabalho compulsório de tipo escravo.

Se se podia esperar poucas melhorias desses grandes proprietários, muito menos se podia esperar daqueles que ocupavam efetivamente a terra sob o comando deles. Nas antigas condições da Europa, os ocupantes de terras eram todos rendeiros e título precário. Todos ou quase todos eram escravos, embora sua escravatura fosse um tipo mais mitigado que a conhecida entre antigos gregos e romanos, ou mesmo em nossas colônias das Î́ndias Ocidentais.

$[\ldots]$

Ora, se raramente se pode esperar grandes melhorias da terra por parte dos grandes proprietários, muito menos se pode esperar quando eles empregam escravos como trabalhadores. Segundo acredito, a experiência de todas as épocas e nações demonstra que o trabalho executado por escravos, embora aparentemente custe apenas a própria manutenção dos escravos, ao final, é o mais caro de todos. Uma pessoa incapaz de adquirir propriedade não pode ter outro interesse senão comer o máximo e trabalhar o mínimo possível. Se algo ela fizer, além do suficiente para pagar a própria manutenção, só o fará se isso a beneficiar pessoalmente, sendo impossível obriga-la a fazer esse algo mais sob violência (SMITH, 1988, vol. II, p. 14).

A partir da obra do próprio Adam Smith nota-se com enorme clareza que a livre iniciativa, presente de modo geral dentre as ideias fundamentais do liberalismo, é contraditória às formas de trabalho compulsório, sobretudo se as comparações e análises entre trabalho livre e trabalho compulsório tiverem como ponto de partida o aspecto econômico, embora outros aspectos também sejam mencionados pelo autor, como é possível notar de imediato já no início da segunda das citações a seguir. Abaixo, ao modo típico da postura epistemológica da cultura ilustrada, encontram-se trechos retirados da obra de Adam Smith nos quais esse autor generaliza suas conclusões a respeito do trabalho escravo a partir da observação realizada sobre o caso particular da colonização da América Inglesa.

Assim sendo, julgo que se verifica na experiência de todas as épocas e países que o trabalho feito pelo homem livre se torna mais barato do que o realizado por escravos. É precisamente isto que acontece em Boston, Nova York e Filadélfia... (SMITH, 1984, p. 68). 
O orgulho do homem faz com que ele goste de dominar os outros, e nada o modifica tanto como ser obrigado a mostrar-se condescendente em persuadir seus subalternos. Sempre que a lei e a natureza do trabalho a executar o permitem, o homem geralmente preferirá o serviço de escravos ao de homens livres. As plantações de cana-de-açúcar e de tabaco podem permitir-se o emprego da dispendiosa mão de obra escrava. Ao contrário, o cultivo de trigo atualmente não pode. Nas colônias inglesas, nas quais o produto principal são cereais, a maior parte do trabalho é executada em sua maior parte por pessoas livres. A última resolução dos quacres na Pensilvânia, no sentido de liberar todos os seus escravos negros, pode convencer-nos de que seu número não pode ser muito elevado. Se os escravos representassem uma parcela considerável de seus empregados, nunca teriam concordado com essa resolução. Ao contrário, em nossas colônias açucareiras o trabalho todo é feito por escravos, e nas colônias produtoras de fumo uma parte muito grande é executada por escravos (SMITH, 1984, 70).

À primeira vista, tal conclusão é de considerável simplicidade teórica e conceitual, além de inserida de modo muito coerente aos princípios apresentados por um dos principais fundadores do liberalismo. Segundo o que está colocado acima, a análise de casos particulares, a partir das situações encontradas em Boston, Nova York e Filadélfia, demonstram e sustentam a tese geral, pretensamente universal, a-histórica, retomando e corroborando a síntese de que o escravismo é mais dispendioso do que o trabalho livre em todas as épocas e países, embora o mesmo autor reconheça que o orgulho humano seja responsável pela tendência à dominação quando a lei e as características do trabalho favoreçam o emprego da escravidão.

No entanto, ao se deter atenções à obra de pensamento dos liberais, aqui em especial à obra do mesmo Adam Smith, algumas proposições ali presentes podem parecer à primeira vista paradoxais, porque a contradição entre a livre iniciativa e o emprego da mão de obra escrava, bem como as vantagens econômicas da mão de obra assalariada não ficam tão explícitas, sendo possível por algumas vezes até mesmo observar que o autor chega a reconhecer, em situações históricas específicas, uma conjuntura na qual o emprego de formas de trabalho compulsório, em especial o trabalho escravo, parece ter sido uma imposição daquelas mesmas conjunturas.

Isso se faz possível notar em A Riqueza das Nações, no Capítulo VII, intitulado As colônias. Ali, a situação de fronteira aberta encontrada na América leva a análise a uma dada explicação para o emprego do trabalho escravo. Seria demasiado afirmar que tal 
explicação é um esforço de justificativa, ou mesmo a demonstração de uma necessidade econômica de se recorrer à prática da escravidão. O autor Henri Denis, em História do Pensamento Econômico, nota nessa postura de Adam Smith uma certa resignação. Ainda que por inferência, esse tipo de conclusão se faz possível a partir dos parágrafos iniciais da segunda parte do referido capítulo de A Riqueza das Nações.

Todo colonizador adquire terra em quantidade superior àquela que possivelmente tem condições de cultivar. Não tem que pagar renda da terra, e dificilmente há impostos a pagar. Não precisa repartir a produção com nenhum proprietário de terras, e o que paga ao soberano costuma ser uma ninharia. ... Por isso ela anseia conseguir mão de obra de toda parte e pagar-lhes os salários mais generosos. Todavia, esses salários generosos, associados à abundância e ao baixo preço das terras, logo levam esses trabalhadores a deixarem o serviço do patrão para se transformarem, também eles, em proprietários de terras...

Em outros países, a renda da terra e o lucro devoram os salários, e as duas classes superiores da produção oprimem a classe inferior. Ao contrário, nas novas colônias, o interesse das duas classes superiores as obriga a tratar a classe inferior com mais generosidade e humanidade, pelo menos onde a classe inferior não for composta de escravos (SMITH, 1988, p. 152).

A postura resignada que Henri Denis e outros pesquisadores atribuem à interpretação e análise elabora por Adam Smith acerca do emprego da mão de obra escrava nas colônias, pode ser identificada no modo como finaliza o trecho reproduzido acima: pelo menos onde a classe inferior não for composta por escravos. Conforme tal raciocínio, uma vez diante da possibilidade do emprego da mão de obra escrava, as classes superiores se vêm desobrigadas de um tratamento dotado de generosidade e humanidade junto à classe inferior.

Já nas páginas finais de Estudos do Bem Comum, Silva Lisboa praticamente reproduz essa passagem no Capítulo VI, Doutrina de Smith sobre as Causas e Prosperidade das Colônias, localizado no que chamou de Seção II, publicada em 1820, onde finaliza a terceira e última parte da obra. $\mathrm{O}$ autor resume a mesma relação entre a oferta de terras e o custo para se manter o cultivo a partir da mão de obra assalariada, diante da possibilidade desse mesmo agricultor preferir trabalhar para si mesmo nas terras ainda disponíveis. Ao fim, Silva Lisboa reproduz de modo quase literal o trecho no qual pesquisadores notaram uma dada resignação na postura analítica de Adam Smith: "Nas 
colônias, o interesse das ordens superiores determina um tratamento mais generoso e humano aos trabalhadores, ao menos onde não há escravos" (LISBOA, 1820, p. 29).

Em determinados momentos do texto como os mencionados acima, que de imediato podem parecer paradoxais, Adam Smith demonstra ao menos a preocupação em tecer algumas explicações para a coexistência de tais modelos em determinadas conjunturas da história, a livre iniciativa e o escravismo, por fim, sempre condenando a segunda e enaltecendo as vantagens da primeira para o progresso da riqueza nacional ${ }^{66}$. Algumas dessas passagens, nas quais Adam Smith se colocou a discorrer a respeito do progresso da riqueza nas colônias, foram tomadas por Silva Lisboa que as reproduziu de modo praticamente literal, no entanto, com um sutil e para ele determinante acréscimo de terminologia, a fim de destacar a importância da agricultura.

Os altos salários estimulam o aumento da população. ... O que estimula o aumento da população e do desenvolvimento estimula também o aumento da riqueza e da grandeza real (SMITH, 1988, p. 153).

Os altos salários animam a população. Ora tudo que anima a população e agricultura, anima a real grandeza e riqueza de qualquer país (LISBOA, 1820, p. 29).

Mais do que destacar a importância da agricultura para se alcançar o progresso da riqueza, sobretudo ao modo natural, Silva Lisboa nota que, segundo esse modelo do desenrolar da história econômica, tal progresso deveria contar com a supressão do trabalho escravo. Ao projetar a teoria geral sugerida pela obra de Adam Smith sobre o caso particular brasileiro, Silva Lisboa demonstra ter claro para si que ela somente traria o resultado esperado se o escravismo fosse superado. Crítico à intervenção dos governos e das leis para fomentar ou dificultar determinados setores da produção, seja a agricultura ou as manufaturas, e mesmo o comércio com o estrangeiro, bem como crítico ao emprego do trabalho escravo, passava então a defender o progresso da riqueza nacional a partir de uma trajetória natural, segundo a qual as condições naturais e a conjuntura histórica do Brasil, a exemplo do mundo colonial implantado na América de um modo geral, deveriam esgotar

${ }^{66}$ Tais argumentações, encontradas justamente nos momentos em que Adam Smith discorreu acerca da inviabilidade econômica do emprego da mão de obra escrava, viriam a compor o ideário e instrumental ideológico da causa abolicionista, tomada como condição necessária e suficiente para o advento do liberalismo, portanto, para o pleno exercício da livre iniciativa, que deveria ser exercida através do trabalho assalariado. 
as fartas possibilidades para o seu desenvolvimento agrícola. Todavia, para alcançar tal realização o autor se viu diante da necessária oposição ao trabalho escravo, que por sua vez era uma das principais engrenagens da estrutura de produção daquele mesmo universo colonial.

Junto à obra de Silva Lisboa nota-se de modo recorrente o leque desses supostos paradoxos cuja origem estava nessa intrincada relação entre a adoção do ideário liberal e a presença massiva e determinante do trabalho escravo na economia brasileira dos anos finais do século dezoito e início do século dezenove, uma das temporalidades históricas a se inserir a obra de Silva Lisboa. Como já apontado por esta pesquisa, a influência da economia política de Adam Smith e do liberalismo em geral levou suas análises a condenação ao escravismo. A escola liberal, ao defender o fim do escravismo em nome da livre iniciativa, do trabalho assalariado, do liberalismo, enfim, do sistema econômico posteriormente a ser denominado capitalismo, levou Silva Lisboa a buscar uma difícil conciliação entre os princípios teóricos por ele adotados e as suas atividades junto a uma elite econômica e política estreitamente ligada à propriedade da terra ou ao comércio, porém mergulhada no modelo escravista.

Em meio a tal contexto e motivado por tais intenções, a obra de Silva Lisboa não se limitou a criticar o trabalho escravo apenas a partir dos princípios adquiridos junto à economia política e ao pensamento liberal defendido na obra de Adam Smith. Fez somar a tal aprendizado outras formas de argumentação e apelo. Embora focado nos aspectos econômicos, ao elaborar Da liberdade do trabalho, Silva Lisboa inicia o breve texto retomando de modo muito claro e conciso a argumentação outrora utilizada de modo mais extenso em outros diversos textos e ocasiões. Assim, segundo suas concepções, é somente o trabalho livre aquele que levará aos benéficos efeitos que a indústria humana pode racionalmente desejar e conseguir. A liberdade em relação ao domínio de outrem ainda deverá estar acompanhada pelo livre arbítrio, a livre escolha, além de fatores como aptidão, talento e circunstância, condições para a realização de um bom resultado, alinhado às regras essenciais da justiça, convergente à riqueza particular e pública.

As condenações ao escravismo que Silva Lisboa retira da história têm como ponto de partida o livro do Genesis, passa pelas tribos que classifica de selvagens e mesmo canibais, para se alcançar então o espírito do cristianismo, onde por fim parece encontrar o mais forte apelo, embora paradoxal, contra o escravismo. 
Sei que repugna aos comuns sentimentos da humanidade, e ao espírito do cristianismo, que manda não fazer contra outro o que ninguém quer contra si; o que, posto as Divinas Escrituras, por amor da paz e subordinação, ordenassem a obediência dos senhores civis ou domésticos, quer bons, quer díscolos, e não proscrevessem explicitamente tão absurdo estabelecimento, complicado com mil vícios e abusos, que não se podem arrancar de salto, sem fazerem maiores males; todavia não é tal tolerância argumento, que justifique as barbaridades dos que a força, a fortuna, ou o erro elevaram sobre seus semelhantes (LISBOA, 1851, p. 91-98).

Apesar de as sagradas escrituras do universo cristão ordenarem obediência aos senhores, isso é feito em nome da paz e subordinação, mas não em nome da prática escravista em si. Assim, Silva Lisboa antecipa-se às críticas mais comuns, sem deixar de explicitar de modo antecipado o que parece ser também central em sua visão de mundo: a aproximação entre uma dada moral, sob orientação de sua religiosidade cristã e suas concepções acerca da natureza humana, sob explícita influência de uma dada leitura sob inspiração da cultura ilustrada. Tal confluência, coerente em sua visão de mundo e segundo a lógica interna que o mesmo autor pretendeu atribuir à sua obra de pensamento, o faz notar que o escravismo repugna aos comuns sentimentos da humanidade, e ao espírito do cristianismo.

A argumentação de Silva Lisboa não poderia deixar de fazer mais um apelo à autoridade de Adam Smith, novamente apontando que o trabalho livre é mais barato que o trabalho escravo ${ }^{67}$. Nesse momento, a universalidade atribuída aos conceitos de um liberalismo derivado da cultura ilustrada é condição necessária para justificar seu emprego em uma análise voltada em específico ao caso brasileiro; e Silva Lisboa demonstra ter clareza acerca da necessidade de que tal ideário, esse acervo de conceitos, fosse universal. Assim, antes de passar às menções que veio a fazer à obra de Smith, Silva Lisboa explicita a epistemologia e o modo como compreende e faz uso da análise desse filósofo escocês: $A$ experiência de todas as idades e nações mostra que a obra do homem livre vem, enfim de conta, mais barata ao mercado, do que a feita por escravo. A conclusão se deu a partir da experiência, e o que fora experimentado permite concluir o mesmo em diferentes épocas e

\footnotetext{
67 Os argumentos largamente utilizados pelos teóricos da economia política de cunho liberal foram sobretudo a da carestia do preço do escravo e a falta de motivação do escravo ao trabalho, o que gerava dificuldades de competitividade e até mesmo de inventividade, esta com a finalidade de melhorar a produção em si.
} 
diferentes culturas. Segundo entende Silva Lisboa, tendo por principal base a tese de Adam Smith, a obra do trabalho livre é, de modo universal, mais barata e mais eficaz que a obra do trabalho escravo.

A despeito de uma introdução ao tema que é toda ela voltada à argumentação de vertente moral, religiosa e iluminista, no texto em questão, Da liberdade do trabalho, Silva Lisboa novamente dirige seus esforços a uma análise de cunho econômico acerca dos resultados do escravismo. Dentre um variado leque de motivos econômicos apontados contra o emprego do trabalho escravo, incluindo a recorrente necessidade de apelo ao medo como forma de inibir rebeliões cuja sombra pairava no cotidiano do universo senhorio, rebeliões que por sua vez poderiam contar até com o fator agravante de no Brasil existirem verdadeiras nações de origem africana em meio a um número cada vez maior de escravos, Silva Lisboa dá proposital ênfase ao fato de que tal forma de trabalho afrouxa, se não estraga, os sagrados elementos da razão e da justiça.

Os pareceres apresentados acima, permitem dividir a presente análise em dois momentos de distintas temáticas, sendo a segunda mais ligada ao problema central desta pesquisa. Em primeiro lugar, tal situação de temor em relação às revoltas de escravos é recorrente nesses momentos consideravelmente tardios do período colonial brasileiro, pois já na virada do século dezoito para o século dezenove, se faz possível notar uma espécie de revigoramento da importância determinante da agricultura para a economia brasileira, o que fora acompanhado pela ampliação da demanda por mão de obra escrava. Contemporâneo a Silva Lisboa, tal período vivenciou nova expansão na produção agrícola, sobretudo aquela voltada à exportação, sendo o açúcar, o algodão e o café os elementos de maior destaque, cujo consumo encontrava-se sob crescente popularização no mercado europeu. Se o contexto externo vivia o processo de industrialização europeu, na América a ampliação da atividade agrícola seria acompanhada por revoltas como a ocorrida no Haiti, a partir de 1791, que marcariam o início dos movimentos de independência, também efeitos da crise geral do Antigo regime.

Em tal contexto, mais uma vez é possível notar a questão da fronteira aberta, bem como suas respectivas relações como o escravismo e seus respectivos críticos. Durante essa nova expansão agrícola, ganharam importância as chamadas florestas virgens, 
terras até então inexploradas nas imediações do Vale do Paraíba ${ }^{68}$, por exemplo, onde foram construídas fortunas econômicas com destacada relação principalmente junto ao tráfico de escravos ${ }^{69}$. A existência de tal fronteira aberta e a prática do escravismo continuava a demonstrar estreitas relações, seguindo o que já havia sido amplamente experimentado desde os primórdios do processo colonizador, processo histórico observado e analisado por Adam Smith e outros pensadores sobre as posses coloniais inglesas e portuguesas no Novo Mundo.

Em segundo lugar, ao afirmar que trabalho escravo afrouxa, se não estraga, os sagrados elementos da razão e da justiça, mais uma vez, o autor traz à tona um apelo à pretensa universalidade dos conceitos de origem tipicamente ilustrada, para defender a tese de que o resultado do trabalho de um homem escravizado jamais poderá competir em quantidade, perfeição e valor com o resultado do trabalho de um homem livre, porque o trabalho escravo não é condizente com os elementos da razão e da justiça.

No texto Da liberdade do trabalho, Silva Lisboa voltaria citar as análises que Adam Smith realizou a partir das colônias inglesas na América, onde esse último havia identificado explícita diferença entre regiões escravistas e não escravistas, sendo aquelas marcadas pela avareza e mesquinharia de senhores, verdadeiros responsáveis pela pouca iniciativa e criatividade notadas naquelas regiões, em grande medida dependentes do trabalho de seus escravos, assim como eram os romanos na Antiguidade. A pouca criatividade atribuída aos próprios escravos, pouco motivados a inventos ligados às facilidades e à própria melhoria do trabalho, ou o simples aumento de sua produção, como

\footnotetext{
${ }^{68}$ Cf. STANLEY, 1958.

69 "Os casos aqui citados não esgotam os exemplos das famílias que foram pioneiras na ocupação das terras do Vale do Paraíba fluminense e que conquistaram destaque político, econômico e social nas localidades onde constituíram fazendas. Além da primazia na ocupação de terras numa área de fronteira agrícola aberta, essas famílias tinham em comum um passado de migração portuguesa relativamente recente... Chama a atenção também o fato de que muitas das fortunas constituídas no rastro do café possuíam um capital previamente acumulado em outros setores bastante rentáveis como a mineração, o comércio de grosso trato e o tráfico de escravos..." (MUAZE, s/d, p. 314). Por sua vez, o historiador Fernando Novais afirma que, "paradoxalmente, é a partir do tráfico negreiro que se pode entender a escravidão africana colonial, e não o contrário" (NOVAIS, 1985, p. 105).
} 
assim se espera de homens livres, pode ser explicada em larga medida pela própria relação estabelecida junto a seus senhores.

\begin{abstract}
Quando algum escravo propusesse qualquer adiantamento deste gênero, o senhor seria inclinado a considerar a proposta, como sugestão à preguiça. $\mathrm{O}$ pobre escravo, em lugar de prêmio, muito provavelmente encontraria afrontas, e talvez castigo. Passava em provérbio serem os escravos preguiçosos e dorminhocos. Eles vendo passar quase todo o fruto do seu suor para a bolsa alheia, devem necessariamente preferir o - molles in gramine somnos [doces sonos na grama] - à ativa indústria, que lhes não dá proveito (LISBOA, 1851, p. 91-98).
\end{abstract}

No entanto, se a argumentação sob influência de Adam Smith parecia preocupada em não ultrapassar o apelo à experiência, dentro dos limites do que até então fora vivenciado pelas nações ao longo do tempo, submetendo tais observações ao escrutínio da razão, vale mencionar que Silva Lisboa o faz, pois embora não se prolongue em Da liberdade do trabalho, para esse luso-brasileiro os elementos da razão e da justiça possuíam sacralidade. Silva Lisboa era um intelectual ilustrado, um liberal, tal como reiteradas vezes fora destacado, mas é necessário tê-lo também como um moralista, e nesse sentido os aspectos cristãos e mesmo sua religiosidade católica a todo momento se fazem presentes em suas análises.

Não pode haver argumentos que invalidem esta verdade experimental; nem é lícito emudecer, e não repeli-los, sem ingrato desconhecimento dos desígnios do Criador. Os contra citados fatos se explicam por causas óbvias, que admira não serem todas nomeadas, antes algumas misteriosamente omitidas, por Escritores tão dignos de sua reputação, sendo as principais o - Abarcamento de Terras, o - Tráfico da Escravatura, o - Sistema Colonial (LISBOA, 1820, p. 79).

$\mathrm{Na}$ citação acima, Silva Lisboa inicia com a defesa de sua própria argumentação, cuja validade encontra-se sustentada pelo experimentalismo e por sua religiosidade, esta responsável por fazer conhecer as vontades e intenções do Criador, para segundo tais fundamentações terminar condenando o abarcamento de terras, o tráfico de escravos e o sistema colonial, pilares fundamentais da estrutura econômica brasileira que estava a analisar e refletir acerca de suas transformações. Mediante tais estruturas, mais 
uma vez Silva Lisboa recorre às análises oferecidas por sua matriz teórica, a economia política.

A respeito da extensão e política fundiária, é possível notar em recorrentes passagens de sua obra que Silva Lisboa as tem como uma das preocupações. Ao discorrer acerca das causas físicas e morais identificadas pelos economistas a respeito do progresso das nações, além de reservar importância para a atuação do Estado ${ }^{70}$, o autor trata sobre o problema da propriedade da terra.

Divisão das terras, proporcionada, mas não excessiva, sem obstáculo à aquisição por todas as classes, com o menor possível número de que se dizem, Bens Vinculados, Baldios, e de Mão-morta, quanto seja compatível com a Constituição do Estado (LISBOA, 1820, p. 13).

$[\ldots]$

A divisão das terras é a maior garantia da propriedade de todas as sortes. Ninguém pode ter segurança dos frutos de seus trabalhos, sem que as terras de uma Nação estejam no domínio particular, como se mostra pela experiência de todos os povos cultos (LISBOA, 1820, p 16).

Cabe destacar que, segundo o entendimento de Silva Lisboa e na esteira das teorias por ele compartilhadas, a propriedade particular da terra estava diretamente vinculada à propriedade de um modo geral, a toda propriedade que fosse resultado do trabalho. A ausência de tal situação, ou seja, a ausência da ideia de propriedade particular, seria a situação de um modo de vida selvagem, a se dizer a partir de sua própria terminologia, quando então estaria em vigência apenas a vontade do mais forte, sob o pretexto de que a terra, fonte primeira de tudo o que há, é comum dom da Natureza. Daí seu apelo argumentativo junto ao que é demonstrado pelo que vivenciaram todos os povos cultos.

Atento, Silva Lisboa antecipa-se e trata um exemplo histórico contrário à sua tese, projetada então sobre o caso da América. Cita os lacedônios, os espartanos, cujo Estado durou séculos sem a divisão de terras. Neste momento, Silva Lisboa mais uma vez

\footnotetext{
70 Mais do que proporcionar e garantir leis responsáveis pela garantia da segurança às pessoas e propriedades, Silva Lisboa entendia que o Estado também deveria ser o responsável por ordenar estabelecimentos e obras que não poderiam estar ao alcance, bem como não seriam do interesse particular as executar (cf. Lisboa, 1820,p. 13).
} 
condena a escravidão, permitindo concluir de modo razoável que, mediante a ausência da divisão de terras entre particulares o estado de selvageria fora evitado pelos espartanos através da prática do escravismo, o que estaria entre os motivos das revoluções e guerras frequentes (cf. LISBOA, 1820, p. 17). Deste modo, o autor novamente estabelece alguma relação entre a questão da terra e o escravismo.

Com tal encaminhamento das questões que se coloca a tratar, Silva Lisboa escreve a respeito das colônias da América recorrendo a exemplos de caso retirados até mesmo da Antiguidade Clássica, e assim segue construindo uma argumentação a partir de um instrumental teórico cuja aplicação não deveria ser determinada ou restrita a uma dada conjuntura histórica, um instrumental teórico que pretendia ser universal, baseado em resultados da experiência e observação, organizados em uma explicação de um modo geral ligada à matriz ilustrada, por sua vez somada a recorrentes apelos à moral de ordem religiosa. Nas análises que encerram Estudos do Bem Comum, Silva Lisboa destaca o problema do trabalho, estende-o à questão das terras para então tecer comparações entre situações vivenciadas na América.

\begin{abstract}
A Imunidade da Escravidão é das mais poderosas causas de adiantamento da indústria. Não se trata aqui do direito, mas do interesse. Os Soberanos dos mais cultos Estado da Europa já há séculos reconheceram ser do próprio interesse, bem entendido, não menos que do Bem-Comum dos povos, a abolição do cativeiro doméstico, e ainda da servidão de gleba, com que força os paisanos morar nas terras dos grandes senhores, para serviço de suas pessoas e herdades. ... os efeitos justificam a causa: só a cegueira a desconhece. Os pios tem atribuído a melhora aos influxos do Cristianismo. Por fatalidade, o que pareceu conveniente no Mundo antigo, se julgou impraticável no Mundo novo; e ainda hoje pelas más autoridades de Economistas interesseiros, que só olham ao presente, sem cura da posteridade, se crê por muita gente, aliás, judiciosa, que sem escravos não há colônias.

Não se tem olhado os sinais dos tempos, e nem ainda atendido ao grande fato, que está à vista da Terra, do quando comparativo da América Meridional com a Setentrional, onde se prepondera a população livre, e que por isso já tanto sobressai na indústria de todas as sortes. Não insisto neste melindroso assunto, que entra na província da Política; só protesto contra o apregoado absurdo, que no Brasil o sistema do cativeiro é um mal necessário (LISBOA, 1820, p. 25).
\end{abstract}

Ao tratar acerca do problema do desenvolvimento, com destaque à relação entre a disponibilidade de terras e o emprego da mão de obra escrava, Silva Lisboa faz 
recorrente apelo ao instrumental de análise e conceitos encontrados junto à economia política. A economia política de Adam Smith orienta sua análise. O deslocamento de uma mesma teoria pela diversidade de situações históricas que menciona e analisa ao longo do texto, em larga medida se fez possível pelo fato de Silva Lisboa atribuir a essa mesma teoria um caráter universal, e tal universalidade era por ele tida a partir de conceitos encontrados junto à filosofia natural. Uma dada concepção de natureza humana, a concepção de que a sociedade, bem como o universo econômico podem ser submetidos à ideia de sistemas, em larga medida regidos por leis que permitem conhecer o funcionamento, interferir e projetar transformações.

$\mathrm{Na}$ condição de princípios gerais, os fragmentos a seguir, localizados nas páginas finais de Estudos do Bem Comum, em larga medida retomam muitas outras colocações de semelhante sentido já apresentadas em sua extensa obra e mais uma vez autorizam a conclusão apresentada acima.

Escritores antigos e modernos tem declarado, indistintamente, contra os gozos da Sociedade, não reconhecendo, que o desejo dos confortos e cômodos da vida, e consequentemente da perfeição das artes, e melhora de condição, é o que continuamente alonga o homem civilizado...

... Não advertem, que também faltam a um dos primeiros deveres da religião, não admirando, nem agradecendo, a profusa liberdade da Mão Invisível do Autor da Natureza, que nos deu tantos órgãos de gozo, ... e tanto enriqueceu a terra de seus dons inefáveis...

Aí o Criador inspira inteligência para se descobrirem, e habilidade para se colherem, os mais úteis bens da vida, e dar-se-lhes as formas e transportes mais convenientes ao Bem Comum. Tudo pode em breve prosperar, não se obstando a entrada das luzes dos que estão adiantados na carreira da civilização (LISBOA, 1820, p. 57 - 58).

Mediante tal concepção, a ação divina, o Autor da Natureza, através da Mão Invisível, não só imprimiu à natureza humana desejos que conduz as sociedades ao aperfeiçoamento das artes e à melhoria de sua condição, portanto, ao desenvolvimento, como também tornou disponíveis as condições naturais para tal realização, que em última instância é o próprio bem comum, o progresso da civilização. A se seguir as linhas gerais dessa visão de mudo, o conhecimento possui importância central na promoção do bem comum, não somente a riqueza das ações, como o próprio conceito de desenvolvimento 
está diretamente atrelado àquelas tidas como as obras de referência do pensamento ocidental.

A classe dos homens de letras, especialmente dos verdadeiros amadores da Sabedoria, manifesta, por fixos e elevados princípios, exemplar emulação em prescindir dos mecanismos e baixos expedientes de obter fortuna, e só é ambiciosa em acumular cabedal de inteligência das Leis e Obras do Criador. Os Sócrates, Sólons, Locks, Newtons e outros Grandes Lumiares, que tem mais contribuído com seus escritos, e inventos, à boa ordem civil, e à riqueza das Nações não se distinguiram em materiais bens da vida, e menos em ostentação de riqueza (LISBOA, 1820, p. 70).

Pelo fato de formular e propor conceitos de ordem universal, assim como a religião concebe os desígnios do Autor da Natureza como universais, a filosofia natural opera na cosmovisão de Silva Lisboa como um instrumento para se compreender a ordem natural e suas transformações, mas sua concepção generalizadora e sua epistemologia também são projetadas na compreensão acerca das relações entre o homem, a sociedade, a própria natureza e também os governos ou o Estado, instrumentalizando a capacidade humana de intervenção e promovendo transformações rumo àquilo que concebia como desenvolvimento, sendo este último termo dotado de amplo significado, cuja abrangência transitava da riqueza material aos aspectos da moral religiosa, a compor uma cosmologia a partir da qual se colocava a observar, analisar e projetar intervenções da experiência humana no desenrolar de seu próprio processo histórico. 


\section{Considerações Finais}

José da Silva Lisboa foi contemporâneo a uma época de transição, marcada pela crise do Antigo Regime e também pelo final dos impérios coloniais modernos na América, período em que esteve inserida a independência política brasileira. Ainda jovem, deixou o Brasil, então a mais importante região colonial portuguesa, e dirigiu-se a Coimbra com a finalidade de ampliar sua formação. $\mathrm{O}$ ambiente universitário que lá iria encontrar estava em alguma medida transformado pela famigerada reforma universitária promovida nos anos sob governo do Marquês de Pombal. Ali, conforme o propósito do próprio governo português, passou por uma formação intelectual que deveria, sobretudo, ser revertida em melhorias na capacidade de produção e administração da riqueza gerada no universo colonial. Os saberes de vertente ilustrada adquiridos em Coimbra, ainda que sob especificidades de sua recepção pela cultura letrada portuguesa, como é possível notar, por exemplo, a partir da obra de Luís António Verney, proporcionaria a Silva Lisboa um instrumental teórico, metodológico e conceitual, cuja aproximação junto a temática e terminologia ligadas à filosofia natural, além de evidente, é de uso recorrente em toda sua obra.

Em meio à farta produção historiográfica acerca da obra de José da Silva Lisboa, esta pesquisa tomou como questão central a relação entre um dado ideário de cultura ilustrada e a obra de Silva Lisboa, temática cuja a necessária abordagem até então não fora realizada com a devida atenção. Assim, a proposta foi identificar e analisar a presença e a importância do que é possível, de modo geral, classificar como uma ciência iluminista, operando na construção de uma dada lógica interna, razoável e coerente que Silva Lisboa entendia estar conferindo à sua obra.

A filosofia natural dos modernos, em especial os pilares da filosofia natural de Isaac Newton, conceitos e epistemologia, ao modo que está sugerido em obras como as apresentadas por Ernest Cassirer, Thomas Hankins ou Paolo Casini, citados e comentados no início ou mesmo ao longo deste trabalho, fora apropriada por Silva Lisboa 
proporcionando-lhe uma cosmologia dotada de concepções tidas como de ordem universal, permitindo a este autor transitar entre condições históricas diversas. A partir da identificação e análise do que seria possível classificar como uma linguagem de segunda ordem a operar nas reflexões elaboradas por Silva Lisboa, em meio à vasta temática a respeito do ideário da cultura ilustrada ali presente, esta pesquisa interessou-se especialmente pelos elementos associados ao trabalho de Adam Smith. Deste modo, em larga medida as atenções estiveram voltadas a analisar a importância e as condições em que os conceitos e a epistemologia, encontrados na ciência iluminista, atuaram nos esforços de Silva Lisboa em submeter o caso brasileiro aos saberes da economia política formulada por Adam Smith.

As obras de Silva Lisboa analisadas aqui foram assim escolhidas por serem também aquelas nas quais foram identificadas maiores possibilidades de submeter tal material a leituras e análises, conforme o propósito e a metodologia empregada por esta pesquisa. São obras em que o autor fez menções, referências, citações, análises e críticas junto a um farto e diversificado leque de outras obras e autores, compondo desta forma um amplo cenário intelectual, um rico contexto linguístico a partir do qual foi possível melhor analisar não somente sua compreensão acerca das respectivas propostas, mas sobretudo suas intenções ao aplicar tal ideário nas mais variadas reflexões e projetos que elaborou a respeito do Brasil. Com notório destaque à obra Estudos do Bem Comum e conforme mencionado acima, os esforços estiveram voltados na identificação e análise acerca de uma espécie de linguagem de segunda ordem, concluindo que em tal linguagem atuavam de modo determinante muitos elementos provenientes da filosofia natural e seus então recorrentes apelos aos conceitos tidos como de ordem universal.

Se a extensão do balanço historiográfico que compõe o primeiro capítulo sobrepõe-se à profundidade em relação à análise de fontes históricas, tal momento por sua vez tornou possível notar com devida clareza o quanto a obra de Silva Lisboa fora submetida a interpretações que priorizaram ideologias e posicionamentos políticos de seus respectivos intérpretes, em detrimento do interesse conceitual ou mesmo uma compreensão mais pormenorizada acerca das ideias do autor, de um modo específico. Também pelo fato de ter se destacado como um dos introdutores do liberalismo entre a cultura letrada brasileira, Silva Lisboa e sua obra foram inúmeras vezes revisitados ao longo da história, dando origem a comentários elogiosos ou críticas vorazes, conforme o contexto e 
interesses do momento em que tais revisões foram elaboradas. Das conclusões a que chegou Nogueira de Paula aos comentários tecidos por Sérgio Buarque de Holanda, passando pela análise mais ponderada de Afonso Arinos, o qual já notara nos dois anteriores certos exageros a enaltecer ou rebaixar autor e obra, foi possível destacar a importância da problemática e da abordagem a que esta pesquisa submeteu a obra de Silva Lisboa, justificando melhor a pertinência do exercício de análise proposto aqui.

Ainda que dotada de interesse e implicações contemporâneos, esta pesquisa seguiu a reiterada recomendação de muitos estudiosos que se dedicaram à obra de Silva Lisboa em um passado um tanto mais recente, entre eles Fernando Novais, Jobson Arruda, Tereza Kirschner e Meira Monteiro, os quais apontam a promissora necessidade de lançar novos questionamentos à obra de Silva Lisboa. Ao se perguntar acerca dos elementos da filosofia natural na cosmologia que ali está expressa, esta pesquisa deparou-se com um autor erudito de múltiplos interesses, que pode sim ser tido como um conservador, mas cujo conservadorismo está expresso em uma obra de fôlego, a qual comporta amplo conhecimento a respeito de variados temas, a discorrer de modo complexo acerca de questões que vão da natureza humana às teorias econômicas, relacionando-os às suas concepções religiosas, de ordem moral e pessoal.

No segundo capítulo, essa relação entre religião e ciência iluminista recebeu algum tratamento, sobretudo destacando o fato de que, segundo Silva Lisboa, tais discursos não eram incoerentes. Naquele momento, foi possível concluir que o autor atribuía ao ideário iluminista notável complexidade. Silva Lisboa reconhecia que a Ilustração comportava ideias revolucionárias, interessadas em promover grandes rupturas com as estruturas do Antigo Regime, proposições das quais se afastava. No entanto, também identificava naquele mesmo contexto intelectual uma série de filósofos e ideias responsáveis por ampliar as luzes da razão, promover os saberes de ordem positiva, necessários ao progresso das nações e da própria humanidade, sem com isso recorrer a rupturas de ordem revolucionária. Deste modo, Silva Lisboa imprimiu à sua obra e à sua atuação intelectual e política uma postura vista como reacionária por muitos de seus estudiosos, ainda que por vias reformadoras, talvez mais tímidas, o mesmo autor também tivesse identificado e agido a partir da necessidade de ações transformadoras.

A partir de tais posicionamentos, Silva Lisboa afastava-se daquele primeiro propósito, mais ligado às grandes rupturas, e aproximava-se do segundo, assumindo 
posturas e atuações intelectuais e políticas interessadas em determinadas transformações, mas não em revoluções. Assim, durante as análises realizadas no segundo capítulo desta pesquisa, foi razoável concluir que seu afastamento em relação às sociedades maçônicas se deu porque era contrário às propostas revolucionárias, que em larga medida transitavam entre tais associações, contudo isso não significava o afastamento de um dado conjunto de saberes, os quais igualmente também transitavam ali. $\mathrm{O}$ dado afastamento não se dera de modo exclusivo por razão de sua fé cristã, de certo modo também atingida ali segundo suas concepções, mas comportava sobretudo as razões de sua aversão às propostas revolucionárias, muito presentes nos círculos da maçonaria brasileira, onde inúmeros membros tinham a superação do domínio exercido por Portugal como um dos problemas centrais.

Já a preservação de um dado alinhamento junto a considerável parte do ideário também compartilhado pelas mesmas sociedades maçônicas, se dera pelo fato que ali havia encontrado uma proposta transformadora, a ser efetuada a partir do conhecimento, dos saberes, rumo a uma positividade, um progresso, segundo a concepção e o interesse do autor. A fé cristã e a moral religiosa compartilhadas por Silva Lisboa estavam entre os principais elementos a partir dos quais ele condenava a revolução, enquanto a economia política deveria orientar uma transformação promissora em direção ao bem comum. Mais do que isso, o que chamou de constituição moral do cidadão deveria ser orientada pela aproximação entre os preceitos da religião e os saberes da economia política. Desta forma, a transformação pretendida por Silva Lisboa era por sua vez dotada também de muitos aspectos conservadores, o que é necessário reconhecer.

O hibridismo notado na cosmologia de Silva Lisboa, uma vez submetido ao problema que orientou este trabalho, permite avaliar a fundamental importância da filosofia natural na elaboração de sua obra. Neste exato ponto, a confluência entre a cultura religiosa e a cultura científica de vertente iluminista, reside a importância do trabalho de Isaac Newton, cuja repercussão e sobretudo as implicações ligadas a essa própria confluência era conhecida e citada por Silva Lisboa de modo reiterado. A partir das análises apresentadas no segundo e terceiro capítulos desta pesquisa, foi possível concluir com considerável clareza a respeito de tal importância dos conceitos, em larga medida de matriz newtoniana. Em tais capítulos foi possível concluir acerca da funcionalidade de tais teorias, conceitos e métodos, tomados como universais, operando nas análises e propostas 
que compõem a obra de Silva Lisboa, para quem tal instrumental garantia lógica interna, coerência e razoabilidade a muitas de suas reflexões, ainda que as mesmas fossem dirigidas a casos particulares.

A respeito dessa complexa cosmologia, formada por discursos de diferentes ordem e origem, mas segundo Silva Lisboa jamais contraditórios, também foi possível concluir que sua respectiva obra demonstra a complexidade com que se deu a chegada do liberalismo no Brasil. Tratou-se de uma ampla jornada ideológica, composta por variados aspectos, os quais transitaram da cultura religiosa à ciência iluminista, com amplos apelos de cunho moral, como notado no segundo e terceiro capítulos deste trabalho. No discurso de Silva Lisboa, moral religiosa, ciência natural, economia política eram fios de saberes e concepções a tecer a mesma trama do conhecimento, o qual por sua vez deveria orientar o progresso da riqueza e o bem comum, dentro e fora de sua respectiva nação. Assim, transitava do geral para o particular, acreditando estar sendo coerente ao aplicar suas concepções pretensamente universais aos estudos do caso brasileiro, este último imerso em suas especificidades.

Nessa direção, o terceiro capítulo esteve voltado a analisar a importância das relações entre moral religiosa, economia política e a ideia de bem comum sobre as concepções de Silva Lisboa acerca da formação da sociedade brasileira, bem como as transformações pelas quais aquela mesma sociedade deveria ser submetida, conforme o seu entendimento. Mais uma vez, notou-se que através de seus respectivos conceitos e métodos as teorias provenientes da filosofia natural promoviam a viabilidade de tais relações, possibilitando, segundo o autor, tecer pareceres a respeito do caso particular da sociedade brasileira. A moral religiosa e a economia política, tidas por ele como universais e não contraditórios, orientariam as ações para se alcançar o bem comum. Mediante tais concepções e instrumental, foi possível concluir que tal universalidade, o caráter e a eficácia das generalizações propostas na obra em questão, muitas vezes pretendiam estar sendo justificados a partir de um conceitual encontrado junto à filosofia natural, responsável pela articulação entre concepções e teorias diversas a operar em uma mesma cosmologia, bem como justificar sua aplicação em uma situação histórica em larga escala distante e diferenciada daquela onde tais teorias e visão de mundo foram elaboradas.

Já de início, as análises realizadas durante a elaboração do terceiro capítulo mais uma vez confirmaram a adoção de um paradigma de vertente newtoniana por parte de 
Silva Lisboa, pois os problemas analíticos sugeridos naquele momento da pesquisa tornaram possível identificar recorrentes menções ao empirismo de tradição britânica. Ainda no início daquele capítulo foi possível concluir não somente a relação entre o empirismo e os estudos da economia política, como também a relação entre a economia política e as concepções de Silva Lisboa acerca da moral, com destaque à sua postura antirrevolucionária. Crítico à Revolução Americana e à Revolução Francesa, Silva Lisboa não concebia a possibilidade de o bem comum ser alcançado a partir da grande revolta social. Ao se buscar a prosperidade pública, os saberes provenientes da economia política deveriam estar sob orientação da moral religiosa a que se alinhava o autor, jamais sob qualquer orientação de vertente revolucionária.

Ao tratar o caráter universal que Silva Lisboa atribuía aos conceitos por ele adotados a partir da economia política e da moral religiosa, concluiu-se acerca contradição entre o que o autor entendia ser um processo civilizatório e a formação da sociedade brasileira. Neste ponto, ficou mais uma vez destacada a importância dos conceitos retirados da filosofia natural, não somente nos esforços de aproximação entre a economia política e a moral religiosa, como também, e desta vez com maior destaque, nos esforços realizados pelo autor para a devida aplicação de seu instrumental teórico sobre o caso brasileiro, este marcado por uma sociedade de formação colonial escravista. Assim, destacaram-se dois conceitos que a filosofia natural dos modernos os tinha como universais: a ideia de natureza humana e o conceito de leis gerais. Tais conceitos encontram-se ali relacionados à proposta também pretensamente universal de humanidade, agora segundo a ótica do cristianismo, em especial a ideia de humanidade sujeita à condição do pecado original e passível de um processo universal de catequização e desenvolvimento. A partir de tais aproximações, tornava possível a Silva Lisboa aplicar as propostas da economia política ao caso brasileiro, ou melhor, ao processo histórico desempenhado pelo caso brasileiro.

A conclusão daquele terceiro capítulo tem como um dos pontos centrais o fato de que os particularismos podem ser tomados enquanto momentos de um processo histórico, o qual pode ser analisado a partir da aproximação entre uma ciência e uma moral que pretendem ser dotadas de aspectos e conceitos de ordem universal. Aquilo que nos estudos do caso particular não poderia ser submetido de modo imediato à análise e às soluções propostas a partir dos universais, passa então a ser tomado como parte de uma situação histórica em processo de transformação, esta por sua vez reformadora e jamais 
revolucionária. Transformação a ser orientada pelas análises da economia política e sob orientação da moral religiosa, cuja aproximação entre ambas e a aplicação das mesmas ao caso particular brasileiro acreditava ser possível a partir de conceitos universais, oferecidos em larga medida pela filosofia natural dos modernos então admitida, se não de modo consensual, ao menos de modo muito razoável pelo contexto intelectual a que Silva Lisboa se dirigia. Segundo o entendimento e a intenção do autor, isso conferia uma dada lógica interna a seus próprios textos, além de operar como um considerável recurso a torná-los mais razoáveis e convincentes a seus respectivos leitores, os quais compunham um cenário intelectual junto ao qual os saberes de ordem ilustrada e a moral religiosa poderiam exercer forte apelo.

A respeito da sociedade brasileira, conclui-se que sua respectiva formação, cuja característica marcante era a presença massiva e determinante de um incomensurável número de escravos, acabava impondo limites à aplicação das teorias adotadas por Silva Lisboa sobre a sociedade brasileira, a fim de que a essa última alcançasse um horizonte desenhado segundo o modelo de civilização ocidental. A partir da temática isolada para o terceiro capítulo, notou-se em Estudos do bem comum a classificação social que Silva Lisboa encontrara na obra de Adam Smith e segundo a qual seria possível compreender a capacidade produtiva, bem como a distribuição da riqueza gerada pelo trabalho. As três categorias ou ranks, conforme a denominação literal apresentada pelo próprio Adam Smith, deveriam ser os trabalhadores assalariados, os proprietários e os capitalistas; as classes características do que Silva Lisboa entendia ser uma sociedade civilizada, o horizonte por ele admitido como uma possibilidade a ser alcançada pela aproximação entre sua moral religiosa e a economia política.

Nessa trajetória rumo a tal modelo de civilização, o processo histórico a ser percorrido em direção ao desenvolvimento, temática que norteou as análises do quarto capítulo, deveria mirar uma determinada organização social submetida a tal divisão, mediante a qual também estariam distribuídas e cada vez mais especializadas as atividades de trabalho, tornando predominante a forma de produção capitalista, na esteira do pensamento econômico apresentado na obra de Adam Smith, principal norteador das análises de Silva Lisboa. Essa referida divisão de trabalho, em plena e explícita coerência com a sua principal matriz teórica, não comportava a forma de trabalho escravo, como aqui já afirmado por reiteradas vezes. 
Desta forma, o quarto e último capítulo a encerrar esta pesquisa foi aquele em que mais buscou-se cotejar aproximações e distanciamentos entre a cosmologia científica presente na obra de Silva Lisboa e as propostas de Adam Smith. O problema que norteou essa aferição foi a questão do desenvolvimento, a prosperidade ou progresso da riqueza das nações, a dizer ao modo dos referidos autores. Mais uma vez as análises tornaram imprescindível a tarefa de abordar as concepções de Silva Lisboa acerca da então condição escravista da economia brasileira, desta vez somada ao problema da estrutura fundiária, cuja relação entre ambas aqui se fez a partir da problemática estabelecida pela teoria da fronteira aberta.

Novamente foi possível destacar na cosmologia de Silva Lisboa a importância epistemológica que tal autor atribuía ao conceito de leis gerais, a operar no movimento dos astros celestes, como também no sistema social, sendo a economia política a ciência responsável pela compreensão desta última. Concluiu-se acerca da considerável influência que a obra de Adam Smith exerceu sobre as análises e propostas oferecidas por Silva Lisboa, na medida em que este último, seguindo as propostas daquele, atribuía à inteligência, à cooperação e sobretudo ao trabalho, a principal fonte da riqueza de qualquer nação. A partir desse ponto inicial, a análise do quarto capítulo seguiu estabelecendo aproximações e distanciamentos entre as concepções de Silva Lisboa e as diversas escolas de pensamento econômico que precederam ou mesmo dividiram o contexto histórico ligado à própria economia política de Adam Smith.

Deste modo, o problema do desenvolvimento conduziu a presente análise não somente às aproximações junto à obra do próprio Adam Smith, mas também à conclusão de que Silva Lisboa tivera larga compreensão a respeito das propostas do que viria a ser chamado de liberalismo econômico, em especial a respeito das concepções de Adam Smith acerca da divisão do trabalho. Neste ponto concluiu-se que Silva Lisboa tomou o instrumental teórico oferecido pela obra de Adam Smith para, a partir do mesmo, projetar críticas que poderiam ser divididas em ao menos duas frentes de destaque: a crítica às imposições sofridas pelo Brasil ao longo da história, mediante sua condição colonial, o que impedia a livre atuação em qualquer área de produção; bem como a crítica à divisão entre trabalho livre e trabalho compulsório, sendo a escravidão o exemplo mais relevante às preocupações de Silva Lisboa. 
As principais conclusões do último capítulo se deram justamente a partir da estreita relação entre o problema do desenvolvimento e o problema da divisão do trabalho, conforme identificada por Silva Lisboa na obra de Adam Smith. Sendo assim, o desenvolvimento da economia brasileira, a exemplo do que ocorrera ou ainda ocorria em muitas regiões coloniais da América, estaria sendo um desenvolvimento natural, pois as potencialidades do campo, a partir da agricultura, estariam sendo ali exploradas antes do desenvolvimento das cidades e suas respectivas manufaturas, e sobretudo antes do desenvolvimento do comércio de um modo geral, o qual deveria suceder aos dois primeiros, conforme observado por Silva Lisboa, à luz das concepções teóricas de Adam Smith.

Nas análises acerca de tal desenvolvimento natural do progresso, conforme o desenrolar da história econômica vivida na América, estaria sendo identificada alguma explicação para o emprego da forma de mão de obra escrava, cuja necessidade se fazia presente diante da disponibilidade de terras cultiváveis. No entanto, Silva Lisboa mais uma vez demonstra muito razoável compreensão da obra de Adam Smith ao defender a necessidade de se colocar fim ao trabalho escravo para somente assim, de modo mais razoável e promissor, se explorar a mesma disponibilidade de terras referida acima. $\mathrm{O}$ desenvolvimento segundo o modelo natural, conforme apresentado por Adam Smith, deveria ser alcançado ao se buscar, a partir do trabalho livre, a máxima exploração da potencialidade agrícola brasileira.

Assim, segundo seu entendimento acerca das condições do desenvolvimento econômico local, se por um lado as manufaturas não deveriam sofrer impedimentos, por outro as potencialidades agrícolas eram de fato tidas como mais promissoras. Uma vez tecidas tais considerações, a despeito dos impedimentos ou do apoio às manufaturas, bem como a destacada prosperidade anunciada pela disponibilidade de terras cultiváveis, conclui-se que o emprego da mão de obra escrava era para Silva Lisboa o fator menos condizente com o modelo de desenvolvimento por ele adotado; a trajetória rumo ao progresso da nação deveria ser percorrida a partir do emprego da mão de obra livre, condição necessária para outro preceito fundamental daquela teoria econômica, a livre negociação do trabalho.

Tomado por aquele que parece ter sido o mais destacado paradoxo entre seu instrumental teórico e a realidade histórica que o cercava, mais uma vez foi possível notar 
os esforços de Silva Lisboa ao projetar os princípios da economia política ao problema do desenvolvimento econômico brasileiro. Diante do paradoxo entre a livre negociação, que por sua vez deveria ser aplicada também ao universo do trabalho, e o largo emprego da mão de obra escrava no Brasil, buscava coerência entre os princípios teóricos que adotara como norteadores do desenvolvimento e a realidade material brasileira que se impunha diante de suas observações e análises.

Sob tal interesse, além de permitir a identificação e análise das recorrentes críticas tecidas por Silva Lisboa ao emprego da mão de obra escrava de um modo geral, por vezes mencionando o caso brasileiro em particular, esta pesquisa possibilitou notar que o esforço analítico de Silva Lisboa acrescentara às condições necessárias ao bom desenvolvimento da economia, não somente o trabalho livre, mas também a ampliação do número de propriedades fundiárias. Coerente com os pilares fundamentais da ideologia a que se alinhara, tal autor demonstra ter muito bem compreendido que o desenvolvimento econômico projetado pela mesma deveria se dar a partir do indivíduo livre, da propriedade particular ou privada e da livre iniciativa.

A partir dessa mesma perspectiva teórica proveniente da obra de Adam Smith, Silva Lisboa passa pelo tema do comércio exterior. Sua prática seria um dos fatores determinantes para se potencializar a riqueza das nações, a qual deveria estar diretamente associada ao conceito de renda per capita. Quanto maior a renda ou produto per capita, mais rico seria o país, e esta renda deveria ser ampliada a partir da divisão e especialização do trabalho, fatores determinantes para o aumento progressivo da produtividade. Ainda segundo Adam Smith, a divisão do trabalho seria causa e efeito da expansão do mercado, o qual seria cada vez mais ampliado na medida em que ampliado fosse o número de nações nele envolvido através do livre comércio. O livre comércio entre as nações transformaria o mundo todo em um só grande mercado, no qual as nações melhor participariam a partir do que melhor fossem capazes de produzir a partir do trabalho, e no caso brasileiro a melhor participação deveria ser a partir da agricultura. Desta forma, todas as nações atingiriam o desenvolvimento e a riqueza ao longo do processo histórico de expansão do comércio exterior.

Conclui-se assim que o conceitual proveniente da filosofia natural a compor sua cosmologia, tenha sido um dos mais importantes recursos intelectuais e mesmo discursivos para que Silva Lisboa colocasse tais ideias, as ideias liberais, no lugar em que 
pretendia vê-las aplicadas. Tal instrumental teórico foi imprescindível para se tentar evitar que aquelas ideias não estivessem fora do lugar, afinal, o sujeito histórico que as utilizava as tinha como universais. O capitalismo, embora ainda historicamente recente e talvez ainda não reconhecido como tal, já pretendia-se universal; e as ideias liberais, o liberalismo, sua principal referência ideológica, já era versátil mais que o suficiente para apresenta-lo enquanto modelo igualmente universal, a ser adotado por todas as nações em seus projetos de desenvolvimento. Foi essa cosmologia científica o objeto de análise desta tese, e a partir de tal interesse acredita-se ter sido possível ampliar não somente a compreensão de mais um importante aspecto da vasta obra de Silva Lisboa, como também sua respectiva importância na chegada das ideias de Adam Smith e do liberalismo na cultura letrada e nos projetos de desenvolvimento histórico do Brasil. 


\section{Bibliografia}

ABBAGnANO, N. Dicionário de Filosofia. São Paulo: Martins Fontes, 2000.

ABRANTES, Paulo. Imagens de natureza, Imagens de Ciência. Campinas-S.P.: Papirus Editora, 1998.

ACIOLI, Gustavo. A Ascensão do Primo Pobre: o tabaco na economia colonial da América Portuguesa. Um Balanço Historiográfico. IN.: Saculum - REVISTA DE HISTÓRIA [12]. João Pessoa, jan./ jun. 2005.

ALEXANDRE, Valentin. Os sentidos do império. Questão Nacional e questão colonial na crise do Antigo Regime português. Porto: Afrontamento, 1993.

ALFONSO-GOLDFARB, Ana Maria; BELTRAN, Maria Helena (orgs). Escrevendo a história da ciência: tendências, propostas e discussões historiográficas. São Paulo: EDUC, 2004.

ALMEIDA, José (org.); LISBOA, José da Silva. Estudos do Bem Comum e economia política. Brasília: IPEA, 1975.

AMARAL, Braz do. Comemoração do Centenário da morte de José da Silva Lisboa. IN: Revista do Instituto Histórico e Geográfico Brasileiro, (170): 194-316, 1935.

AMZALAK, Moses Bensabat. Do Estudo e da Evolução das Doutrinas Econômicas em Portugal. Lisboa, 1928.

ALMODOVAR, Antonio. Processos de difusão e institucionalização econômica política no Brasil. IN: CARDOSO, José Luis (org.). A economia política e os dilemas do Império-brasileiro (1790 - 1822). Lisboa: Comissão para comemorações dos Descobrimentos Portugueses, 2001. 
ARAÚJO, Ana Cristina. A Cultura das Luzes em Portugal: temas e problemas. Lisboa: Livros Horizonte, 2003.

ARRUDA, J. J.; NOVAIS, F. Prometeus e Atlantes na forja da nação. IN: Economia $e$ Sociedade. Campinas, v. 12, $\mathrm{n}^{\mathrm{o}} 2$ (21), p. 225-243, jul./dez. 2003. Publicado originalmente em Lisboa, José da Silva (Visconde de Cairu). Observações sobre a franqueza da indústria, e estabelecimento de fábricas no Brazil, Brasília: Senado Federal, 1999. (Coleção Biblioteca Básica Brasileira).

ARAÚJO, Ana Cristina. A Cultura das Luzes em Portugal: temas e problemas. Lisboa: Livros Horizonte, 2003.

AUSTIN, J. L. How to do things with words. Oxford: Oxford University Press, 1975 [1962].

BARATA, A. M. Luzes e Sombras: A ação da maçonaria brasileira (1870 - 1910). Campinas: Editora da Unicamp, Centro de Memória - Unicamp, 1999. Maçonaria, sociabilidade ilustrada e independência do Brasil 1790 - 1822. Juiz de Fora: UFJF; São Paulo: Annablume, 2006.

BARROS, Roque Spencer Maciel. A ilustração brasileira e a ideia de universidade. São Paulo: Editora da Universidade de São Paulo, 1986. $1^{\text {a }}$ edição: 1959.

BELCHIOR, Elysio de Oliveira. Visconde de Cairu: Sua Vida e Obra. Rio de Janeiro: Confederação Nacional do Comércio de Administração Nacional do Senac, 1959.

BEZERRA, José Augusto/ Schwamborn, Ingrid (orgs.): Joseph Haydn na Corte Real do Rio de Janeiro (1816-1822), Fortaleza: Editora UFC, 2010.

BOBBIO, N.; MATEUCCI, N.; PASQUINO, G. Dicionário de Política. Brasília: Editora da Universidade de Brasília; São Paulo: Imprensa Oficial do Estado, 2000.

BOTO, Carlota. Iluminismo e Educação em Portugal: o legado do século XVIII ao XIX. Petrópolis: Vozes, 2004.

BURKE, Peter. Uma História Social do Conhecimento: de Gutenberg a Diderot. Rio de Janeiro: Jorge Zahar Ed., 2003. 
BURNS, E. Bradford. The role of Azeredo Coutinho in the Enlightenment of Brazil. Hispanic American Historical Review 44 (May 1964), 145-160.

BURTT, Edwin A. As bases metafísicas da ciência moderna. Brasília: Editora da Universidade de Brasília, 1991.

BUTTERFIELD, Hebert. As origens da Ciência Moderna. Lisboa: EDIÇÕES 70. $1^{\mathrm{a}}$ edição em inglês: The Origins of Modern Science, de 1949.

CABRAL, Alfredo do Valle. Vida e Escriptos de José da Silva Lisboa (1881). IN: Cairu, org. E. Vilhena de Morais. Rio de Janeiro, 1958.

CAEIRO, Francisco da Gama. Para uma história do iluminismo no Brasil: notas acerca da presença de Verney na cultura brasileira. Rev. da Fac. de Educ., São Paulo, 1979.

CALAFATE, Pedro. A idéia de natureza no século XVII em Portugal. Lisboa: Imprensa Nacional-Casa da Moeda, 1994.

História do Pensamento Filosófico Português. Lisboa: Editorial Caminho, 2001.

CALDEIRA, Jorge (org.). José Bonifácio de Andrada e Silva. São Paulo: Editora 34, 2002. (Coleção Formadores do Brasil).

CARDOSO, J. L.. A história natural, o império luso-brasileiro e a economia política na obra de Domingos Vandelli. IN: Anais do V Congresso Brasileiro de História Econômica e $6^{a}$ Conferência Internacional de História de Empresas. Caxambu, Minas Gerais, 2003.

CARNEIRO, A. e Simões, A. (2000). Enlighthtenment science in Portugal: the estrangeirados and their communicating networks. IN: Social Studies of Science, $2000 ; 30 / 4,591-619$.

CARRATO, J. F. Igreja, Iluminismo e Escolas Mineiras Coloniais. São Paulo: Cia. Editorial Nacional e Editora da Universidade de São Paulo, 1968.

CARVALHO, Darcy. Desenvolvimento e livre-comércio: as ideias econômicas e sociais de Visconde de Cairu. São Paulo: Instituto de Pesquisas Econômicas, 1985. 
CARVAlHO, J. M. A construção da ordem. A elite política imperial. Rio de Janeiro: Delume Dumará, 1996.

. História intelectual no Brasil: a retórica como chave de leitura. In: Topoi.

CARVALHO, L. R. As Reformas pombalinas da instrução pública. São Paulo: Edusp/Saraiva, 1978.

CARVAlHO, Rômulo. A Física Experimental em Portugal no Século XVIII. Lisboa: Instituto de Cultura e Língua Portuguesa, 1982. . A história natural em Portugal no século XVIII. Lisboa, I.C.L.P., 1987. . Coletânea de Estudos Históricos (1953-1994). Univ. de Évora, 1997.

CASINI, Paolo. Newton e a consciência européia. São Paulo: Editora da Universidade Estadual Paulista, 1995.

CASSIRER, E. Antropologia Filosofica. Introducción a una Filosofia de la Cultura. México - Buenos Aires: Fondo de Cultura Económica, 1951. . A filosofia do iluminismo. Campinas: Unicamp, 1994.

CHIARAMONTE, Jose Carlos. Pensamiento de la ilustracion. Caracas : Ayacucho, 1979. . La Ilustracion Hispanoamericana. Venezuela, 1976.

CIDADE, Hernani. Lições e Cultura e Literatura Portuguesas. 2 volumes. Coimbra: Editora Limitada, 1975.

COGGIOLA, O (Org.). A Revolução Francesa e seu Impacto na América Latina. São Paulo: Nova Stella: Editora da Universidade de São Paulo; Brasília, DF: CNPq, 1990.

COHEN, I. The Newtonian Revolution. Cambrige: Cambrige University Press, 1983.

COHEN, I. B. e WESTFALL, R. S. (organizadores). Newton: textos, antecedentes, comentários. Rio de Janeiro: Contraponto; EDUERJ, 2002.

CRUZ, Ana Lúcia Rocha Barbalho; PEREIRA, Magnus Roberto de Mello. Ciência, identidade e quotidiano. Alguns aspectos da presença de estudantes brasileiros na Universidade de Coimbra, na conjuntura final do período colonial. Revista de História da Sociedade e da Cultura, 9 (2009). 
COSTA, J. Cruz. Contribuição à História das Ideias no Brasil. O desenvolvimento da filosofia no Brasil e a evolução história nacional). Rio de Janeiro: José Olymplio, 1956.

CUNHA, N. F. Elites e Acadêmicos na Cultura Portuguesa Setecentista. Imprensa Nacional-Casa da Moeda, 2001.

DECOLA, P. Diversité des natures, diversités des cultures. Montrouge: Bayard, 2010.

DIAS, José Sebastião da Silva. Portugal e a cultura européia (séculos XVI e XVIII). In: Biblos, Vol. XXVIII, 1953.

DIAS, Maria Odila Leite da Silva. Aspectos da Ilustração no Brasil. Revista do Instituto Histórico e Geográfico Brasileiro, n. 278, 1968.

A Interiorização da Metrópole (1808 - 1853). IN: MOTA, C. G. (org.). Dimensões. São Paulo: Perspectiva, 1972.

DOMINGUES, Francisco Contente. Ilustração e Catolicismo. Teodoro de Almeida. Lisboa, Colibri: 1994.

DOMINGUES, H. M. B.; GLICK, T.; SÁ, M. R. (orgs.). A recepção do darwinismo no Brasil. Rio de Janeiro: Editora Fiocruz, 2003.

DUTRA, José Soares. Cairu. Rio de Janeiro, 1943.

EAMON, W. Science and the secrets of nature. Princenton: Princenton University Press, 1994.

FALCON, Francisco J. Calazans. A Época Pombalina: Política Econômica e Monarquia Ilustrada. São Paulo: Editora Ática, 1982.

FENELON, Dea Ribeiro. Cairu e Hamilton: um estudo comparativo. Belo Horizonte: UFMG, 1973.

FONSECA, Maria Rachel Fróes da. As "Conferências Populaes da Glória": a divulgação do saber científico. História, Ciências, Saúde - Manguinhos, vol. 2, no 3 . Rio de Janeiro: Novembro, 1996. Rio de Janeiro, v. 11, n. 3,Dec. 2004.

FONSECA, M. R. F.; LOPES, M. M.; VARELA, A. G. As atividades do naturalista José Bonifácio de Andrada e Silva em sua 'fase portuguesa' (1780-1819). 
FORCE, James E.; POPKIN, Richard H. Essays on the context, nature, and influence of Isaac Newton's theology. Dordrecht/Boston/London: Kluwer Academic Publishers, 1990.

FONTANA, J. A história dos homens. Bauru, SP: EDUSC, 2004.

FRANCO, A. A. de M., O visconde de Cairu. IN: Digesto Econômico. Agosto de 1947.

FRANCO, M. S. de C. As idéias estão no lugar. IN: Caderno de Debates, no 1, p. 61 - 64. São Paulo: Brasiliense, 1976.

FREITAS, Marcus Vinícius. Chales Frederick Hartt, um naturalista no império de Pedro II. Belo Horizonte: Editora da UFMG, 2002.

FRIEIRO, Eduardo. O Diabo na livraria do Cônego. Belo Horizonte, 1945.

FURTADO, C. Formação econômica do Brasil, 5. ed., Rio de Janeiro: Editora Fundo de Cultura, 1963. (1ª edição: 1959).

GADAMER, Hans-Georg. Verdade e método. Traços fundamentais de uma hermenêutica filosófica. Petrópolis: Vozes, 1997.

GAUER, Ruth Maria C. A construção do Estado-nação no Brasil. A contribuição dos egressos de Coimbra. Curitiba: Juruá, 2001.

GAY, P. The Enlightenment: an interpretation. The Rise of Modern Paganism. New York: Norton, 1995.

GUIMARÃES, L. M. P.: Memórias partilhadas: os relatos dos viajantes oitocentistas e a idéia de "civilização do cacau". História, Ciências, Saúde - Manguinhos, vol. VIII (suplemento), 1059-70, 2001.

GUNTAU, Martin. 'José Bonifácio de Andrada e Silva. Estudos e trabalhos científicos na Europa Central'. Em Silvia F. de Mendonça Figueirôa (org.). Um olhar sobre o passado: história das ciências na América Latina. Campinas, Unicamp, 2000.

HAMPSON, Norman. O Iluminismo. Lisboa: Ulisseia, 1968.

HANKINS, Thomas L. Science and Enlightenment. Cambridge: Cambridge University Press, 1985. 
HAZARD, Paul. A crise da consciência européia. Lisboa: Cosmos, 1948. . Pensamento europeu no século XVIII. Lisboa: Presença, 1974.

HOLANDA, Sérgio Buarque de (direção). História Geral da Civilização Brasileira. São Paulo: DIFEL, 1985.

. Raízes de Brasil. São Paulo: Companhia das Letras, 1995.

ISRAEL, J. Radical Enlightenment: Philosophy and the Making of Modernity (1650 1750). New York: Oxford University Press, 2001.

. Enlightenment Contested. Modernity, and the Emancipation of Man (1670 1752). New York: Oxford University Press, 2006.

JANCSÓ, István. Na Bahia, Contra o Império: História do Ensaio de Sedição de 1798. São Paulo: HUCITEC; Salvador: EDUFBA, 1996.

KIRSCHNER, Tereza Cristina. Ecos do iluminismo escocês no Brasil. IN: BOTELHO, Cléria (org.). Um passeio com Clio. Brasília: Paralelo 15, 2002.

Elites ilustradas na Bahia do final do período colonial. Trajetórias, conflitos, acomodações. Atas do II Colóquio História Social das Elites. Instituto de Ciências Sociais, Universidade de Lisboa, 2003.

. Entre a lei e o rei. Natureza, legislação ilustrada e conflitos no final do período colonial. Textos de História, nº 1-2, 2003.

José da Silva Lisboa, Visconde de Cairu. Itinerário de um ilustrado lusobrasileiro. São Paulo: Alameda; Belo Horizonte: PUC-Minas, 2009.

KIRSCHNER, Tereza Cristina e LACERDA, Sonia. Tradição intelectual e espaços historiográficos ou por que dar atenção aos textos clássicos. IN: LOPES, Marcos (org.). Grandes nomes da história intelectual. São Paulo: Contexto, 2003.

KOSELLEK, R. Futuro Passado: contribuição à semântica dos tempos históricos. Rio de Janeiro: Contraponto; Ed. PUC-Rio, 2006. 
KURY, L. Homens de ciência no Brasil: impérios coloniais e circulação de informações (1780-1810). Rio de Janeiro: História, Ciências, Saúde-Manguinhos 11, 2004, 234-255.

LASLETT, P. “Introdução". IN: Locke, J. Dois Tratados sobre o Governo. São Paulo: Martins Fontes, 2001 [1 $1^{\mathrm{a}}$ edição: 1962].

LENOBLE, Robert. História da Idéia de Natureza. Rio de Janeiro: Edições70, 1990.

LIMA, Alceu do Amoroso. Época, Vida e Obra de Cairu. IN: José da Silva Lisboa Princípios de Economia Política. 2a ed. Rio de Janeiro, 1956.

LISBOA, E. (coord.). Dicionário cronológico de autores portugueses. Instituto Português do Livro Europa-América, 1985.

LISBOA, José da Silva. Princípios de Economia Política para servir de introdução à teoria Econômica do autor dos Princípios de Direito Mercantil. Lisboa: Impressão Régia, 1804.

. Estudos do bem comum e economia politica ou ciência das leias naturais e civis de animar e dirigir a geral indústria e promover a riqueza nacional $e$ prosperidade do Estado. Rio de Janeiro: Impressão Régia, 1819-1820.

. Constituição Moral de deveres do cidadão com exposição da moral pública conforme o espírito da constituição do império. Rio de Janeiro: Typographia Nacional, 1824-1825.

LOSEE, John. Introdução Histórica à Filosofia da Ciência. Col. O Homem e a Ciência. Vol.5. São Paulo; Edusp/Itatiaia, 1979.

MACEDO, Jorge Borges de. O Bloqueio Continental: economia e guerra peninsular. Lisboa: Gradiva, 1990.

MARTINS, Wilson. História da inteligência brasileira. São Paulo: T. A. Queiroz, 1992.

MATOSO, José. História de Portugal. Lisboa: Editorial Estampa, 1993.

MATTOS. Ilmar Rohloff de. O tempo saquarema. A formação do Estado imperial. Rio de Janeiro: Access, 1994. 
MAXWELL, K. A Devassa da Devassa, A Inconfidência Mineira, Brasil e Portugal (1750 - 1808). Rio de Janeiro: Paz e Terra, 2000.

MELCHIOR, Elísio de Oliveira. Visconde de Cairu, sua vida e sua obra. Rio de Janeiro, 1959.

MELLO, J. M. C. O capitalismo tardio. São Paulo: Brasiliense, 1987.

MONTEIRO, Pedro Meira. Um moralista nos trópicos: o visconde de Cairu e o Duque de la Rochefoucauld. São Paulo: Fapesp / Boitempo Editorial, 2004.

MORAES, Vilhena. O perfil de Cairu. Rio de Janeiro, 1968.

MUAZE. Mariana. O Vale do Paraíba Fluminense e a dinâmica imperial.

MUNTEAL, Oswaldo. Todo um mundo a reformar. Intelectuais, cultura ilustrada e estabelecimentos científicos na América Portuguesa 1779 - 1808. Anais do Museu Histórico Nacional. Rio de Janeiro, v. 29, 1997.

NAXARA, Márcia Regina Capelari. Cientificismo e sensibilidade romântica: em busca de um sentido explicativo para o Brasil no século XIX. Brasília: Editora Universidade de Brasília, 2004.

NEVES, Lúcia Maria Bastos Pereira das. Corcundas e Constitucionais: a cultura política da independência (1820 - 1822). Rio de Janeiro: Revan/FAPERJ, 2003. Intelectuais brasileiros nos oitocentos: a constituição de uma "família" sob a proteção do poder imperial (1821 - 1838). IN: PRADO, Maria Emília (org.). $O$ Estado como vocação. Rio de Janeiro: Access, 1999.

NEWTON, Isaac. Princípios matemáticos de filosofia natural. São Paulo: Edusp, 2002. Óptica. São Paulo: EDUSP, 1996.

NOVAIS, Fernando A. Portugal e Brasil na Crise do Antigo Sistema Colonial (17771808). $3^{a}$ edição. São Paulo: Hucitec, 1985.

O reformismo ilustrado luso-brasileiro: alguns aspectos. IN: Aproximações. Estudos de história e historiografia. São Paulo: COSACNAIFY, s/d. Publicado originalmente na Revista Brasileira de História, n. 7, p. 105-108, 1984. 
NOVAIS, F. A.; ARRUDA, J. J. de Andrade. Prometeus e Atlantes na forja da nação. Introdução. IN: LISBOA, José da Silva. Observações sobre a franqueza da indústria, e estabelecimento de fábricas no Brasil. Brasília: Senado Federal, 1999.

OLIVEIRA, Daniel de Lara. Ciência moderna e newtonianismo no projeto pedagógico de Luís António Verney. São Paulo: Todas as Musas, 2013.

OLIVEIRA, J.C. D.João VI adorador do Deus das ciências?. A constituição da cultura científica no Brasil (1808-1821). Rio de Janeiro: e-papers, 2005.

PAGDEN, A. La ilustración y sus enemigos. Dos ensayos sobre los orígenes de la modernidad. Barcelona: Ediciones Península, 2002.

PAIM, Antonio. Cairu e o Liberalismo Econômico. Rio de Janeiro: Tempo Brasileiro, 1968.

PAULA, L. Nogueira de. Introdução. IN: Lisboa, José da Silva. Princípios de Economia Política. Rio de Janeiro, 1956.

POCOCK, J.G.A. The History of Political Thought a Methodological Enquire, 1962.

PRAÇA, J. J. L. História da Filosofia em Portugal. Lisboa: Guimarães Editora, 1988.

ROCHA, Antonio Penalves. A economia política na sociedade escravista. São Paulo: Depto. de História - FFLCH - USP / Hucitec, 1996.

(Org. e Introd.). Visconde de Cairu (1756 - 1835). São Paulo: Editora 34, 2001

A economia política na desagregação de império português. IN: CARDOSO, José Luis (org.). A economia política e os dilemas do Impériobrasileiro (1790 - 1822). Lisboa: Comissão para comemorações dos Descobrimentos Portugueses, 2001.

ROCHA, Antonio Penalves. A escravidão na economia política. IN: Revista História, São Paulo, 120, p. 97-108, Jan/Jul 1989.

RODRIGUES, M. A. A Universidade de Coimbra e a elite intelectual brasileira na última fase do período colonial período colonial. IN: Revista de História das Idéias, v. $12,1990$. 
ROSSI, Paolo. O nascimento da ciência moderna na Europa. Bauru: EDUSC, 2001.

. A Ciência e a Filosofia dos modernos. Campinas, UNESP, 1992.

RUIVO, Maria da Conceição. O Iluminismo e a Cultura Científica. In: Catálogo da Exposição Laboratório do Mundo: idéias e saberes do século XVIII. São Paulo: Imprensa Oficial, 2004.

RICOEUR, P. Tempo e narrativa. Campinas: Papirus, 1997.

SANSON, João Rogério; SPAIZMANN, Gabriela. Cairu e o liberalismo smithiano na Abertura dos Portos. IN: Análise. Vol. 17, nº 2. Porto Alegre, 2006.

SCHWARTZ, Stuart B. Burocracia e sociedade no Brasil Colonial: a Suprema Corte da Bahia e seus juízes, 1609 - 1751. São Paulo: Perspectiva, 1987.

SILVA, Beatriz Nizza. A Cultura Brasileira: da reforma da Universidade à independência do Brasil. Lisboa: Editorial Estampa, 1999.

. O Império Luso Brasileiro, 1750 - 1822. Lisboa: Editorial Estampa, 1986.

. Linguagem, cultura e sociedade. O Rio de Janeiro 1808 a 1821. Tese de Livre Docência. 1993. FFLCH - USP.

. Livro e sociedade no Rio de Janeiro. IN: Revista de Hstória. SP nº 94, 1973.

SILVA, João Manuel Pereira. Plutarco Brasileiro. Rio de Janeiro, 1947.

SILVEIRA, Zenith Mendes da. A originalidade do liberalismo brasileiro. IN: O Estado de São Paulo, 8/07/1956.

SKINNER, Q. Meaning and Understanding in the History of Ideas. IN: History and Theory $8,1969$.

. Interpretación, racionalidae y verdad. IN: SKINNER, Q. Lenguaje, política e história. Bernal: Univ. Nacional de Quilmes, 2007.

. Significado y comprensión en la historia de las ideas. IN: SKINNER, Q. Lenguaje, política e história. Bernal: Univ. Nacional de Quilmes, 2007.

. Motivos, intenciones e interpretación. IN: SKINNER, Q. Lenguaje, Política e História. Bernal: Univ. Nacional de Quilmes, 2007. 
Interpretación y comprensión en los atos de habla. IN: SKINNER, Q. Lenguaje, política e história. Bernal: Univ. Nacional de Quilmes, 2007.

SMITH, Adam. Investigação sobre a natureza e as causas da riqueza das nações. $3^{\mathrm{a}}$ edição. São Paulo: Abril Cultural, 1984. . Investigação sobre a natureza e as causas da riqueza das nações. $3^{\mathrm{a}}$ edição. São Paulo: Nova Cultural, 1988.

SOUSA, Octavio Tarquínio de. História dos fundadores do Império do Brasil: José Bonifácio de Andrada e Silva, vol. I. Rio de Janeiro, José Olympio, 1957.

STEIN, Stanley. Grandeza e Decadência do Café no vale do Paraíba. São Paulo: Brasiliense, 1958.

STEPAN, Nancy. Gênese e Evolução da Ciência Brasileira. Rio de Janeiro: Arte Nova, 1976.

STOCZKOWSKI, Wiktor. Anthropologies rédemptrices. Le monde selon Lévi-Strauss [Antropologias redentoras. O mundo segundo Lévi-Strauss]. Paris: Hermann Éditeurs, 2008.

VAINFAS, Ronaldo (org.). Dicionário do Brasil imperial. Rio de Janeiro: Objetiva, 2002.

VARNHANGEM, Francisco Adolfo. História Geral do Brasil [1853-1857]. $7^{\mathrm{a}}$ ed. São Paulo: Melhoramentos, 1962, 5v.

História da independência do Brasil até o reconhecimento pela antiga metrópole, compreendendo separadamente a dos sucessos ocorridos em algumas províncias até essa data [1875]. $3^{\text {a }}$ ed. São Paulo: Melhoramentos, 1957.

VIANNA, Hélio. Contribuição à história da imprensa brasileira (1812-1869). Rio de Janeiro: Imprensa Nacional, 1945.

VILHENA, Luís dos Santos, Cartas de Vilhena: Notícias Soteropolitanas e Brasílicas. Salvador: Imprensa Oficial do Estado, 1921. 
VILlALTA, Luis Carlos. Reformismo ilustrado, censura e práticas de leitura: usos do livros na América portuguesa. Tese de doutorado. Universidade de São Paulo, 1999.

VOVELLE, Michel (org.). O Homem do Iluminismo. Lisboa: Editorial Presença, 1997.

WESTFALL, R. The Construction of Modern Science. Mechanisms and Mechanics. Cambridge: Cambridge University Press, 1977.

WEFFORT, F. Formação do pensamento político brasileiro. Idéias e personagens. São Paulo: Ática, 2006. 